\title{
VIOLENCIA PERFORMATIVA CONTRA LAS AGRESIONES MACHISTAS EN EUSKAL HERRIA
}

\author{
ARRATE GUTIERREZ GOMEZ \\ Supervisora Principal: CARMEN GREGORIO GIL \\ Directora de Apoyo: Suzanne Clisby (University of Hull)
}

Universidad de Granada

Instituto Universitario de Investigación de

Estudios de las Mujeres y de Género

Septiembre 2017

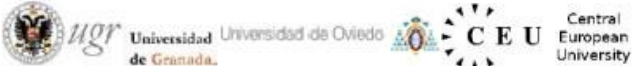




\begin{abstract}
Since July 2014 certain feminist groups within the Basque feminist movement have been carrying out protests which aim to denounce sexual harassment through the use of what Rhodes (2007) and Manzi (2014) term "performative violence", or "performative techniques of violence" as the transfeminist group Medeak names it. As part of my work, I made an attempt to track the trajectory of those protests which avail of performative violence since the first one took place in Iruña in 2014 , as a pre- popular party protest held during the night. By doing this, I identify a relative continuum throughout the different local feminist groups in regards to their use of performative violence. However, this has not occured due to official or organised campaigns or correspondance .

These feminist protests have stirred heated debates, and have been met by critical reactions from diverse sectors within Basque society. I argue that the discomfort borne from these protests has significant political potential in its capacity to affect social change with regards sexual violence, and gender inequality more broadly. Specifically, I argue that the efficacy of these protests to enact direct action lies within the use and subsequent reappropriation of performative techniques of violence. Therefore, I aim to explore the ways in which the performance, aesthetics and politics surrounding these protests intersect with the promotion of feminist self-defence, as well as reinforcing a significant critique of nationalist, androcentric, and masculinist gender constructions and political discourses within the Basque context.
\end{abstract}




\section{ABSTRACT}

Desde julio de 2014 ciertos grupos del Movimiento feminista vasco han estado llevando a cabo protestas que tienen como objetivo denunciar y protestar en contra de las agresiones sexuales a través del empleo de lo que Rhodes (2007) y Manzi (2014) denominan "violencia performativa" o "técnicas performativas de la violencia" como las denomina el grupo transfeminista Medeak. Como parte de mi trabajo, he tratado de trazar la trayectoria de las protestas que hacen uso de violencia performativa desde la primera experiencia que se dio lugar en Iruña en 2014 como una manifestación nocturna pre- fiestas, pre- Sanfermines. Al hacer este rastreo, identifico un relativo continuum a través de los distintos grupos locales en relación al empleo de violencia performativa, a pesar de que esto no ocurre debido a una campaña oficial u organizada, sino de forma espontánea.

Han surgido acalorados debates y críticas en torno al fenómeno de estas protestas feministas, en diferentes sectores de la sociedad vasca. En el presente trabajo argumento que la incomodidad surgida por estas manifestaciones tienen significante potencial político en cuanto a su capacidad para crear cambio social en relación a la violencia sexual en particular, y respecto a la desigualdad de género en general. Concretamente, argumento que la eficacia de estas protestas que llevan a cabo acción directa se basa en el uso y reapropiación de técnicas performativas de la violencia. De esta manera, tengo como objetivo explorar las formas en las que las performance, la estética y las políticas de las protestas intersectan con la promoción de la autodefensa feminista con una critica a las construcciones de género, así como refuerzan una significante critica a discursos políticos nacionalistas, androcéntricos y masculinistas en el contexto vasco. 


\section{AGRADECIMIENTOS}

Primero de todo, debo agradecer a mis gurasos Karmele y Tomás por su sincero apoyo, educación y amor. También soy muy afortunada de haber compartido los dos años del máster (y los que quedan) con mis compañeras del programa Gemma, lo cual ha sido infinitamente enriquecedor y una experiencia transformadora. Specally, I would like to thank Danielle for her constant support, advise and encouragement and my soulmate Giselle for such a beautiful frienship. Also, thank you Mirel and Asma for delicious teas with cookies (cookies mainly for me) and its corresponding laughter, debates and shared frustrations. Cristina, gracias por ser mi diccionario andante y los paseos por Hull. Sihame, Giulia, Livia, Rachana, Barbara, Joana, Elena, Bea, Alice, Omar, Anna, Karina, Alberto and Valentina for inspiring me in so many different ways.

Ezinbestean, lan honetarako harremanean egondako euskal aktibista feministak gogora ekarri nahi ditut hemen, baita Farruka, Medeak, Arabako Emakumeen Asanblea eta OihuK kolektiboak ere. Ez bakarrik eskerrak emateko, baizik eta haien lan, aktibismo eta bizitza eraldatzaileen aldeko mirespena sentitzen baitut. Haien denbora, kemena, hausnarketak eta grina partekatu dute nirekin, motibazio bultzada oso garrantzitsua izanik.

Por último, pero no menos, me gustaría agradecer a mi supervisora Carmen Gregorio Gil, de quien subrayaría y me llevo su "lectura activa", los ánimos y su acompañamiento como compañera en vez de desde un posicionamiento jerárquico. Así mismo, también agradezco a Suzanne Clisby su ayuda. 
ÍNDICE

1. CONSTRUCCIÓN DEL PROBLEMA DE INVESTIGACIÓN: La Violencia

Performativa del Miedo del Movimiento Feminista Vasco

1.1. Trazando el Recorrido de las Manifestaciones "EI Miedo Va a Cambiar de Bando"

1.2. El Interés de mi investigación ............................................................ 8

2. METODOLOGÍA y PROCESO METODOLÓGICO ............................................. 10

2.1. El Desarrollo del Planteamiento del Proyecto: Un Proceso de Diálogo

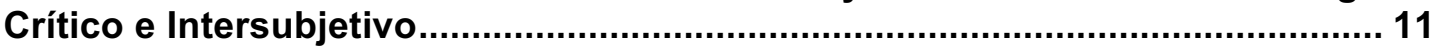

2.2. Las Entrevistas: Representación, Autoría y Temores ............................ 14

2.3. Técnicas de Investigación: entrevista dialógica, análisis discursivo y

observación participante.

2.4. Saliendo del anonimato, exposición de mi posición en la investigación

20

2.5. Objetivos de la Investigación

3. Contexto. LA CODIFICACION DEL ESPACIO PUBLICO- POLITICO DEL MLNV

A TRAVÉS DEL EUSKO GUDARIA .................................................................. 24

3.1. MLNV: nacionalismo, conflicto armado y políticas de género................25

3.2. El Militante, Guerrero y Político, es hombre ............................................ 27

3.3. Marco simbólico- ritual del MLNV: portador y reproductor de políticas

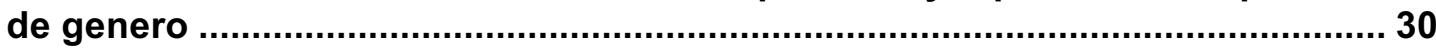

4. VIOLENCIA PERFORMATIVA y TÉCNICAS PERFORMATIVAS DE LA

VIOLENCIA.

4.1. Sobre violencia performativa y técnicas performativas de la violencia 33

4.2. Violencia performativa y género en acción, casos destacables ............. 37

4.3. Símbolos en la violencia performativa. Los casos del pasamontañas en

las Pussy Riot y las Zapatistas ..................................................................... 43

5. AGENCIACIÓN DE TÉCNICAS PERFORMATIVAS DE LA VIOLENCIA ...........47

5.1. Pensamiento transfeminista y bollero y acción directa: las políticas desde dónde surge la estética de la violencia como estrategia política ........... 47

5.2. Agenciación del miedo y técnicas performativas de la violencia como

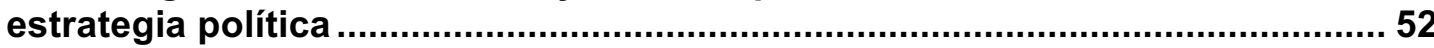

5.3. Performance del miedo y violencia simbólica...............................................54

5.3.1. El símbolo del pasamontañas: icono de continuidad y legitimación del MFV 57

5.4. Poder performativo y género 60

5.4.1. Cuando mujeres ejercen violencia simbólica de noche: contradicción

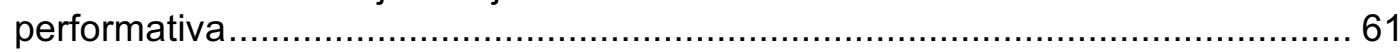

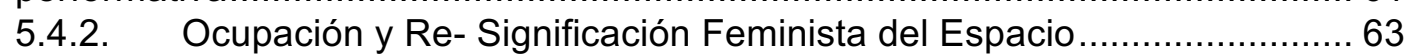

5.5. Violencia Performativa: Incomodidad Multidireccional ..........................65 65

6. SITUANDO LA VIOLENCIA PERFORMATIVA EN EUSKAL HERRIA: NACIONALISMO, GÉNERO Y LAS TÉCNICAS PERFORMATIVAS DE LA VIOLENCIA DEL MFV

6.1. La Eusko Gudari Femenina: una Contradicción Performativa de las

Políticas de Género del MLNV........................................................................ 70

6.2. Debate feminista sobre imitación o apropiación de las "herramientas del amo"

6.3. El poder de las técnicas performativas de la violencia y re-apropiación

símbolos y discursos culturales: sacar a la luz debates en los márgenes ...... 76

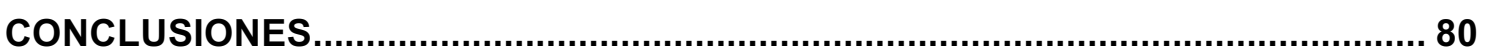

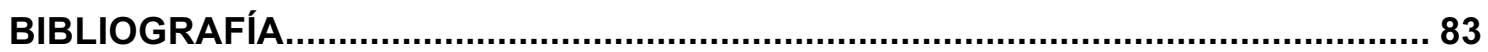





\section{CONSTRUCCIÓN DEL PROBLEMA DE INVESTIGACIÓN: La Violencia Performativa del Miedo del Movimiento Feminista Vasco}

"El miedo va a cambiar de bando", "Matxete al matxote"," "Machistas, cabrones, a los tiburones", "Pienso y respondo, así que estorbo", "Matxirulo vamos a por ti", "Ante un Agresor, Cóctel Molotov", "Ni sumisas, ni pasivas; autónomas y guerreras", "Polla violadora a la licuadora", "Erasorik ez erantzunik gabe/

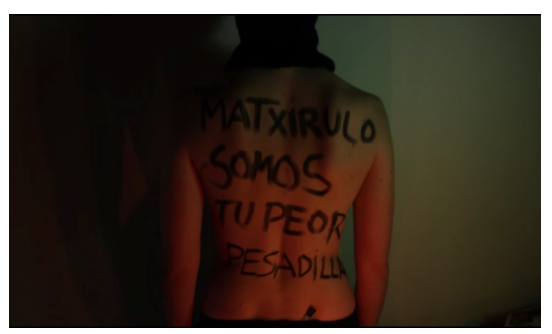
no habrá agresión sin respuesta", "si nos tocan a una nos tocan a todas", "Jai giroan matxirulorik ez/ en ambiente festivo, machirulos no", "babosos fuera”, "¡Cuidado! Acosar no es ligar", "pulpos fuera", "Gaua eta jaiak gureak dira/ La noche y las fiestas son nuestras". Estos lemas combatientes, sin remordimientos ni concesiones, argumentan y promueven la respuesta ante agresiones machistas, sin excluir el enfrentamiento y la acción directa. Bajo el lema central de "el miedo va a cambiar de bando", el Movimiento Feminista Vasco se autoorganiza a través de Euskal Herria para protestar en contra de agresiones machistas, especialmente contra aquellas que ocurren en los ambientes de fiesta en los que bajo el pretexto de la euforia festiva y el exceso de alcohol, parece que todo vale. Es ante esta realidad por lo que muchos grupos feministas locales vascos se movilizan.

La lucha por la legitimidad y promoción de la autodefensa feminista constituye una de las principales modalidades estratégicas en contra de la violencia de género en el ámbito de protestas del Movimiento Feminista Vasco (MFV). Aunque las formas y estrategias para responder a las agresiones y violencias machistas son diversas, en el presente trabajo indagaré las protestas que se organizan bajo el lema "El Miedo Va a Cambiar de Bando".

Sugiero que podemos encontrar un continuum en cuanto a lo que el grupo transfeminista Medeak denomina "apropiación de las técnicas performativas de la violencia" (2014: 78; 2015) o lo que también denominaré en el presente trabajo como "violencia performativa" (Manzi, 2014; Rhodes, 2007).

\footnotetext{
${ }^{1}$ Escribir con "tx" lo que en castellano gramaticalmente sería correcto escribir con "ch" no se trata de una errata tipográfica, sino una decisión propia de respetar el resultado del contacto y convivencia de las dos lenguas del sur de Euskal Herria, castellano y euskera, lo cual considero que forma parte de la diversa y cambiante cultura vasca.
} 
Muchas de las manifestaciones bajo e lema de "el miedo va a cambiar de bando" hacen uso de elementos performativos que como indica Zuriñe Rodriguez (2015) evocan los conflictos armados: la capucha, la noche, la vestimenta negra y el fuego.

Imagen 1: Manifestación nocturna 4 Julio de 2014 en Iruña

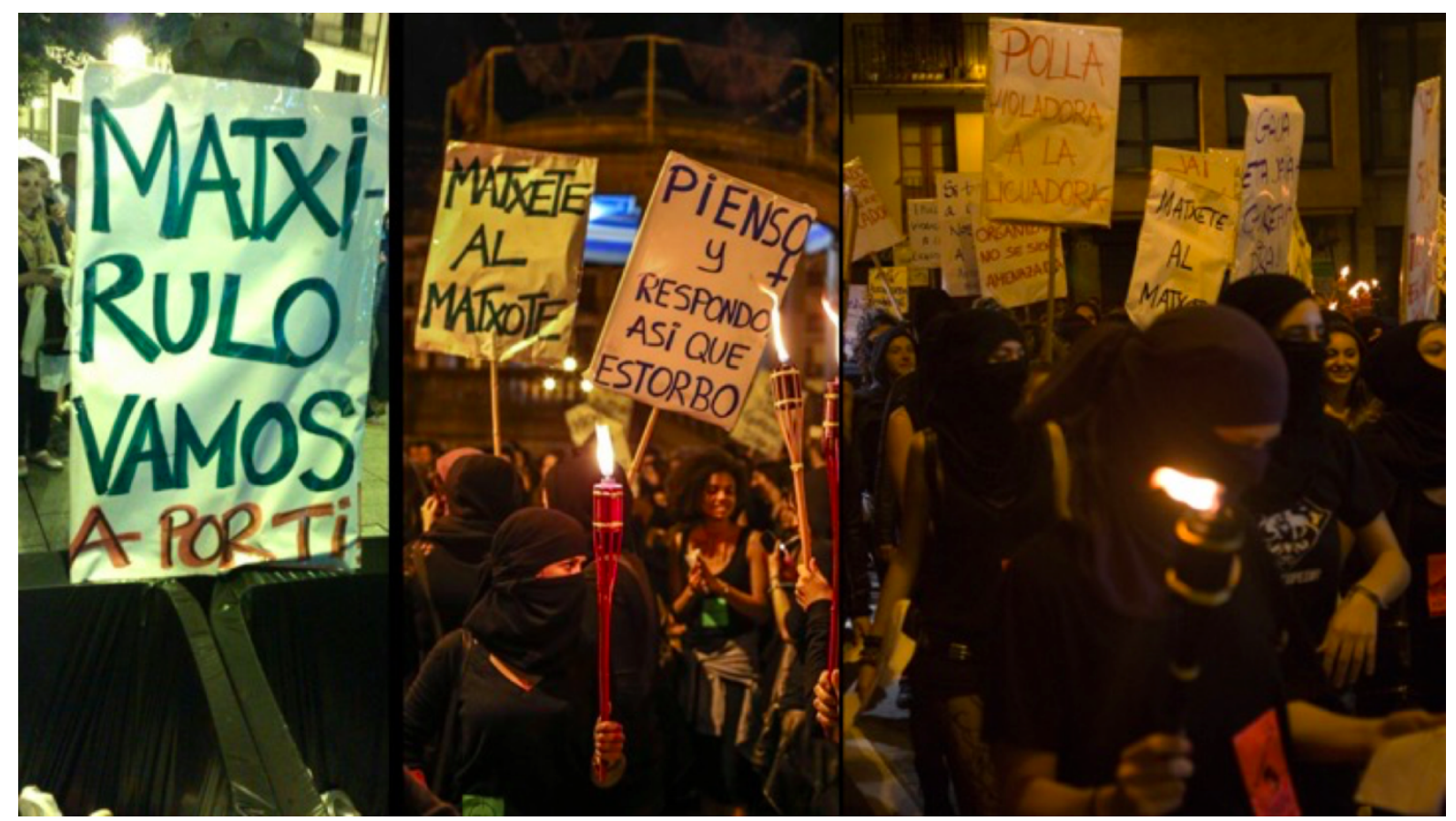

Fuente: Coordinadora Feminista y ekinklick ${ }^{2}$

Como se puede apreciar tanto en la imagen 1 como en la 2, el discurso expresado a través de los lemas, posters y pancartas, va acompañado de vestimenta negra, cara tapada con pasamontañas o similar, antorchas y batukadas. ¿Cuál es la motivación y efecto de esta deliberada decisión estética en cuanto a promover acción política feminista? El grupo donostiarra transfeminista Medeak, describe esta forma y medios de ocupar el espacio como "[reapropiación] de las técnicas performativas de la violencia" (Medeak, 2015). De esta manera, las técnicas performativas escogidas a propósito, producen una estética que hace uso del miedo y violencia simbólica. La transmisión de fuerza, poder y así como infundir miedo caracterizan la estrategia y activismo acogidos premeditadamente por algunos colectivos del MFV para responder a las agresiones sexistas y promover la autodefensa feminista, especialmente, en entornos festivos o fiestas populares.

\footnotetext{
${ }^{2}$ Coordinadora Feminista:http://www.feministas.org/manifestacion-nocturna-4-de-julio.html Ekinklikhttp://ekinklik.org/index.php/es/ultimas-coberturas/472-gaua-eta-jaiak-gureak-diraerasorik-ez-erantzunik-gabe
} 


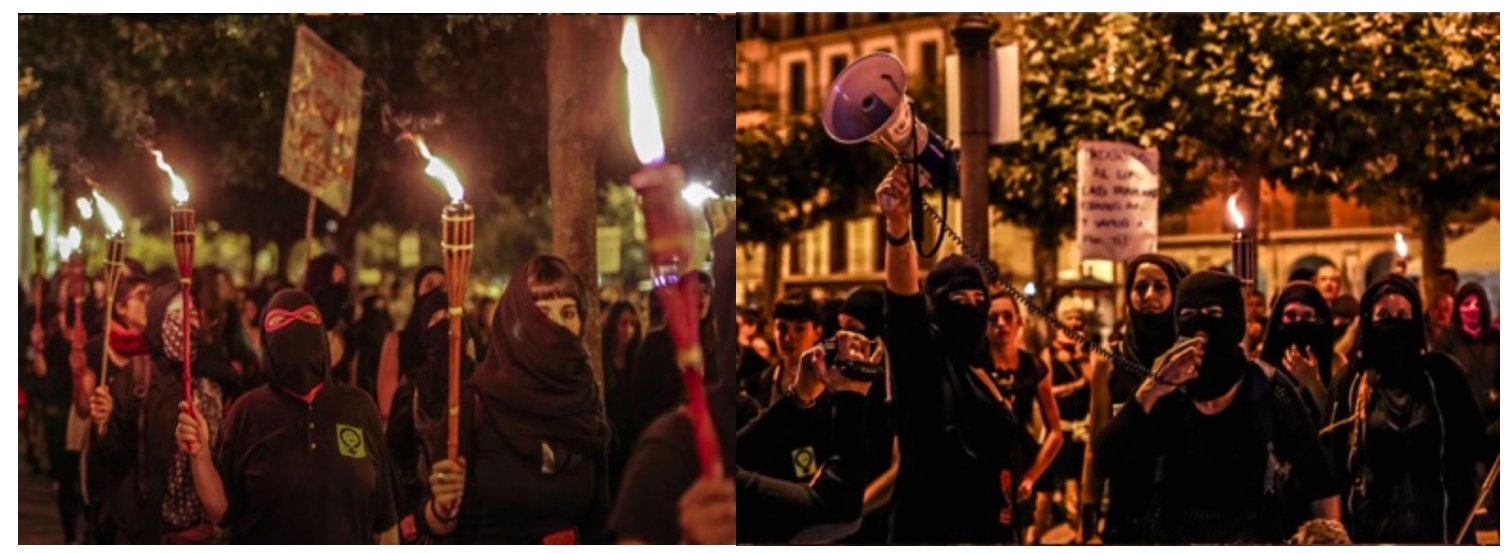

Fuente: Coordinadora Feminista y ekinaklick

La intencionada expresión de violencia utilizando lemas sin remordimientos presentan un punto interesante de análisis para reflexionar sobre la performance en sí misma como estrategia política por un lado; y para analizar cómo el MFV opera dentro de la cultura política vasca del Movimiento de Liberación Nacionalista Vasco y la sociedad vasca en general, por otro lado. Más concretamente, ¿qué significado y qué implicaciones tiene el empleo de una estética y escenificación (performance) que se agencia del miedo y la violencia simbólica? Esto me ha llevado a reflexionar sobre las formas en las que la agenciación de una estética combativa es subversiva o reta las formas dominantes de acción política, y si se reproducen formas masculinistas de representación política.

Debido al uso de símbolos tal y como la capucha, fuego e indumentaria negra, que evocan a la estética que trae a la memoria la estética del MLNV ${ }^{3}$ (Rodriguez Lara, 2015),

${ }^{3}$ En el presente trabajo emplearé el término Movimiento de Liberación Nacional Vasco (MLNV) para hacer referencia a la red organizativa formada por diversos grupos y organizaciones que abarcan desde comisiones de fiestas locales hasta organizaciones políticas. Entiendo que se trata de un grupo heterogéneo, por lo tanto, no trato de representarlo como una categoría uniforme y homogénea.

EI MLNV engloba el movimiento social y político de la Izquierda Abertzale, en otras palabras, este término hace referencia a la red sociopolítica que agrupa a las diversas organizaciones que se basan en la ideología de la IA, es decir, en el proyecto abertzale y socialista. Las organizaciones feministas forman parte de este entramado de organizaciones, junto con organizaciones políticas (Sortu, Bildu y otras), sindicales (LAB), juveniles (Ernai), culturales o ecologistas (Calvo, 2012; Fernández Sobrado y Aierdi Urraza, 1997).

Aunque muy a menudo los términos nacionalismo vasco radical, MLNV e Izquierda Abertzale son usados indistintamente, no tienen exactamente el mismo significado. Nacionalismo vasco radical es el término más amplio y se refiere a un ultranacionalismo independentista que no tiene por qué relacionarse con ETA o ni siquiera con la izquierda.

EI MLNV apareció en la transición, concretamente empezó a ser utilizada a partir de 1985 (Egaña, 1996), mientras que la IA hace referencia al proyecto nacionalista que surgió a partir de los 50, y que aunque originalmente ETA era la única organización que lo formaba, especialmente a partir de la transición se diversificó mucho, llegando al punto de no compartir métodos (Rafael Leonisio Calvo, 2012).

El término Izquierda Abertzale es empleado de forma diferente por los actores y organizaciones de la misma, sin embargo. La propia Ezker Abertzale hace referencia a sí misma como "el movimiento político revolucionario nacido para alcanzar el objetivo de la liberación nacional y 
considero relevante hacer una breve mención al entorno socio político y cultural en el cual estas manifestaciones se dan. Si consideramos los movimientos sociales como un proceso de construcción social que surge y se desarrolla en un contexto cultural y sociopolítico concreto (Fernández Sobrado y Aierdi Urraza, 1997), el análisis del MFV quedaría incompleto si no lo situamos dentro del marco dominante de protesta o el master protestframe, concretamente, el MLNV, ya que según Fernández Sobrado y Aierdi Urraza (1997), la participación de un movimiento social dentro de un marco de protesta dominante, influencia sus fines, estrategias e inter- organización; así como en la percepción que habrá de las mismas. Basándome en esto, considero relevante y necesario contextualizar y preguntar qué relación puede haber entre los actos performativos descritos anteriormente con el MLNV en general, y cómo se negocian.

\subsection{Trazando el Recorrido de las Manifestaciones "EI Miedo Va a Cambiar de Bando"}

El colectivo Farrukas (2016) hace referencia al empleo de los pasamontañas, vestimenta negra y lemas combativos por diversos grupos o colectivos de localidades vascas como "contagio de capuchas" (Farrukas, 2016). Y es precisamente este "contagio" el cual yo identifiqué el verano de 2016 durante una manifestación en contra de una agresión machista: percibí que esta manifestación de alguna manera formaba parte de una continuidad dentro del MFV. Aunque las organizadoras de la manifestación no propusieron el uso de pasamontañas o vestimenta negra, detecté que el objetivo de la manifestación era subrayar la postura de hartazgo y rabia ante las violencias machistas, y así propuesieron la manifestación, como se puede observar en la siguiente cita:

"FRENTE A LAS VIOLACIONES Y AGRESIONES MACHISTAS, ¡MOVILÍZATE!

Este miércoles, 27 de julio, a las 19:30 en Telletxe haremos una rueda de prensa masiva y movilización ruidosa.

Ven con cacharros que hagan ruido,

visibilicemos LA RABIA QUE SENTIMOS,

reivindiquemos LA LIBERTAD QUE NOS CORRESPONDE!

LAS CALLES, LAS NOCHES, LAS PLAZAS, LAS FIESTAS... TAMBIÉN SON NUESTRAS!!" (HaziakTaldeGazte Feminista, 2016).

social de Euskal Herria" (Ezker Abertzale, 2016). Como queda reflejado en un artículo sobre el proceso de reflexión de la IA en un artículo publicado en Larrun (la revista mensual de Argia), los diferentes miembros de la IA utilizan el término para hacer referencia tanto a lo que Rafael Leonisio Calvo considera el término IA estrictamente, como lo que él y otros autores consideran el MLNV. Concretamente, en el artículo mencionado dicen que utilizan el término Izquierda Abertzale en mayúsculas para hacer referencia exclusivamente a las instituciones Sortu, LAB y Ernai, mientras que utilizan el término en minúsculas para referirse a la red organizativa formada por diversos grupos y organizaciones (Arbelaitz 2016), lo que anteriormente he definido como MLNV. 
Además, esta intuición se reforzó al observar la incorporación de los pasamontañas como icono o identificador de la lucha contra las agresiones sexistas:

Imagen 3: Cartel para la manifestación contra una agresión machista en Algorta (2016)

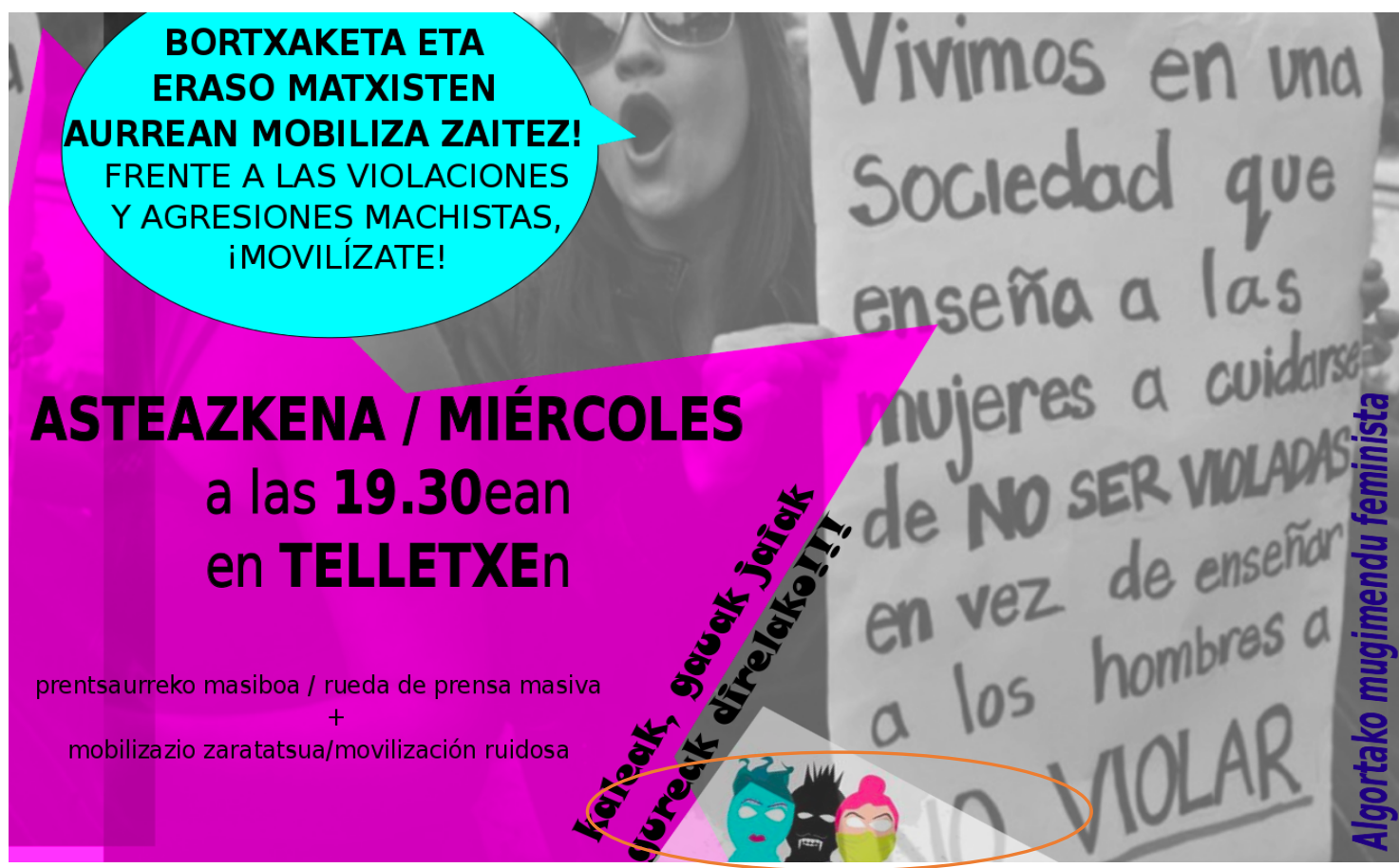

Fuente: Facebook de HaziakTaldeGazte Feminista

Ante esta identificación que me hizo preguntarme si existía un "imperativo performativo" o una campaña acordada para hacer frente a las agresiones machistas en el MFV, comencé a indagar sobre el origen de los pasamontañas y elementos discursivos. Así, comencé a trazar el origen y recorrido de las manifestaciones del MFV que emplean lo que denomino violencia performativa (Rhodes, 2007).

Medeak y Farrukas señalan que esta "continuidad" que yo percibí no ha ocurrido en campañas oficiales o desde una organización jerárquica del movimiento en el que se establece la forma que las protestas deben tomar. Es decir, llevar a cabo la estética de las 'manifestaciones nocturnas' con fuego, capuchas y vestimenta negra no se considera una "campaña" (Farrucas, 2014) y en palabras del grupo Medeak (2015):

"no hay unas jefas mandando organizar estas manifestaciones, surgen y se autoorganizan en ciudades y pueblos de Euskal Herria porque así lo quieren los movimientos locales. En algún caso se puede lanzar como propuesta, pero no es una campaña, ni una estratagema organizada".

A pesar de la aclaración que niega el carácter imperativo del uso de las "técnicas performativas de la violencia", tras haber identificado el contagio, a lo que yo hago referencia como una continuidad en el MFV en cuanto al empleo de violencia performativa como estrategia de acción directa contra agresiones machistas, he tratado de trazar el recorrido de estas manifestaciones en diversas localidades de Euskal Herria, 
desde la primera experiencia en 2014 en la manifestación nocturna pre- sanfermines en Iruña. Así, sugiero que el uso del símbolo de la cabeza con el pasamontañas, la técnicas performativas de la violencia y eslóganes combativos han ido ganando legitimidad a lo largo del MFV y podemos apreciar un continuum en las representaciones de la lucha contra las agresiones machistas en el MFV. Me baso en las experiencias que continuaron y continúan a día de hoy a partir de la primera experiencia de 'manifestación nocturna' en Iruña, a las que corresponden as imágenes 1 y 2.

A través del seguimiento de entrevistas realizadas a diferentes actrices del movimiento feminista vasco y los recursos multimedia online, como Pikara Magazine, he intentado rastrear las protestas que tienen como lema "El miedo va a cambiar de bando" que utilizan simbolismo violento como mecanismo político, ya que sugiero que estas protestas lejos de ser ocasionales, conforman un modelo que se viene conformando por parte de diferentes colectivos del MFV desde el 2014. Como resultado de esta búsqueda y de acuerdo con Medeak (2015), he localizado la primera 'manifestación nocturna' con la estética descrita anteriormente en el 4 de Julio del 2014 en Iruña, año en el que las campañas populares feministas se intensificaron en San Fermines o resultaron especialmente visibles (Cañete, 2014), interesantemente coincidiendo con esa performance simbólica y discursiva agresiva. Junto con las habituales pancartas en contra de las agresiones machistas distribuidas por las calles de la ciudad, la creación de un protocolo de prevención, talleres de autodefensa feminista y un teléfono al que víctimas de agresiones podían acudir, en el año 2014 se llevaron a cabo una concentración y dos manifestaciones el día 4 de julio ${ }^{4}$ : una diurna y otra nocturna. Esta última se convocó por un colectivo autónomo llamado FARRUCAS y recorrió las calles de la ciudad al estilo de "reclama la noche". Más de mil personas, la mayoría mujeres vestidas de negro, encapuchadas y con antorchas, recorrieron las calles del casco viejo bajo el lema "El miedo va a cambiar de bando" (Coordinadora Feminista, 2016) junto con los eslóganes recogidos unos párrafos más arriba.

Después de la inauguración, esta manifestación pre- Sanfermines se ha llevado a cabo en Iruña consecutivamente en los años 2014 , 15, 16 y 17, como se puede observar en el póster de la imagen 4.

\footnotetext{
${ }^{4}$ Esta manifestación fue pre- Sanfermines, en previsión de agresiones machistas que se preveían para las dos próximas semanas, como todos los años en esas fechas. Estas fiestas suelen ser particularmente agresivas en todos los sentidos, y especialmente salvajes en cuanto a agresiones machistas, ya que la filosofía de 'en fiestas todo vale' llega a su punto álgido. Aunque podríamos mencionar muchísimos casos, todos ellos igualmente relevantes, sólo basta recordar a Nagore Laffage que fue asesinada en el chupinazo de los sanfermines de 2008 por José Diego Yllanes, ciertas imágenes particularmente impactantes del año 2013 o la violación grupal de este pasado 7 de julio de 2016 a una chica de 18 años.
} 

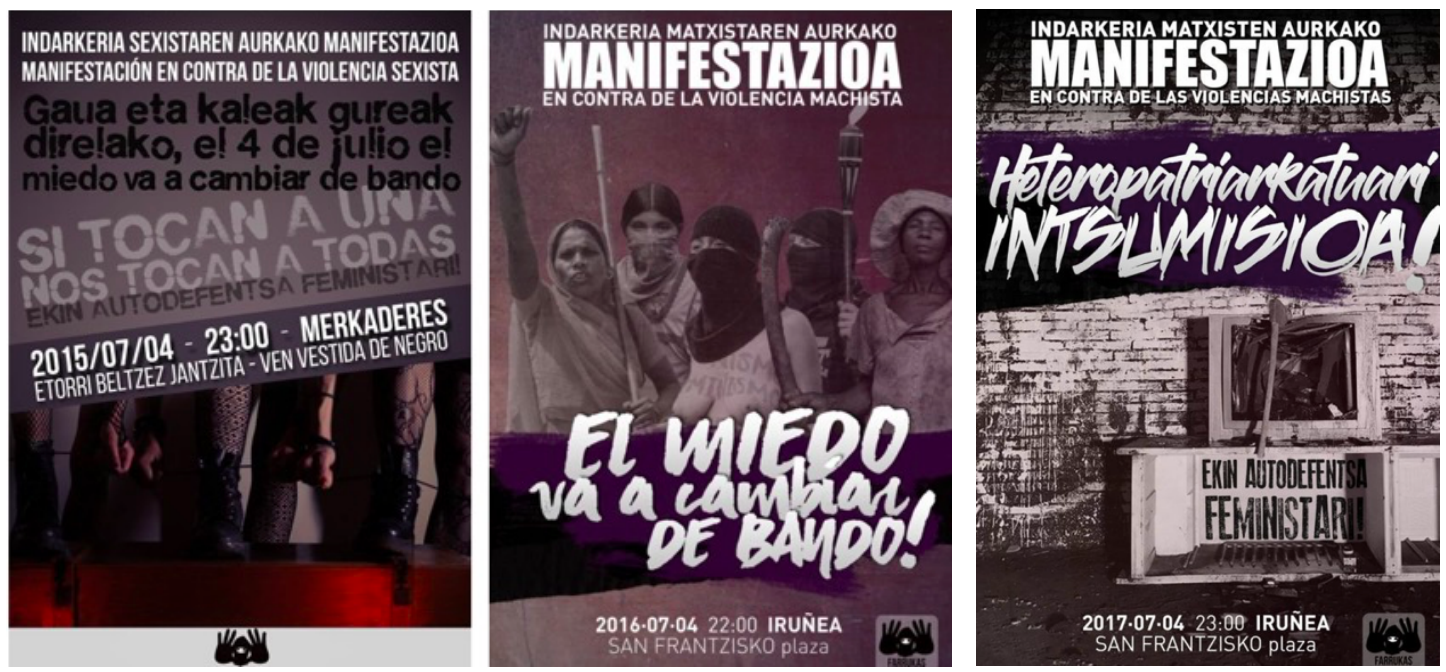

Fuente: Zabala Gonzalez, 2015, Pikarahttp://www.pikaramagazine.com/2015/07/el-miedo-va-acambiar-de-bando/

Como he mencionado, la iniciativa y modelo de manifestación nocturna gustó y no se limitó a esta primera experiencia. Aunque no tengo constancia del año 2014, el año siguiente (2015) manifestaciones nocturnas pre- fiestas siguiendo las mismas pautas fueron llevadas a cabo principalmente en otras ciudades de Euskal Herria: Bilbo y Donostia, y en los siguientes años hasta día de hoy en otras localidades, por ejemplo, el 14 de marzo de 2015 en Hernani ${ }^{5}$ y este 16 de julio de 2017 en el barrio Iretargi de Barakaldo, Bizakaia. Las siguientes imágenes pertenecen a las protestas nocturnas organizadas al comienzo de la semana grande (Aste Nagusia) de Bilbo (Imagen 5) y Donostia en el año 2015 (Imagen 6).

Imagen 5: Manifestación pre- Semana Grande de Bilbo 2015

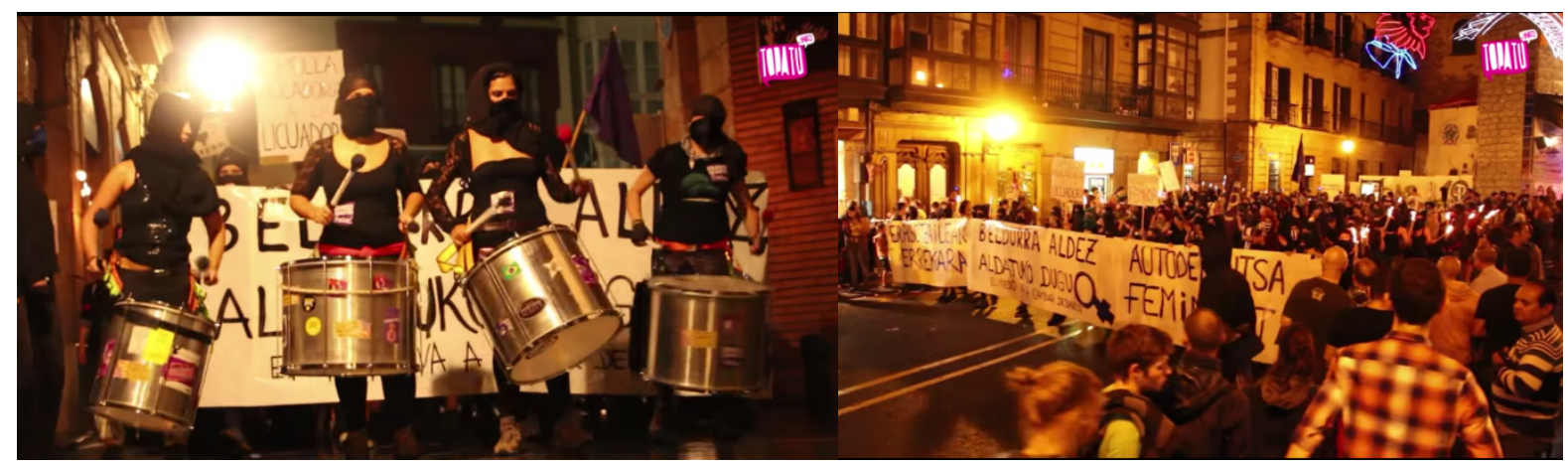

Fuente: Toaptu.info

Al igual que las mujeres vestidas de negro y con pasamontañas salieron a las calles de Bilbo bajo el lema "Eraso sexistarik ez! Beldurra lekuz aldatuko dugu!"/ "¡No a las

\footnotetext{
${ }^{5}$ Llamaron a esta ocupación feminista de las calles "Sagar Moreen Iraultza", la revolución de las manzanas moradas. El enlace del video es el siguiente: https://www.youtube.com/watch?v=yh7f5xU9wpw
} 
agresiones sexistas! ¡El miedo va a cambiar de bando!”, en Donosti también protestaron

y defendieron la autodefensa feminista al grito de "matxismoa sutara!/ ¡El machismo a la hoguera!".

Imagen 6: Manifestación pre- Semana Grande de Donostia 2015

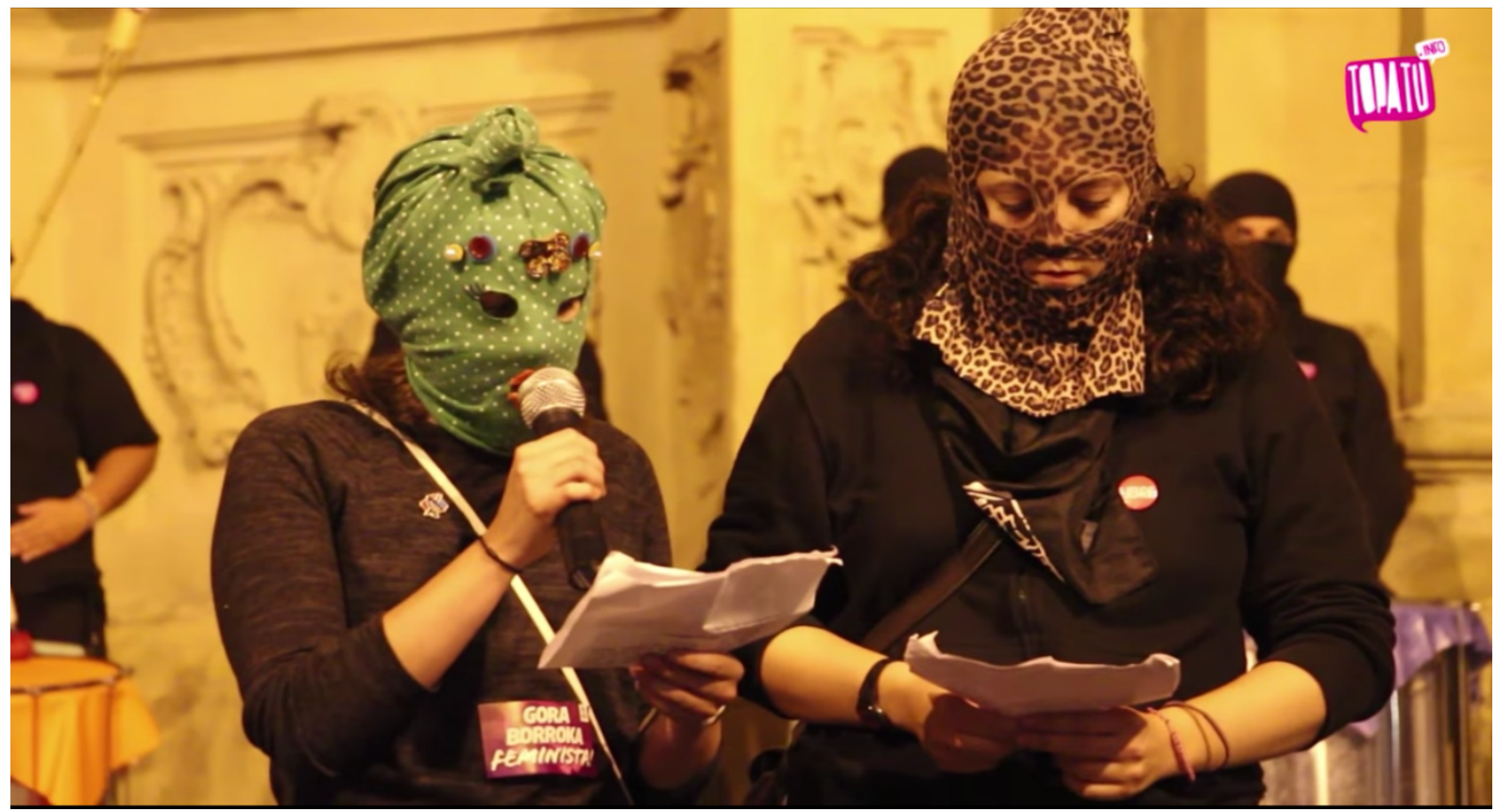

Fuente: Topatu.info

\subsection{El Interés de mi investigación}

¿Por qué esta problemática? Me resulta interesante que estas manifestaciones que hacen uso de lo que llamaré violencia performativa, hayan creado revuelo, incomodidades y ataques en contra del MFV. Entre estos, encontramos el de criminalización del MFV, mediante la denuncia y multa interpuesta a dos activistas feministas gasteiztarras en las fiestas de La Virgen Blanca en 2015 por protestar en contra de un asalto machista durante el 'paseíllo de los blusas' ${ }^{6}$. Los debates acalorados

\footnotetext{
${ }^{6}$ El paseíllo o kalejira de los blusas y las neskas ocupan las calles de Gasteiz del 5 al 9 de agosto, ya que forman una de la actividad festiva principal que se da durante las fiestas de la Virgen Blanca por las diferentes cuadrillas. Durante muchos años, todas las cuadrillas de Blusas y Neskas han estado organizadas bajo la Comisión de Blusas y Neskas de Vitoria- Gasteiz. Sin embargo, 7 cuadrillas de blusas salieron de la comisión y se organizan en un órgano independiente denominado la Federación de Blusas. Esta excesion se debe a que no están de acuerdo con cumplir el protocolo en contra de agresiones sexistas,que entre otras medidas, establece parar el paseíllo para denunciar agresiones sexistas, lo cual fue origen de diversos conflictos que acabaron en la división de las cuadrillas en dos órganos: la comisión, la cual está a favor de luchar en contra de las agresiones machistas, y la Federación, la cual se niega a ello. Esta situación es el final de muchos años de no querer asumir diversas criticas dirigidas al modelo festivo masculinista y resistente en cuanto al integrar medidas en contra de culturas que promueven y legitiman el machismo y sus diversas expresiones, así como las diversas violencias machistas. Para saber más sobre este caso, el cual nos recuerda a otros conflictos en Euskal Herria en torno al modelo festivo tal como el Alarde de Hondarribi, por ejemplo, ver los siguientes
} 
también han llegado a las redes, un ejemplo es el provocado por el artículo de la feminista Itziar Ziga (2015) publicado en el periódico Naiz en el que tachaba a los grupos del MFV que hacen uso de violencia performativa como "hooligans" e insinuando que esta estética es la asimilación de las técnicas de "los 'amos"' (Medeak, 2014: 78). Al mismo tiempo, interesantemente, parte de las incomodidades también han surgido por la relación entre el símbolo del pasamontañas a la lucha armada del MLNV, y considerar esto inapropiado debido al ciclo político actual denominado de "paz".

Mari Luz Esteban (2017) identifica dos factores principales que alimentan las críticas al MFV. Por una parte, la falta de normalización de las actividades publicas de las mujeres y por otra "la falta de metabolización de la situación política vivida en Euskal Herria, emplear la fuerza (incluso si es a nivel simbólico o ritual) se ha convertido en tabú, y esto se está utilizando para limitar las acciones de las mujeres" (2017: 109). 


\section{METODOLOGÍA y PROCESO METODOLÓGICO}

La metodología es un área controvertida en el mundo académico, y no ha pasado desapercibido entre las académicas feministas. De hecho, hay todo un cuerpo literario discutiendo la existencia de la denominada 'metodología feminista' y de lo que la caracteriza (Harding, 1998; Huisman, 2008). No obstante, no me detendré en estas discusiones a pesar de su interés, y sin dar más rodeos me posicionaré desde una metodología feminista y crítica que tiene como objetivo reflexionar y exponer como parte de la investigación los dilemas éticos, privilegios, posicionalidad, dinámicas de poder e intersubjetividades presentes durante toda la investigación y las estrategias escogidas para hacer frente a todo esto. En otras palabras, he tratado de tener en mente a lo largo de todo el proceso lo siguiente:

"who can be a 'knower', what can be known, what constitutes and validates knowledge, and what the relationship is or should be between knowing and being (that is, between epistemology and ontology) ${ }^{7 "}$ (Stanley y Wise 1990, 26 en Motapanyane, 2010: 96).

La epistemología feminista critica la perspectiva misógina y androcentrista de las epistemologías tradicionales, las cuales se presentan como objetivas y universales (Harding, 1998; Ferrandiz, 2011; Gregorio, 2006). En otras palabras, la metodología feminista intenta exponer la denominada objetividad positivista la cual esconde subjetividad patriarcal. Lo que plantea la epistemología feminista es que "knowledge and truth are partial, situated, subjective, power imbued and relational. (...) Experience is shaped by one's particular context- specific circumstances, conditions, values and relations of power" (Hesse- Biber, 2007: 9).

De esta manera, la metodología feminista defiende que todo proceso de investigación está influenciado por los valores de la/ del investigador/a (Hesse- Biber, 2007). Esto implica, entonces, desmantelar y retar los postulados de las epistemologías tradicionales positivistas las cuales sitúan a la/el investigador/a como observante y analista ajen/a a la realidad social. De hecho, la metodología feminista propone todo lo contrario, y propone el "conocimiento situado" (Gregorio Gil, 2006: 27) como estrategia para desenmascarar las múltiples dinámicas de poder que se producen en los procesos de investigación.

El reconocimiento de los diferentes ejes que construyen y subjetivan el conocimiento situado que construimos en las investigaciones, por lo tanto, requieren de la reflexividad

\footnotetext{
7 "quién puede ser una "conocedora", qué puede ser conocido, qué constituye y valida el conocimiento, y qué relación hay o debería de haber entre sber y ser (es decir, entre epistemología y ontología" (Stanley y Wise 1990, 26 en Motapanyane, 2010: 96).

8 "El conocimiento y la verdad son parciales, situados, subjetivos, impregnados de poder y relacionales" (Hesse- Biber, 2007: 9).
} 
y posicionalidad como ejercicios constantes e imprescindibles que debemos practicar durante todo el proceso de investigación, y que es lo que caracterizará una metodología feminista (Alcázar, 2010; Gregorio Gil, 2006):

"La reflexividad planteada desde el feminismo considera al antropólogo/a en la dimensión política imbricada en las interacciones sociales en el trabajo de campo y obliga a llevar un proceso de autoconciencia en el que el género toma un lugar central" (Gregorio Gil, 2006: 31).

De este modo, la reflexividad es un mecanismo de responsabilidad y compromiso político y personal de la/el investigador/a hacia su posición durante todo el proceso de investigación.

Esta epistemología y metodología feminista es de la que he partido en mi proyecto, y la cual ha guiado el proceso de investigación desde el planteamiento de las preguntas de investigación hasta la redacción del propio texto. El objetivo de este capítulo es describir precisamente este proceso personal de "comprensión con [mis] perplejidades, descubrimientos, temores" (Gregorio Gil, 2006: 32) y de cómo he navegado a través de todo ello.

\subsection{El Desarrollo del Planteamiento del Proyecto: Un Proceso de Diálogo Crítico e Intersubjetivo}

Comencé mi camino en este proyecto desde el interés y atracción hacia la performatividad y representaciones que hacían uso de la violencia simbólica por parte de ciertos grupos feministas de Euskal Herria. Mi perspectiva y acercamiento al tema de investigación se ha desarrollado, complejizado y enriquecido a lo largo del proceso dialectico y crítico de la investigación. A través de leer textos académicos, cuestionar mis ideas y su origen (¿androcéntrico a veces tal vez?), leer blogs de grupos feministas ${ }^{9}$ y compartir conversaciones con activistas que han participado en la organización de las manifestaciones y compañeras del máster, es como he llegado al planteamiento que en el presente trabajo presento finalmente. No ha sido, de ninguna manera, un proceso lineal y sencillo, pero considero que es todo esto precisamente lo que me ha posibilitado explorar y entender la complejidad, multidimensionalidad e intersubjetividad de la realidad que tengo como objeto.

Siempre me he sentido atraída e interesada en las acciones y discursos directos del activismo feminista, enzarzándome continuamente con amig@s y familiares en debates

\footnotetext{
${ }^{9}$ El blog y Facebook de Medeak fue clave en el giro de perspectiva que tomé en febrero- marzo, cuando aún intentaba delimitar cuál sería mi objeto de estudio y mi acercamietno a él. Especialmente el post “¿Ha cambiado el miedo de bando?", publicado el 14 de diciembre del 2015, accesible en: https://medeak.wordpress.com/2015/12/14/ha-cambiado-el-miedo-debando/
} 
intensos tratando de justificar y argumentar la necesidad de aquello que muchas veces ha sido tachado de feminazi o inapropiado por ser interpretado como 'demasiado agresivo o violento'. Por ejemplo, pancartas lanzando mensajes tales como "jaia gunean, matxirulorik ez ${ }^{10 "}$ serían la raíz de acalorados debates en noches de fiesta con mi cuadrilla. Otro caso entre muchos otros, ocurrió el año pasado, durante la Semana Grande de las fiestas de Bilbo. Atendíamos a un concierto en la zona de choznas y el concierto fue pausado para protestar y recordar que el entorno festivo no es un entorno libre de machismo y agresiones, por lo que junto a un pequeño speech directo y sin remordimientos en el escenario, un grupo de activistas, se colaron entre las personas que estábamos viendo el concierto lanzando panfletos sobre "no a las agresiones machistas", mientras por los altavoces de las choznas se oían reivindicaciones que dejaban claro que cada agresión va a tener respuesta, del índole que sea.

Como en otras ocasiones, esto causa revuelo en mucha gente, pues la exposición de un conflicto estructural y el llamamiento a la atención de los privilegios masculinos, especialmente en un entorno 'festivo', es percibido como un atentado a la comodidad en una posición de privilegio y amnesia política e histórica misógina. Sin embargo, se ataca a estos actos llamando la atención a la forma de lanzar el mensaje, por mostrar ampliamente irritación y no estar dispuestas a tolerar ni una agresión más. Sarah Ahmed (2011) hace referencia a estos actos de llamar la atención a opresiones y privilegios actos de "feminist killjoy", o "feministas aguafiestas". A través de este término la académica feminista considera que las denuncias de diversas opresiones que realizamos en nuestra vida diaria, forman parte de "killing joy as a world making project $^{11 "}$, palabras con las que me he estado sentido constantemente identificada durante todo el proceso de investigación.

A pesar de estos principios políticos, paradójicamente, incicialmente tenía una postura ambigua en torno a las manifestaciones que en algunas ciudades de Euskal Herria se han llevado a cabo en los últimos años y que han hecho uso de violencia simbólica y lo que en este trabajo estoy denominando violencia performativa. Al comenzar a articular el objeto y objetivos del proyecto, me preguntaba si las formas de representación combativa y que evocan ideas de violencia podían considerarse como estrategias masculinistas que los grupos habían optado con el objetivo de ser efectivas en un contexto y espacio socio político nacionalista en el que la masculinidad o lo masculino se privilegian (Spike Peterson, 1999). Es decir, me preguntaba y planteaba si estas

\footnotetext{
10 "En entorno de fiestas, no a los machirulos".

11 "Ser aguafiestas como (forma de) Proyecto de Hacer/ construcción de mundo" (Ahmed, 2011).
} 
formas de performatividad del MFV podían considerarse un caso de "to be effective, women are drawn toward masculinist strategies ${ }^{12 "}$ (Spike Peterson, 1999: 51).

De esta manera, me preguntaba a mí misma si a través de esta elección de estética violenta podríamos estar reproduciendo, reforzando y legitimando específicas actitudes y valores de género (masculinizadas), especialmente en el contexto específico de los movimientos sociales que ocurren dentro del MLNV, que resulta particularmente masculinista, debido a la historia nacionalista y la involucración en el movimiento de liberación nacional.

Dicho en otras palabras, me preguntaba si había un "imperativo performativo" el cual los grupos feministas estaban siguiendo con el objetivo de acercarse a un 'ideal' que dicta qué formas de protestar son inteligibles en el contexto socio político del MLNV. Querer acercarse o aspirar a un ideal (el cual está definido por tradiciones masculinistas y androcéntricas), deja en evidencia la existencia de normas que regulan lo que es inteligible. Por lo tanto, me interesaba explorar la naturaleza generizada, concretamente masculinizada, de esas normas regulativas de lo que aparece en el espacio publico del MLNV, teniendo en mente las palabras de Judith Butler (2009):

"When we act, and act politically, it is already within a set of norms that are acting upon us, and in ways that we cannot always know about ${ }^{13 "}$ (2009: xi).

De esta manera, me planteaba si, parafraseando las palabras de Sarah Ahmed (2004): "la norma es regulativa, y está apoyada por un ideal que asocia conducta [política] ${ }^{14}$ con otras formas de conducta" (149). Es decir, si entendemos que las normas de género están directamente relacionadas con esas normas de conducta (política especialmente), hacer uso de violencia performativa que evoca el conflicto armado del MLNV puede contribuir a la validación de una única forma de aparición en el espacio público: aquella producida por ideas generizadas del nacionalismo vasco.

No obstante, este inicial acercamiento a mi objeto de estudio, como he mencionado previamente, sin descartarlo del todo, se desarrolló y complejizó a través de un proceso dialéctico, crítico e intersubjetivo que fue formado por las interpretaciones de las propias activistas que organizaron dichas manifestaciones y las entrevistas que realicé con algunas de ellas. De acuerdo con la epistemología feminista que rompe con la tradición positivista la cual piensa que el mundo social es un realidad que la/el investigadora

\footnotetext{
12 "con el objetivo de ser efectivas, las mujeres son arrastradas hacia estrategias masculinistas" (Spike Peterson, 1999: 51).

13 "cuando actuamos, y actuamos políticamente, lo hacemos dentro de un conjunto de normas que están actuando sobre nosotras, y en formas de las que no siempre somos conscientes o sabedoras" (Butler, 2009: xi).

${ }^{14}$ La cita original en vez de hacer referencia a la conducta política, hace referencia a la conducta sexual. Por lo que la cita original es la siguiente: "la norma es regulativa, y está apoyada por un ideal que asocia conducta sexual con otras formas de conducta" (Ahmed, 2004: 149).
} 
puede de forma objetiva y exterior entender y explicar para así crear explicaciones del mundo social como causa- efecto, considero que mi investigación ha sido un proceso dialógico y crítico entre $\mathrm{mi}$ experiencia, mi subjetividad y las perspectivas e interpretaciones de las activistas con las que he dialogado y me he entrevistado.

Por lo tanto, a través de lo que Carmen Gregorio Gil y Adela Franzé (2006: 87) denomina "disposición al extrañamiento" o ejercicio sistemático al extrañamiento, mi investigación ha sido un ejercicio sistemático y constante de cuestionamiento de los criterios implícitos de normalidad o naturalidad que anidan en toda sociedad o contexto para convertirlos en categorías revisables y objetos de indagación. Es decir, un proceso de incesante disposición a descotidianizar o extrañar lo cercano.

El resultado de cómo he finalizado dirigiendo o enfocando el tema de la violencia performativa, entonces, ha sido un proceso de querer captar el mundo social como espacio de puntos de vista, representaciones múltiples y complejas, a menudo contradictorias a través de las que los agentes sociales se acomodan y reacomodan a los contextos específicos y definen constantemente su situación y sus marcos de acción. En pocas palabras, ha sido el diálogo intersubjetivo lo que ha hecho posible mi proyecto final. Tanto entrevistas de las activistas del MFV en periódicos y revistas online, como sus blogs y sobre todo las entrevistas que yo realicé, son las que me posibilitaron ver más allá de mi planteamiento inicial sobre el uso de violencia performativa. Sin la apertura de perspectiva la cual fue posible gracias al diálogo con las activistas/ sujetas, podría haber caído en un discurso problemático sobre el uso de violencia política por mujeres, como señala West (2005) acerca del análisis de las "black widows" (viudas negras) en el conflicto checheno.

\subsection{Las Entrevistas: Representación, Autoría y Temores}

Querer mostrar la complejidad y diversidad de subjetividades, sin embargo, no es un proceso sencillo y ajeno a dilemas éticos y más aún cuando tu trabajo involucra la participación de otras personas. La relación con las activistas ha sido un elemento fundamental en mi proceso de intentar entender mejor la violencia performativa de las manifestaciones del MFV. Sin embargo, esto no estuvo ausente de muchas ansiedades y miedos respecto a mi posicionalidad, autoría y representaciones.

Desde el comienzo del trabajo, cuestionaba y me incomodaba mi autoría en cuanto a mi posicionalidad con respecto al tema que quería abordar y a las personas a las que contacté. Es decir, "me cuestionaba mi legitimidad para hacer esta exploración" (Ghasarian, 2008: 29-30). A pesar de haber estado siempre interesada en diferentes actividades organizadas por diversos grupos feministas, mi involucración se ha limitado a ser participante. Es decir, no he sido activista colaborando en los trabajos de 
organización, lo que me hacía sentir no legitimada para escribir sobre ello al sentir que soy una "outsider", o desde luego, no una "insider" de los grupos en los que me iba a enfocar. No obstante, al mismo tiempo, comparto con Nancy A. Naples (1996) que las posiciones "insider"/ "outsier" no son fijas y estables, sino que son localizaciones sociales relacionales y cambiantes, estando continuamente afectadas por las relaciones de género, raza y clase. Es decir, mi interés por el tema surge por cierta forma de involucración e interés político y feminista que siempre me ha hecho estar en contacto de alguna forma con el movimiento feminista vasco. Por lo tanto, mi posicionalidad es más compleja que poder definirla a través de una categoría fija como simple y exclusivamente una outsider.

Aun así, me preocupaba mi posicionalidad por dos razones principales. Primeramente, por cómo mi posicionalidad afecta mi "interpretative authority"-autoridad interpretativa(Borland, 1991: 64) y la validez o autoría o legitimidad como investigadora (Ghasarian, 2008). Es decir, era consciente que a la hora de redactar, analizar y representar a las sujetas o participantes, mi posicionalidad es particularmente delicada como no- insider, y no sólo esto, también me preocupaba cómo equilibrar mi poder al estar a cargo de la redacción, y en consecuencia, de las representaciones que surgen de mis interpretaciones y análisis. Tal y como indica Katherine Borland (1991: 65):

"How might we represent our work in a way that grants the speaking woman interpretative respect without relinquishing our responsibility to provide our own interpretation of her experience?".

Esta reflexión evidencia la responsabilidad como investigadora del "power of authorship"- poder de autoridad- (Roseneil, 1993: 204), esto es, mi posición de mayor poder al estar al cargo de la escritura. $Y$ en mi caso en concreto, consideraba que esta cuestión ética que está presente en toda investigación, se acentuaba debido a "mi no pertenecer" a ningún grupo feminista que organiza las manifestaciones que estoy estudiando. Dicho de forma muy breve, mi preocupación era básicamente lo que Marjorie DeVault (1996:38 en Huisman, 2008: 373) señala así: "concerns about exploitation and misrepresentation come into play whenever data come from human informants". De alguna forma, mis temores hacia mi posición y las representaciones que construya, se reducen a mi responsabilidad ética y política hacia otras personas en mi relato.

Además de mi legitimidad y responsabilidad, también me preocupaba cómo las activistas con las que contacté me verían, precisamente por lo mencionado y que se sintieran ofendidas por cómo planteo las manifestaciones en las que ellas han invertido cuidadosamente trabajo, tiempo, energía y pasión. La verdad es que todas las personas con las que estuve en contacto fueron accesibles, cercanas, amables, entusiastas, inspiradoras y más que colaboradoras. No sólo las personas que entrevisté 
directamente y las que presento en el siguiente subapartado, sino todas las activistas y académicas que contacté a lo largo del proceso, en especial, Jone Martínez Palacios y Jule Goikoetxea. Todas ellas y su implicación conmigo no pudieron hacer mi experiencia más enriquecedora y fácil, y les estoy verdaderamente agradecida.

Por último, otro factor que alimentaba mis ansiedades era mi interés en indagar las representaciones del MFV que hacen uso de violencia performativa y cómo eso se negocia con la evocación a la lucha armada del MLNV en el actual momento político de resolución de conflicto.

Para hacer frente a estas preocupaciones, mis estrategias fueron las siguientes. Por una parte, traté de equilibrar las dimensiones o perspectivas Emic y Etic (Dietz, 2010). Es decir, intenté incorporar la interpretación de las actoras, las sujetas, de las personas con las que estudié (perspectiva Emic), junto con mis perspectivas y análisis (perspectiva Etic). Sin embargo, soy consciente que en mi caso la dimensión Emic no es estrictamente de las sujetas, ya que no es un texto colectivo, por lo que lo que presento en este trabajo pasa por mí, es decir, es todo el tiempo Etic.

Por otra parte, intenté plantear las entrevistas de manera que fueran lo menos similar a 'técnicas de extracción' posible, y que se acercaran más a un diálogo que me permitiera entender la complejidad y multi- dimensión de lo que quería explorar en el trabajo. Tanto el intento de equilibrar las dimensiones emic y etic, como plantear la entrevista como un dialogo intersubjetivo, son un intento de evidenciar el potencial peligro de reproducir ideas de investigadora/ conocedora/ agente versus objeto/ no- conocedor/ pasivo. Es decir, un intento de poner sobre la mesa "las relaciones de poder entre investigador e informantes" (Guber, 2001; 122). Es decir, es un intento de reconocimiento de dinámicas de poder que se reproducen cuando investigamos, lo cual se ignora en epistemologías y metodologías no feministas y críticas.

Para ello, consideraba importante que las activistas que entrevisté desde el primer momento en que me ponía en contacto con ellas, supieran claramente en qué consistía mi trabajo. Para ello, si después de la explicación dada al presentarme y decirles que estaba interesada en poder hablar con ellas, si estaban de acuerdo en hacer la entrevista, entonces, les enviaba una forma de consentimiento. Esta forma de consentimiento describe el proyecto, básicamente. El objetivo de este documento, no era formal, sino que mi intención era la siguiente. Por una parte, lo consideraba un mecanismo de presentarles más detalladamente en lo que consistía mi acercamiento al tema, de manera que podían decidir tranquilamente si estaban de acuerdo con llevar a cabo a entrevista o no. Por otro lado, también lo consideraba una pequeña plataforma desde la que podíamos debatir diferencias de opinión o enfoques, si es que los había antes de que nos embarcáramos en la discusión. 
Desde el momento de contacto, siempre intenté dejar claro que uno de los aspectos más importantes de las entrevistas/ conversaciones era poder crear un espacio en el que me pudieran debatir, argumentar y contra- argumentar ideas. Disfruté la involucración de todas ellas y gracias a ello, creamos un diálogo en el que pude plantear dudas que me surgían a lo largo de mi investigación. Debido al fluido envolvimiento en las entrevistas, ellas y sus planteamientos fueron imprescindibles en el proceso crítico de la investigación.

\subsection{Técnicas de Investigación: entrevista dialógica, análisis discursivo y observación participante}

Combinaré el diálogo entre análisis discursivo de tres textos, entrevistas semiestructuradas, interpretaciones de imágenes y lemas y observación participante. Por medio de la entrevista semi- estructurada y análisis discursivo de los textos escogidos, quiero explorar las motivaciones políticas de emplear violencia performativa, cómo interpretan las opiniones que problematizan tal estética y su interpretación del uso de símbolos como el pasamontañas, y en particular en relación al contexto socio- político del MLNV.

Los textos escogidos para realizar el análisis discursivo son tres. El principal criterio para la elección fue la posición promotora, y discurso desarrollado en torno al uso de la violencia performativa dentro del MFV. Como he dicho, a pesar de que este planteamiento es compartido por numerosos grupos feministas vascos, voy a señalar tres colectivos en particular, Farrukas, Medeak y OihuK, dado a que han sido cruciales en la elaboración de un discurso político y han participado muy directamente en la organización de manifestaciones en las que se hace uso de esa violencia performativa de la que vengo hablando.

Concretamente, trabajaré con el artículo ¡Pasa la capucha, hermana! del colectivo propulsor de las manifestaciones nocturnas FARRUKAS (Feministas Autónomas Revolucionarias y Ruidosas Unidas Kontra las Agresiones Sexistas) de Iruña; una entrada del blog de Medeak del 2015; y un capitulo del libro "Transfeminismos" (Solá y Urko, 2014) escrito por el grupo transfeminista Medeak. Además, he realizado cuatro entrevistas semi- estructuradas. Dos de ellas con participantes de los grupos referentes mencionados: Iraultza de Medeak y con Betize del colectivo Oihu K de Bilbo. Junto con ellas, entrevisté a Maialen, activista de la Asamblea de Mujeres de Araba y Hodei, activista del Euskal Herriko Bilgune Feminista. De esta manera, tengo como objetivo exponer la ideología y motivación política que hace posible una lectura profunda de las representaciones, implicaciones políticas y potencial político del empleo de violencia performativa en el contexto vasco. 
El manifiesto o artículo titulado “iPasa la capucha, hermana!" de FARRUCAS (2016) y publicado en diversas revistas online, entre ellas, en Pikara Magazine (12/05/2016). Como he explicado en el capítulo primero, fue el grupo feminista Farrukas de Iruña el que propuso la primera manifestación nocturna pre- Sanfermines en $2014^{15}$ con la estética y performatividad que se agencia del miedo a través de símbolos como el pasamontañas y eslóganes combativos y desafiantes.

En su blog se presentan como "FARRUKAS: Feministas Autónomas Revolucionarias y Ruidosas Unidas Kontra las Agresiones Sexistas". Se identifican como "un grupo intergeneracional, heterogéneo y autónomo". Las brutales agresiones machistas del 2013 intensificaron el movimiento feminista en Iruña, en concreto para hacer frente al contexto festivo. Y fue en el año 2014 tomando como punto de inflexión las agresiones que ocurrieron en especial en las fiestas del barrio de la Txantrea de Iruña, que no fueron las únicas, pero que tuvieron un gran eco social y comunicativo, que empezó a desarrollar el actual grupo de Farrukas. Así, fue la manifestación nocturna preSanfermines del 2014 la primera actividad de este colectivo feminista, y esto marca lo que en su blog el grupo establece como sus objetivos. En este texto escogido justifican el por qué de esta estética y en especial del pasamontañas.

Los dos textos restantes, son ambos del grupo transfeminista Medeak. Desde que formaron el grupo en el 2000, han sido promotoras y son referentes del transfeminismo en Euskal Herria, el cual llegó aquí con mas retraso que a Estados Unidos y Europa, incluyendo Madrid o Barcelona (Epelde et al., 2015). La calle y los cuerpos son los ejes de su política y acción feminista, declinándose así por las performances como forma de texto político. Uno de estos textos se titula "Violencia y Transfeminismo. Una Mirada Situada" y es un capitulo del libro "Transfeminismos. Epistems, fricciones y flujos" de Solá y Urko (2014) en el que exponen, por una parte su compresión situada del transfeminismo, y su lectura de la violencia desde este postulado político y la propuesta de la reapropiación de técnicas performativas del miedo como forma de respuesta o acción política feminista. Por último, la entrada del 14 de diciembre en el blog de Medeak titulada "Ha cambiado el miedo de bando?", en el que reflexionan sobre el empleo de técnicas de violencia simbólica en manifestaciones de Euskal Herria a lo largo de 2014 y 2015 y las reacciones negativas ante esto.

Será a través de análisis discursivo, es decir, análisis de las fuentes textuales, que abriré la conversación con estos textos. Debo puntualizar que comprenderé el análisis discursivo como una forma de "<<situar $>$ los análisis del discurso en sus contextos

\footnotetext{
${ }^{15}$ En el siguiente link se encuentra un video con imágenes de aquella manifestación en contra de las agresiones machistas en Sanfermines propuesta por el grupo feminsita Farrukas: https://www.youtube.com/watch?v=_wedFpTS5XU
} 
materiales, y observar así de manera más sistematizada sus relaciones con otros elementos de análisis" (Azpiazu Carballo, 2014: 121). Es decir, mi foco se dirigirá principalmente a las premisas políticas desde donde estos textos surgen, así como el entorno en el que se dan lugar. Junto con esto, también daré importancia al marco teórico y contextual que he construido en los siguientes capítulos, los que se combinarán en el análisis.

Trenzaré y pondré en diálogo el análisis de los textos mencionados con las entrevistas realizadas con cuatro activistas feministas del MFV, así como con las interpretaciones de imágenes y lemas. En consecuencia de los principios metodológicos mencionados a lo largo del capitulo, traté de plantear las entrevistas como dialógicas, es decir, como un medio para comenzar un debate y conversación en torno a los temas que quería indagar. Por supuesto, esto no erradica mi posición de poder en este proceso, ya que la entrevista surge de mi propuesta, y en busca de responder aquellos ítems que establecí como mis objetivos de estudio (Ghasarian, 2008). Sin embargo, intenté potenciar ser interpelada durante dichas entrevistas por las participantes.

A la hora de acercarme a posibles participantes, me puse en contacto con activistas que en las diferentes manifestaciones que tengo como objeto de estudio han participado desde diferentes posiciones. Prioricé la involucración en algún grado de las activistas ya que consideraba y enfatizaba desde el comienzo la importancia de los motivos políticos que promueven los actos políticos que hacen uso de violencia simbólica, pues considero esto un requisito para poder indagar las representaciones del MFV en las acciones políticas organizadas en contra de agresiones machistas. Fue la técnica de la 'bola de nieve' a través de la que conocí a las activistas, a través de amigas al principio, y las propias participantes después.

La primera activista con la que contacté fue Maialen ${ }^{16}$, activista del MFV, actualmente participante de la Asamblea de Mujeres de Álava, y que colaboró en la organización de la manifestación nacional "11 eraso, 12 erantzun". Tras las hostiles reacciones de ciertos sectores de la sociedad vasca hacia las manifestaciones nocturnas pre- fiestas e incluso intentos de criminalización y desprestigio hacia el movimiento feminista ${ }^{17}$, el 9 de abril del 2015 el Movimiento Feminista Vasco organizó la manifestación nacional "11 eraso, 12 erantzun, Feministok Prest! Vuestras agresiones tendrán respuesta". Entre las actividades programadas para este día de reivindicación, una de las formas de

\footnotetext{
${ }^{16}$ Los nombres son inventados con el objetivo de mantener el anonimato de las activistas con las que estuve en contacto.

${ }^{17}$ Como el caso de la denuncia a dos activistas feministas que participaron en la protesta del paseíllo de neskas y blusas en la semanala grande deGasteiz en agsot de 2015.
} 
representación fue la estética de la apropiación de técnicas performativas de la violencia.

Como he remarcado en el capitulo primero, identifico la incorporación de la simbología del miedo, tal y como la del pasamontañas, por el Euskal Herriko Bilgune Feminista. Por ello, estimé relevante ponerme en contacto con una activista del BF. Y es así como tuve la opción de hablar con Hodei, activista que lleva militando en el grupo Bilgune Feminista 12 años, concretamente en el de Algorta y que también participa en una de las comisiones de fiestas (mixta) de Getxo. Anteriormente también fue activista del movimiento okupa del Gaztetxe de Algorta.

En tercer lugar, debido a su involucración en la manifestación de encapuchadas en "11 eraso, 12 erntzun" en 2015 y la participación en las manifestaciones nocturnas de Bilbo celebradas en 2015, 2016 y 2017, me puse en contacto con una activista de el colectivo Oihuka, Betize, que simultáneamente es activista en la Autodefentsa Feministarako Asanblea (AFA) de Bilbo.

Por último, tuve la oportunidad de entrevistar a Iraultza del grupo Medeak, el cual considero muy relevante en relación a mi objeto de estudio por las razones previamente expuestas.

Cada una de las entrevistas llevadas a cabo es profunda y reflexiva, y todas ellas me supusieron interrogarme ideas, a la vez que aportaron nociones, visiones e perspectivas muy interesantes. Debido a la extensión del trabajo y considerando la relevancia de las entrevistas llevadas a cabo, consideré apropiado centrarme en estas cuatro entrevistas y dedicar más profundidad a cada una, en vez de buscar más entrevistas en cantidad y no profundizar tanto.

\subsection{Saliendo del anonimato, exposición de mi posición en la investigación}

El desarrollo de mi proceso de investigación, finalmente, constata mi total participación en el mundo social y político que tengo como objeto de estudio, haciendo así imposible sostener que como investigadora, me puedo posicionar como observadora externa del mundo que exploro (Ghasarian, 2008). Por ello, he intentado hacer frente al proyecto teniendo en mente mis responsabilidades éticas y políticas hacia la realidad que analizo y las representaciones que hago.

Finalmente, el objetivo de este ejercicio de exponer cuál ha sido el desarrollo metodológico que me llevó desde un inicial planteamiento de proyecto, a la redacción final de mi TFM, es intentar explicar mi posicionalidad de manera que las personas que me lean, sepan desde dónde vivo, percibo e interpreto; lo cual entiendo que es lo que propone la metodología feminista: hacer transparente la subjetividad desde la que parto, 
exploro y narro. Es decir, evitar una posición de anonimato como forma de narradora omnipresente, pues, sin una exposición critica de nosotras mismas, no complejizaríamos las realidades que tratamos de entender. En otras palabras, es un intento de ser conscientes

"de la ficcionalidad y textualidad del proceso de investigación y de que cualquier acto de investigación implica una serie de opciones de autoría y estrategias (...) y que por lo tanto la investigación es en sí una construcción discursiva constitutiva de 'construir el mundo'" (Baxter, 2004: 6, en Azpiazu Carballo: 120). Es este desarrollo de mis ideas el que, finalmente, me llevó a la articulación de los objetivos de investigación, que presento en el próximo apartado.

\subsection{Objetivos de la Investigación}

Las protestas y acciones que hacen uso de capuchas y fuego llevadas a cabo por el MFV para responder a las violencias machistas no han pasado desapercibidas. De hecho, han creado molestia, llamado la atención y recibido críticas por parte de diversos sectores de la sociedad vasca: desde anti- feministas hasta feministas.

La controversia en torno a la performance y estética llevada a cabo por el MFV muestra tensiones que tienen como origen representaciones de género que resultan "incómodas" y tensión entre feminismo y nacionalismo. Halberstam observa una reacción similar hacia las masculinidades femeninas, y señala que "la masculinidad femenina es particularmente interesante como objeto de investigación porque ha sido denigrado/ vilipendiado igualmente tanto por programas heterosexistas como feministas" (1998: 9). Es por reacciones similares ante las performances de las manifestaciones nocturnas por lo que considero relevante examinar la performatividad de estas manifestaciones organizadas bajo el lema "El Miedo Va a Cambiar de Bando".

Para poner en conversación y abordar las técnicas performativas de las protestas del MFV en contra de agresiones machistas y entender la polémica que le rodea, considero interesante aplicar el concepto que Butler denomina "performative contradiction" (2007: 63). Sugiero que las protestas bajo el lema "El Miedo Va a Cambiar de Bando" Ilevadas a cabo por el MFV puede considerarse una contradicción performativa, ya que mujeres están haciendo uso de técnicas performativas de la violencia, agresividad y miedo, que a través de leyes simbólicas, se nos está 'prohibido' a las mujeres. Y además, esto se hace a través del ocupamiento del espacio público, es decir, ocurren DÓNDE no nos corresponde (espacio público: calles, plazas), y algunas de estas CUÁNDO se nos es 
prohibido: a la noche ${ }^{18}$.

Originalmente, Butler y Spivak (2007) utilizan este término en el ensayo "Who Sings the Nation-State" para hacer referencia a los inmigrantes hispanos que salieron a las calles de la ciudad de Los Ángeles para reclamar sus derechos civiles en los Estados Unidos. Para ello cantaron el himno nacional estadounidense (originalmente en inglés) en español. Estas autoras denominan el hecho de cantar en la calle, tomando espacio público para reclamar sus derechos, de esta manera, ejerciendo aquellos derechos civiles que les son negados, como contradicción performativa, ya que están ejerciendo la libertad de asamblea dónde y cuándo lo tienen explícitamente prohibido por ley. Dicho de otra manera, reclamar su legalidad como ciudadanos es precisamente lo que es ilegal para ellos.

No ignoro el hecho de que comparar a las trabajadora indocumentadas de California y las mujeres que participan y protestan en el MFV habitan contradicciones performativas diferentes. Hay claramente asimetría entre las diferentes contradicciones performativas, aunque sugiero que mi objeto de estudio también constituye una variación de contradicción performativa, pero en este caso la contradicción básica, y que ampliaré y complejizaré en los capítulos cinco y seis, surge entre la performance y discurso de las participantes de las manifestaciones y las normas de género que rompen las participantes de las protestas.

Una vez introducido de forma amplia el acercamiento que tendré al objeto de estudio, propongo el siguiente objetivo principal de investigación:

- "Indagar las representaciones y performance del MFV que se agencian de violencia performativa o técnicas performativas de la violencia así como su potencial político en las acciones organizadas contra las agresiones machistas".

Me gustaría indagar de qué formas las performances y representaciones de las manifestaciones constituyen formas de violencia performativa y qué significa la agenciación de las técnicas de la violencia y el miedo y explorar qué potencial político tiene esta propuesta.

Más concretamente, me gustaría "explorar cómo el sistema de género subyace en el debate en torno al uso de técnicas performativas de la violencia y agenciación del miedo como estrategia política feminista y la forma en la que este sistema produce una contradicción performativa". Dicho de otra manera, quiero explorar

\footnotetext{
${ }^{18}$ A través de esto, no insinuo que la ocupaicion de la calle y la noche sean reivindicaciones exclusivas del MFV, pero enfatizo que éste es uno de los motores políticos de estas protestas que denuncian las agresiones machistas en los ambientes festivos.
} 
cómo el orden de género crea la idea de contradicción performativa. Propongo esta pregunta para así poder dialogar sobre por qué la estética de estas manifestaciones puede ser considerada una contradicción performativa y por qué y de qué maneras esta contradicción causa incomodidad.

Otra línea de criticismo es aquella que reprocha al MFV por apropiar simbolismo, específicamente las capuchas y fuego, que se relaciona al movimiento independentista de Euskal Herria. En esta línea me gustaría "examinar cómo nos informa esta crítica sobre las políticas de género del MLNV y la relación del MLNV con el feminismo". A través de esta pregunta considero que podemos debatir de dónde vienen las incomodidades por el empleo de símbolos relacionados tradicionalmente a la lucha armada del MLNV. De esta manera, me gustaría debatir cómo desafían y/o reproducen o asimilan los grupos feministas tradiciones masculinistas en un contexto político y cultural históricamente masculinista.

En definitiva, a través de estas preguntas de investigación me gustaría hacer un análisis en profundidad de las técnicas performativas llevadas a cabo por las manifestaciones de "El Miedo Va a Cambiar de Bando" y poder reflexionar cómo el MFV negocia con las distintas normas que rigen el espacio público- político cultural particular del MLNV, introduciendo la perspectiva de género.

Me gustaría poner en conversación los distintos conjuntos de normas que intersectan y operan dentro de la cultura política donde estas manifestaciones se dan lugar, y cómo las conductas políticas, el género y el discurso dominante actual sobre el ciclo político de paz interactúan con la estrategia política de la violencia performativa del MFV. De esta manera considero que podemos tratar de discutir debates sobre asimilacionismo y/o subversión a través de exponer que "una no se da cuenta de que esto [las distintas normas regulativas] cuando una ha sido dada forma por ese mundo, e incluso cuando una ha adquirido esa forma. Las normas no sólo tienen formas de desaparecer de la vista, sino que incluso pueden ser aquello que no sentimos conscientemente" (Ahmed, 2004: 148). 


\section{Contexto. LA CODIFICACION DEL ESPACIO PUBLICO- POLITICO DEL MLNV A TRAVÉS DEL EUSKO GUDARIA}

Como he explicado en el capítulo anterior, la relativamente nueva forma de movilización y acción directa del MFV ha vivido un aumento de ataques, tal y como criminalización, en contra del movimiento. Parte de la problematización surgida en torno a estas manifestaciones que se agencian de violencia performativa y promueven la autodefensa feminista en contra de agresiones machistas, ha sido porque la estética elegida recuerda o evoca a la estética del conflicto armado. Considero indispensable dedicar este capítulo a cómo la simbología y actos performativos del MLNV está generizado en su relación con la "cultura del nacionalismo vasco". Además enfatizaré que esta construcción local y nacional de conceptos de feminidad y masculinidad están intensificados, se hacen más monocromáticas y se naturalizan más enfáticamente debido al conflicto armado.

De esta manera, trataré de contextualizar brevemente los actos performativos de la política vasca para poder entender el contexto socio- político y cultural que constituye tanto el contexto social y organizativo y político donde esos actos performativos (protestas principalmente) surgen.

Debido a la elección del MFV por esa estética que recuerda a la lucha armada, centraré la contextualización en la simbología nacionalista del MLNV. Concretamente, por la relevancia de las estructuras y normas culturales, sociales y políticas que se entretejen con o se forman sobre políticas de género, en este capítulo intentaré justificar cómo los binarismos reproducen y mantienen en el centro de la esfera política el sujeto político masculinizado y androcéntrico, concretamente, el modelo cultural de "el gudari", lo cual sucede continua y decididamente. Como desarrollaré más adelante, a través de la circulación, repetición y reproducción de ciertos cuerpos (los gudaris) en el espacio socio- político y físico a través de los rituales políticos, tal y como funerales, la esfera socio política del imaginario colectivo se moldea. $\mathrm{Y}$ este imaginario conlleva una performatividad concreta efectuada por unos cuerpos generizados, masculinizados (Ahmed, 2004 y Aretxaga, 1988).

Finalmente, considero que este encuadre inicial es importante porque parto del postulado de que ningún acto performativo es fortuito, ya que emerge de contextos históricos y culturales específicos, especialmente cuando nos referimos a actos performativos políticos, pues estos surgen y se desarrollan dentro de un conjunto de normas, las cuales pueden pasar desapercibidas o inconscientemente (Ahmed, 2004; 
Butler, 2009) ${ }^{19}$. Simultáneamente, sugiero que las interpretaciones y debates que han surgido a raíz de la estética llevada a cabo en las manifestaciones descritas del MFV están influenciadas por estos idearios colectivos androcéntricos y patriarcales. Por lo tanto, entender y desmantelar los mecanismos que reproducen y mantienen la masculinización del MLNV en cuanto a los actos performativos y simbolismo es interesante para poder hacer un análisis más rico. Específicamente, me detendré en la generización del sujeto político ideal, representado a través del modelo cultural del eusko gudari. En la línea de Begoña Aretxaga (2009), sostendré que el marco simbólicoritual del nacionalismo (generizado) han sido clave en las continuas representaciones culturales, que se mantienen en el imaginario social hasta día de hoy.

\subsection{MLNV: nacionalismo, conflicto armado y políticas de género}

La literatura feminista que aborda el nacionalismo y género, ha demostrado y justificado ampliamente que "todos los nacionalismos están generizados" (McClintock, 1993: 63). En palabras de Nagel (2003: 157), "las naciones son recipientes/ vasijas vacías" que se llenan de contenido de género, sexual o raza. El País Vasco no es una excepción, y sugeriré en este subapartado que esta generización está fuertemente ligada a la intersección de las políticas de género del nacionalismo y el militarismo desarrollado durante el conflicto armado.

El País Vasco toma forma de nacionalismo que busca ser reconocido como estado (Nagel, 2003; Zabalo, 1993), lo que puede ser denominado como "State- Seeking" (Spike Peterson, 1999: 35) o "Independence- Seeking" (Nagel, 2003: 148)²0. La lucha por el mantenimiento de la nación y búsqueda de ser un estado frecuentemente coge forma de conflicto armado, como en el caso del grupo Euskadi Ta Askatasuna en la nación vasca. Yuval Davis (1997) hace referencia a los movimientos armados que tienen como objetivo la liberación nacional como "armadas de liberación nacional" (1997: 101). La entrelazada entre nacionalismo, militarismo y las políticas de género, así, serán centrales para las identidades individuales, colectivas y marco simbólico y ritual del nacionalismo vasco radical ya que marcarán el espacio político y militar de la acción nacionalista como espacio masculinizado.

\footnotetext{
${ }^{19}$ Ambas autoras, al teorizar el conjunto de normas en el que operamos, se refieren al marco que regula la construcción del la identidad de género y heteronormatividad. Sin embargo, yo estoy aplicando estos análisis a las normas que regulan los cuerpos y su uso en la esfera política, ya que también son actos performativos, tal y como Butler conceptualiza la identidad de género.

20 "State- Seeking" (Spike Peterson, 1999: 35) se podría traducir como "nación que busca ser reconocido como estado" o "Independence- Seeking" (Nagel, 2003: 148) podría traducirse como "estado que busca indepedencia".
} 
Esta intersección de nacionalismo y militarismo que se basan en desigualdad de género no es exclusiva del caso del nacionalismo vasco, e incluso en el caso vasco, esta generización y simbolismo difiere dependiendo de la corriente nacionalista en la que nos centramos. Por ello, de forma breve concretaré de qué manera se combinan la cultura nacionalista, militarista y masculinista en el MLNV, así impactando en la construcción de género ideales.

Euskadi Ta Askatasuna (ETA), fundado en 1959 durante la dictadura franquista por un grupo de estudiantes universitarios principalmente de clase- media, católicos y de familias nacionalistas vascas (Hamilton, 2007), pertenece a la corriente de izquierdas dentro del nacionalismo vasco, situándose como antagonista ante la corriente conservadora, representada principalmente por el partido político PNV (Partido Nacionalista Vasco).

Pese a la posición de rivalidad entre ambos movimientos nacionalistas, ETA (y el MLNV en general) también heredó las políticas de género de forma similar al resto de movimientos nacionalistas del siglo XX (Hamilton, 2007), principalmente en cuanto a la simbolización de la mujer como reproductora biológica y cultural de la cultura y etnia vasca, situando así el rol de la mujer en el ámbito privado. A pesar de los orígenes cercanos especialmente en cuanto a políticas de género y posicionamiento en torno a la religión, ambas corrientes nacionalistas divergieron entre otros, en cuanto a la ideología política ${ }^{21}$. Durante los años posteriores al comienzo de ETA en 1959, la ideología política del grupo se basó en teorías revolucionarias como las de Frantz Fanon, Ernesto Guevara, Mao Zedong y Lenin (Zabalo y Saratxo, 2015). Tal y como dice Yuval- Davis (1997), muchos movimientos anti- coloniales como el de Fanon, una de las bases ideológicas del ETA, se han caracterizado por su "machoismo" o "estilo macho" (1997: 60), lo que frecuentemente ha conllevado dejar en segundo plano la posición de las mujeres y otros grupos en los colectivos nacionales.

Precisamente esta jerarquización de conflictos u opresiones dentro del discurso y política nacionalista que tiende a priorizar la opresión de la nación sobre las otras múltiples opresiones estructurales, tales como racismo o machismo, ha sido una de las críticas del movimiento feminista activista y académico vasco (Rodriguez Lara y Etxebarrieta Legrand, 2016), el cual desarrollaré más profundamente más adelante.

He aquí la importancia de, como dice Spivak (2014) en el prefacio del documental "Concerning Violence" y en la línea de pensamiento de Yuval- Davis (1997), analizar las estrategias empleadas por los movimientos de liberación nacional radicales, porque si

${ }^{21}$ No pretendo ilustrar aquí las convergenias y divergencias de los dos principales movimientos nacionalistas vascos. Ver más en Leonisio Calvo (2012); Casquete (2007a,b); Egaña (1996); Zabalo (1993); Zabalo and Saratxo, 2015. 
no, los problemas de largo plazo (así como el machismo) no se abordan ya que quedan escondidos debajo de la superficie de la opresión que se está enmarcando como la primordial. $Y$ el resultado de esto es que "gizon militante publiko ezkertiar independentista horiek, askotan, emakumeen independentzia oztopatzen zuten"22 (Rodriguez Lara y Etxebarrieta Legrand, 2016: $41^{23}$ ).

En pocas palabras, sugiero que el nacionalismo vasco radical, el MLNV, constituye un claro ejemplo de cómo "la cultura y la ideología de la masculinidad hegemónica van de la mano de la cultura y la ideología del nacionalismo hegemónico" (Nagel, 1998: 249), y es que en la construcción del mundo moderno la colaboración entre la masculinidad, colonialismo, imperialismo, militarismo y nacionalismo han tenido un peso muy significativo a la hora de dar forma a la estructura y culturas de las naciones del sistema moderno de estados (Nagel, 1998).

\subsection{El Militante, Guerrero y Político, es hombre}

¿Cómo influye la alianza entre el nacionalismo y el militarismo en la generización de la subjetivación o identidades políticas? De acuerdo con lo dicho, todos los nacionalismos están fuertemente generizados, de manera que en general las construcciones de identidades nacionales son empleadas para definir lo que se consideran buenas mujeres y hombres (Yuval- Davis, 1997). No obstante, muchas feministas enfatizan que este proceso de generización es particularmente fuerte cuando el nacionalismo está involucrado en la lucha por la liberación nacional. La necesidad de proteger la nación frente a la(s) otra(s) busca homogeneizar las identidades políticas, y en el caso de las identidades de género, las polariza y monocroniza (Rodriguez Lara y Etxebarrieta Legrand, 2016). No solo eso sino que la lucha armada se entiende como un espacio simbólico en el que se desarrolla la hombría y masculinidad, lo que contribuye a lo recién mencionado sobre la construcción de masculinidades y feminidades monocromáticas en los discursos e imaginarios nacionalistas. En otras palabras, académicas que han trabajado profundamente este tema declaran que la acción militar y la guerra han sido identificados como punto importante de construcción de masculinidades hegemónicas (Agostino, 1998; Barrett, 2001; Connell, 1995 citado en Hale 2012), ya que la milicia o lo militar se consideran instituciones masculinas, no solo porque la mayor parte de su población la forman hombres, sino porque constituye un espacio crucial para la construcción de la masculinidad en la sociedad en general (Connell, 1995).

22 "esos hombres militantes públicos independentistas de izquierdas, a menudo, obstaculizan o impiden la independencia de las mujeres".

${ }^{23}$ Es un libro electrónico y no dice el número de la página. He escrito el numero del documento PDF. 
En el libro coordinado por Zuriñe Rodriguez Lara y Oihana Etxebarrieta Legrand (2016) recogen diferentes ensayos en torno a una crítica feminista sobre el discurso androcéntrico y patriarcal sobre lo que llamamos el 'conflicto vasco'. Las diferentes participantes exponen cómo en contextos de conflicto armado, "feminitate eta maskulinitate hegemonikoak blindatzeko saiakera egiten da"24 (Rodriguez Lara y Etxebarrieta Legrand, 2016: 8).

Como resultado, aquellas identidades que se salen del grupo dominante o privilegiado, no quedan representadas, o se incluyen y simultáneamente excluyen dependiendo el discurso y el interés político ${ }^{25}$ (Yuval- Davis, 1997). L@s ciudadan@s están situadas en dicotomías y binarios (generizados) que dividen lo público de lo privado. Tal y como muchas académicas feministas sugieren, desde las ciencias sociales androcéntricas se ha tendido a asumir que los agentes o sujetos que protagonizan el ámbito público eran hombres que se identifican con la identidad masculina (Nagel, 2003; Spike Peterson, 1999). De esta manera, al hablar de la identidad del sujeto moderno en relación a ciudadanía, no nos referimos a un sujeto neutral en términos de género, sino a un sujeto masculino.

Por consiguiente, la dicotomía basada en la ideología de diferencia de género, entre otras cosas, codifica las actividades que se dan en el espacio público como masculinas y el nosotros como homogéneo, universal y masculino. Actividades tales como el conflicto armado, la lucha y debate político se dan principalmente en el espacio público, por lo tanto, ellos serán los protagonistas hegemónicos (Spike Peterson, 1999; Rodriguez, 2015). Esta teorización de la división de la esfera publica de la privada en el conflicto armado vasco es explicada muy claramente a través de la metáfora del iceberg por Zuriñe Rodriguez (2015) que explica cómo detrás o debajo de la labor llevada a cabo en la esfera pública y visible, hay una labor que se está ignorando y minusvalorando en la esfera privada que queda bajo el agua, por lo tanto en la parte del iceberg que nadie ve. $Y$ esta labor invisible es la que hace posible lo que se hace en el debate y lucha política pública.

En esa esfera pública y visual, de acuerdo con lo dicho anteriormente, son precisamente aquellos que se relacionan con "fuerza, vigor, pasión para la lucha y racionalidad" (Rodriguez, 2015: 22) los sujetos públicos. Y es que, según Enloe (1990: 56), “cuando

\footnotetext{
${ }^{24}$ En contextos de conflicto armado "se intentan blindar masculinidades y feminidades hegemónicas".

${ }^{25}$ Por ejemplo, Yuval- Davis explica cómo las mujeres se incluirán en las narrativas nacionalistas como reproductoras biológicas y culturales, pero estarán excluidas de otras esferas de la ciudadanía. Ver capitulo 4: Citizenship and Difference del libro Gender and Nation (Yuval Davis, 1997).
} 
un movimiento nacionalista se militariza, el privilegio masculino se arraiga en la comunidad" (citado en Nagel, 1998: 257).

Como consecuencia, las experiencias y perspectivas masculinas de las elites se privilegian, influyendo en cómo estructuramos nuestras categorías conceptuales y actividades concretas, entre éstas, las actividades políticas. A través de la militarización de la lucha política la cultura nacionalista ha sido construida para enfatizar temas culturales masculinos, tales como el honor, valentía o deber (Nagel, 1998). Esto no pasó desapercibido para algunas militantes de ETA. Esta manifestación del privilegio masculino y de lo masculinista es muy explícito tanto en los diarios y reflexiones de la militante que fue asesinada por la propia banda en 1986 Dolores González Katarain (Yoyes) (Aretxaga, 1988, 2005) y en la etnografía llevada a cabo por Miren Alcedo (1997) con ex militantes mujeres de ETA. Tanto Yoyes como otras ex militantes coinciden al manifestar que sentían "la necesidad de masculinizarse" (García, 2015: 30). Y más concretamente, Yoyes manifestó antes de su muerte en sus diarios que ella detectaba que en las décadas de los 70-80 de la banda, las personas con ideología más "agresiva, viril e insensible" ${ }^{26}$ se impusieron sobre otras corrientes de la organización.

Esta generización del espacio y militarización o conflicto armado tiene como consecuencia que cuando hablamos de militantes y el preso universal, nuestro imaginario los codifica en masculino. "Todavía a día de hoy hacemos la identificación del 'hombre militante y la mujer cuidadora' " (Rodriguez Lara y Etxebarrieta Legrand, 2016: 31). Yo lo traigo a coalición porque considero que tenemos este legado en debates actuales como el que discutiré en este trabajo más adelante.

De esta manera, lo que Yuval Davis señala al decir que "las mujeres siempre han cumplido roles vitales y específicos en los ejércitos, pero han estado excluidos de la esfera publica militar" (1997: 98) ${ }^{27}$, puede igualmente ser aplicado al caso del nacionalismo vasco. Esto no es fortuito, sino que está directamente relacionado a las construcciones de identidad binarias que contradicen que una mujer pueda ser violenta y agresiva. Es decir, siguen imperantes las construcciones militaristas y esencialista de

${ }^{26}$ Citas tomadas del Documental Yoyes del programa "Documentos TV" de TVE, realizado en 2011 Disponible en: http://www.rtve.es/alacarta/videos/documentostv/documentos-tv-yoyes/1114480/

Este es el documental que se realizó tras su muerte, en él se leen fragmentos de sus diarios personales, donde ella volcó muchas de sus inquietudes tanto durante su militancia como una vez en el exilio.

${ }^{27}$ Esto queda claramente demostrado en los diversos trabajos dedicados a analizar la participación de las muejres en ETA. Para leer más sobre esto ver: Alcedo, 2006; Hamilton, 2007; Rodriguez Lara, 2012. 
las mujeres como paz ${ }^{28}$, y los hombres como violencia (Rodriguez, 2015: 18; YuvalDavis, 1997: 94).

\subsection{Marco simbólico- ritual del MLNV: portador y reproductor de políticas de genero}

He argumentado que el sujeto político se identifica en masculino y siguiendo una construcción esencialista. Pero, ¿cómo se transmite y representa esto en el sistema simbólico- ritual nacionalista del MLNV y qué consecuencias performativas conlleva? Debido al objeto de estudio en el que las representaciones tanto físicas como simbólicas tienen un peso muy importante, considero imprescindible analizar brevemente el impacto del marco simbólico- ritual del MLNV con el objetivo de poder hacer un análisis cultural y político situado de las manifestaciones del MFV y las percepciones y debates que esta produce dentro de la sociedad vasca. Trataré de argumentar cómo la cultura militarista y la figura del "eusko gudaria ${ }^{29 "}$, codificados como el ideal nacionalista y masculino son (re)producidos a través de los símbolos y rituales políticos del MLNV, estableciendo así un punto de aproximación para los sujetos políticos vascos. Aun así, sostengo que 'nacionalista' y 'masculino' no deben de ser tratados como categorías de análisis diferentes y separadas, sino que mi propósito es recalcar que estos elementos están fuertemente relacionados. $Y$ es precisamente esa interdependencia la que garantiza la persistencia de ese ideal, y en efecto, las implicaciones de esta cultura masculinista, tanto a nivel del movimiento nacionalista, como a nivel más amplio en la sociedad vasca.

Como he dicho, por una parte, el gudari es el modelo o figura cultural que encarna la intersección entre nacionalismo, cultura militar y políticas de género que he desarrollado a lo largo de las páginas anteriores. Este modelo cultural, además de constituir una de las prácticas de reproducción cultural, es un mecanismo de generización del espacio

\footnotetext{
${ }^{28}$ Hay numerosos trabajos que desarrollan la construcción esencialista de la cultura y simbolismo nacionalista vasco de la mujer. No tanto en cuanto a la ecuación de la mujer con la paz pero en cuanto a mujer como reproductora biológica y cultural. Desde puntos de vista más antropológicos, ver Teresa del Valle (1985) y Mari Luz Esteban. Desde perspectiva histórica y sobre las mujeres que participaron en la política del PNV durante los años de la República, ver Mertxe Ugalde Solano (1993).

29 Eusko Gudaria significa "guerrero vasco" en euskera. Utilizaré este término o simplemente "gudari". El término "gudari", aunque fue mencionado antes, es en el contexto de la guerra civil española que empezó a usarse. Concretamente, a comienzos de la Guerra Civil, a partir de 1936, empezó a ser empleado para referirse al bando de nacionalistas vascos que luchaban dentro del bando republicano. Más adelante el término y lo que representa fue adoptado tanto por ETA como por EGI, lo que tuvo una gran influencia en las siguientes generaciones (Casquete 2007a, 2007b). Ver Casquete (2007a), Casquete (2007b) y Fernández Soldevilla (2012) para más detalles en el origen e historia del término gudari.
} 
público y político a través del establecimiento del sujeto político ideal. Las identidades culturales y mitos juegan un papel importante en la construcción de la identidades, ya que muy a menudo las identidades se relacionan a los mitos, símbolos y rituales nacionalistas (Yuval- Davis, 1997).

Los modelos culturales y costumbres culturales impregnan y se entrelazan con la política nacionalista (Aretxaga, 2005; Aretxaga, 2009). Las metáforas culturales pueden ser adoptadas por actores y llevan a conductas o actuaciones. Es decir, una metáfora cultural puede influenciar y facilitar ciertas conductas. He aquí la importancia de los símbolos en las representaciones y acciones culturales, pues tienden a tener consecuencias performativas (Fernández, 1972). En la línea de esta idea, al contextualizar la masculinidad hegemónica en el contexto nacionalista hindú, Banerjee (2003) sostiene que en las políticas actuales los partidos políticos y organizaciones nacionalistas están codificadas en términos de tradición bélica, lo cual no queda lejos de mi argumento.

Hay abundante literatura sobre el uso y las funciones del 'héroe mártir' en los nacionalismos (Casquete 2007a, 2007b), y particularmente, sobre el origen y el desarrollo del uso del gudari en la Izquierda Abertzale. En pocas palabras, todos sitúan la construcción social de estos personajes heroicos dentro del marco simbólico- ritual del nacionalismo, en este caso, vasco. En cuanto a su función, diferentes autores coinciden en afirmar que la funcionalidad es principalmente la de construir un modelo político ideal con el que los militantes se puedan identificar, potenciar la movilización, cohesionar la nación y confirmar la identidad colectiva (Casquete 2007a, 2007b; Fernández Soldevilla, 2012). Por lo tanto, de acuerdo con esa función de crear una figura que representa el sujeto político ideal de un contexto dado, ¿qué nos dice que el modelo de héroe mártir ${ }^{30}$ en la esfera del MLNV esté codificado en masculino, y que sea siempre hijo y hermano ${ }^{31}$ ? (Aretxaga, 2009).

Finalmente, ya que "rituales, ceremonias, prácticas, valores y estructuras también son reflejo de concepciones de masculinidad y feminidad aceptadas" (Hale, 2012: 699), a través de un análisis sobre el papel que juega la figura del eusko gudari en los rituales

\footnotetext{
${ }^{30}$ La figura del gudari como héroe mártir se relaciona con la versión secularizada del mártircaído por Dios. Además, esta figura está inscrita dentro del marco simbolico de relaciones familiares, de ahí que se describa como hijo o hermano de amaberria o aberria (la madre tierra vasca, que simboliza la posición simbólica de las mujeres dentro de la retórica nacionalista vasca) Ver más en Aretxaga (2005; 2009) y Casquete (2007b). ${ }^{31}$ Cuando Begoña Aretxaga (2009) hace referencia al héroe mártir en términos de relaciónes familiares, está subrayando la posición de los hombres, y en contraste, la posición de las mujeres en los rituales de los funerales vascos. Es decir, las mujeresmadres- hermanas que simbolizan la continuidad del pasado y el presente y el rol de cuidadoras y retransmisoras de la cultura (Rodriguez y Etxebarrieta, 2016).
} 
políticos del MLNV, podemos apreciar las concepciones de masculinidad y feminidad aprobadas o reconocidas.

Los medios de transmisión de los modelos y figuras nacionalistas son múltiples: redes sociales, rituales sociales y políticos, vida asociativa o a través de la cultura popular, entre otros (Casquete, 2007b). EI MLNV a través de rituales políticos, tales como cantar el himno Eusko Gudariak ${ }^{32}$ tras las actividades políticas como los funerales de los gudaris, incesantemente reproduce el imaginario nacionalista del gudari y los valores masculinistas de "valor, patriotismo, nobleza, humildad, generosidad (...)" (Casquete, 2007b: 131). Es importante enfatizar estos rituales ya que continuamente reproducen normas, pues así contribuyen en el continuo proceso de sedimentación que naturaliza nociones generizadas y esencialistas de género.

En un imaginario nacionalista donde el actor político principal se iguala, aunque sea a través de símbolos e imaginarios, con un hombre, además un hombre vasco guerrero, ¿qué ocurre cuando el MFV coge las calles, en ocasiones de noche, se apropia de símbolos propios del gudari y reivindica así un conflicto que no es "el conflicto vasco"? Considero que estas políticas de genero del MLNV que polarizan y esencializan tanto las identidades de género como el espacio público y político, explica parcialmente al menos, por qué entendemos que la performance del MFV en las manifestaciones nocturnas se pueda interpretar como contradicción performativa.

${ }^{32}$ La canción (e himno) Eusko Gudariak constituye unos de los más emblemáticos símbolos de sistema simbólico de la Izquierda Abertzale, ya que desde la década de los 70 la forma de finalizar los actos políticos es cantando la mencionada canción con el puño izquierdo cerrado y elevado por encima de las cabezas (Casquete, 2007 ${ }^{\text {a }}$. Finalizar los actos políticos y rituales de la Izquierda Abertzale con la melodía de Eusko Gudariak se practica desde el proceso de Burgos, celebrado en diciembre de 1970 (Casquete, 2007). 


\title{
4. VIOLENCIA PERFORMATIVA y TÉCNICAS PERFORMATIVAS DE LA VIOLENCIA
}

\author{
"Activists' bodily performances, capabilities, and \\ vulnerabilities during political protest produce \\ social, cultural, and political effects" (De Lucca \\ 1999; Spike Peterson 2001 en Sutton, 2007: 130).
}

Para la interpretación de las manifestaciones del MFV que tengo como objeto emplearé, como marco teórico, las siguientes autoras. Primeramente, me basaré en la definición de violencia performativa que Ivonne Manzi (2014) y las contribuciones de Rhodes (2001) en su obra The Voice of Violence. Performative Violence as Protest In the Vietnam Era y el término "técnicas performativas de la violencia" propuesto por Medeak (2014) para discutir las representaciones y performatividades del MFV en sus manifestaciones en contra de violencias machistas.

Con el objetivo de incorporar la perspectiva de género y una lectura socio- cultural e histórica de dichas performances, haré uso de los análisis de Judith Butler y Gayatri Spivak (2007) y su concepto de contradicción performativa; y el análisis de Begoña Aretxaga (1995) el cual aporta un profundo análisis que incluye teoría sobre género y nacionalismo, lo que resulta muy pertinente en mi presente trabajo.

La introducción a mi marco teórico va de la mano con una revisión literaria sobre diversos casos de grupos (feministas o no) de violencia performativa.

\subsection{Sobre violencia performativa y técnicas performativas de la violencia}

Me apoyaré principalmente en los conceptos "violencia performativa" (Rhodes, 2001; Manzi, 2014) y técnicas performativas de la violencia (Medeak, 2014: 78) para definir el enfoque a través del cual analizaré y trataré las performances y representaciones llevadas a cabo en las manifestaciones del MFV en contra de agresiones machistas. Emplearé como referencia teórica el ensayo de Ivonne Manzi (2014) sobre "Performative Violence: Conceptual and Strategic Implications ${ }^{33 "}$. No obstante, esta última no está planteada desde una perspectiva de género, es por ello, que me resulta imprescindible abordar el término que propone Medeak (2014), un grupo transfeminista de Donostia que introduce la teoría de la performatividad de Judith Butler en su análisis sobre el empleo de performances como acciones políticas que se basan en la reagenciación de la violencia simbólica.

\footnotetext{
${ }^{33}$ Violencia Performativa: Conceptual and Strategic Implications" (Manzi, 2014).
} 
Comenzaré por el examen de la violencia performativa término por término. En cuanto al término violencia, debo clarificar que en el contexto de las manifestaciones que tengo como objetivo, siempre estoy haciendo referencia a 'símbolos de violencia o violencia simbólica', lo cual defino como "cualquier forma de atuendo o vestimenta o comportamiento que evoca violencia sin necesariamente amenazar o resultar en violencia directa" (Manzi, 2014). Es decir, evoca a aspectos violentos, pero se limita a una sugerencia o insinuación.

Por lo que respecta al término 'performativo' que emplean Rhodes y Medeak tienen matices diferentes. El término empleado por Rhodes y Manzi hace referencia al adjetivo del sustantivo performance o del verbo performar. Considero que incluso podríamos entenderlo como Butler define performar como la realización simultánea del discurso (Butler y Spivak, 2007), especialmente a través de actos o prácticas políticas ${ }^{34}$. Para Mazi (2014), esta performance ${ }^{35}$ implica la existencia de un público, de audiencia. Esta audiencia captará el mensaje de la performance, lo cual podemos considerar que es su objetivo: comunicar algo o traer atención a una cuestión en concreto, en definitiva, transmitir un mensaje.

No obstante, el origen de 'performativo' empleado por Medeak, surgió en unas jornadas organizadas por el grupo en 2009 con el objetivo de repensar las violencias machistas. En una de las charlas, Beatriz Preciado en aquel momento, Paul actualmente, propuso un paralelismo teórico y abstracto entre el ejercicio performativo, teatral de la masculinidad que se lleva a cabo en los talleres DragKing y el papel que juega la masculinidad, y su performatividad, en las violencias machistas (Medeak, 2014).

Por lo tanto, la concepción de 'performativo' de Medeak se basa en la teoría de la performatividad de Butler (1990), la cual sostiene que el género es performativo y que no es el efecto de una esencia interna o identidad original o primaria. Es decir, que el género se forma a través de una repetición continua de género, la cual funciona como forma de definir y mantener ideales de género. Esta idea se presentará particularmente importante para mis reflexiones en los capítulos donde analizaré las performances y representaciones que se agencian de violencia performativa desde una perspectiva de género.

Así, haciendo uso de la combinación que hace Manzi (2014) entre teorizaciones sobre violencia, performance y rituales, a través de 'violencia performativa' haré referencia al uso de violencia simbólica, es decir, performances que evoquen violencia o agresividad

\footnotetext{
${ }^{34}$ Tal y como la protesta en la que ciudadan@s indocumentados de Estados Unidos tomaron las calles en 2006. Ver más en Butler y Spivak (2007).

${ }^{35}$ Las traducciones de performance a castellano podrían ser (actuaciones o representaciones). Sin embargo, he mantenido el término en inglés ya que considero que la traducción al castellano no es totalmente representativa del significado original en inglés.
} 
sin causar daños o violencia directa que ocurren con el objetivo de transmitir un mensaje. Más concretamente, también consideraré que "performative violence can be seen as a mode of communication through which activists seek to effect social transformation by staging symbolic confrontation ${ }^{36 "}$ (Juris, 2005, 415, citado en Manzi, 2014).

En la línea de la última cita, considero relevante enfatizar que la importancia y las implicaciones de entender los símbolos de violencia como performativos es que se vuelven evidentes sus objetivos comunicativos (Manzi, 2014). Es decir, por medio de símbolos de violencia, como el uso de pasamontañas del MFV, se abren líneas de comunicación entre grupos. De esta manera, y de acuerdo con Rhodes (2001: 4) podemos entender la violencia performativa como "a method of public protest whereby participants created the conditions in which their violent actions became a political text ${ }^{37 "}$. Rhodes (2001) expone en su obra The Voice of Violence. Performative Violence as Protest In the Vietnam Era casos históricos de formas de protesta que hacen uso de violencia política o vandalismo. No obstante, he de clarificar aquí que entre estos casos había algunas formas de vandalismo que difieren de lo que yo he delimitado como violencia, ya que en ocasiones estas protestas provocaron daños físicos, a diferencia de las protestas y performances de mi objeto de estudio. Aun así, he decidido abordar su trabajo ya que a lo largo de su obra, hay casos que se ajustan a lo que yo he definido como violencia simbólica. A través de una interpretación crítica, el autor sugiere que las formas de acción directa que examina están deliberadamente articuladas y cuidadosamente construidas como "a coherent attempt to open lines of communication with white society ${ }^{38 "}$ (Rhodes, 2001: 187).

L@s anteriores autor@s señalan que para poder hacer un análisis que no caiga en un rechazo automático de cualquier evocación a la violencia, es imprescindible prestar atención a las "implicaciones estratégicas o motivaciones" (Manzi, 2014) que guían y articulan el uso de violencia performativa. Tras un análisis exhaustivo los casos históricos que recoge Rhodes (2001) y de la interpretación que éstos tuvieron en la sociedad más amplia, el autor indica que la elección de algun@s activistas estadounidenses de finales de los sesenta por confrontación, resistencia y disrupción

\footnotetext{
36 "La violencia performativa puede considerarse como una forma de comunicación a través de la cual I@s activistas buscan tener efecto en transformaciones sociales a través de la confrontación de símbolos" (Juris, 2005, 415, citado en Manzi, 2014).

37 "Un método de protesta pública a través del cual los participantes crearon las condiciones en las que sus actos violentos se convirtieron en texto político (Rhodes, 2001: 4).

${ }^{38}$ Un intento coherente de abrir líneas de comunicación con la sociedad blanca (Rhodes, 2001: 187).
} 
fue por convicción política de que ese era el único camino para un transformación radical.

Es a colación de esta última idea sobre la necesidad de cambio radicales que me parece interesante ver cómo el uso de la performance es elegida en diferentes momentos históricos, ámbitos y colectivos como estrategia con el objetivo de políticas radicales. $Y$ es que de acuerdo con Butler y Spivak "no puede haber políticas radicales de cambio sin contradicción performativa, ya que si esta contradicción se trabaja y expone, puede llevar a algo nuevo" (2007: 64). El término "contradicción performativa" lo acuñaron para hacer referencia a los inmigrantes hispanos que salieron a las calles de la ciudad de Los Ángeles para reclamar sus derechos civiles en los Estados Unidos. Para ello cantaron el himno nacional estadounidense (originalmente en inglés) en español. Estas autoras denominan el hecho de cantar en la calle, tomando espacio público para reclamar su ciudadanía, de esta manera ejerciendo aquellos derechos civiles que les son negados, como contradicción performativa, ya que están ejerciendo la libertad de asamblea dónde y cuándo lo tienen explícitamente prohibido por ley. Dicho de otra manera, ejercer su ciudadanía a través de una manifestación u ocupación del espacio público con el objetivo de reclamar su legalidad como ciudadan@s es precisamente lo que es ilegal para ellos, y eso constituye una contradicción performativa: llevar a cabo su ciudadanía a través de la performance, de la ejecución. Al mismo tiempo, est@s ciudadan@s decidieron ejercer el derecho que les corresponde a I@s ciudadan@s porque no tienen ese derecho, lo que alimenta la contradicción de la performance.

No obstante, Manzi (2014) hace un apunte interesante en cuanto a las implicaciones que quedan fuera de los objetivos directos que guían a la violencia performativa. Señala que las representaciones de la violencia performativa hacen recordar la historia y temporalidad. En otras palabras, Watson indica que los desfiles organizados en las zonas rurales de Hong Kong y los desfiles de los norirlandeses protestantes a través de las calles católicas de Belfast "'re-enact a history of territorial conflict, keeping the past alive in the present ${ }^{39 "}$ (1996, 150 in Manzi, 2014). Es decir, los actos performativos de violencia (simbólica) crean conexiones con el pasado pues mantienen la historia viva, y esto resulta particularmente doloroso en aquellos contextos en los que se hace un intento constante por "evitar conflicto 40 " (Watson, 1996: 149), como es el caso actual de o denominado proceso de paz en el País Vasco.

Algunos de los efectos que produce un acto político que hace uso de violencia

\footnotetext{
39 "Recrea la historia de conflicto territorial, manteniendo así el pasado vivo en el presente" (Watson, 1996: 150).

40 "Evitar conflicto" (Watson, 1996: 149). Ver más sobre este término que emplea Watson en más profundidad en Watson (1996).
} 
performativa puede que queden fuera de los objetivos inicialmente planteados. Parte de este efecto se debe al contexto histórico y cultural del entorno en el que esto ocurre (Manzi, 2014; Watson, 1996). Sin embargo, considero que en el análisis de los autores mencionados podríamos añadir más factores que afectan a la interpretación del uso de la violencia performativa, entre estos, yo señalo el género. $Y$ es que, "gender norms have everything to do with how and in what way we can appear in public space ${ }^{41 "}$ (Butler, 2009: ii). ¿Cómo impacta el género en las formas de performance elegidas por el MFV para protestar en contra de agresiones machistas? Antes de tratar de responder a esta pregunta, en el siguiente apartado recogeré cómo el género ha impactado en la interpretación de grupos feministas que han optado por alguna forma de violencia performativa.

\subsection{Violencia performativa y género en acción, casos destacables}

Realizaré en este apartado una breve revisión de casos en los que alguna forma de violencia performativa haya sido empleada.

Al intentar encajar la idea de mujeres ejerciendo violencia en la categoría androcentrista de terrorista o guerrero, gran parte de la literatura (no feminista) ha caído en análisis atrapados en los rígidos binarios de masculinidad/ feminidad y público/ privado (West, 2005) y las construcciones generizadas (masculinizadas) de guerra, conflicto y violencia, reforzando así ideas de feminidad hegemónica que coinciden con el discurso dominante patriarcal (Rodriguez Lara y Etxebarrieta Legrand, 2016).

Concebir el constructo 'mujer' irreconciliable con creadora de violencia ha tenido diversas consecuencias. Entre otras, por una parte, se ha victimizado, en lugar de agenciado, a las mujeres que han participado en conflictos armados, justificando su participación a través de razones personales (normalmente noviazgo con el verdadero guerrero político) en vez de por razones políticas. Por otra parte, "a feminine niche is created for women who partake in traditionally masculine activities" (West, 2005: 1). En otras palabras, en palabras de Joseba Zulaika se ha concebido a las militantes como "token terrorists ${ }^{42 "}$ (2009: 64). Es decir, las políticas de genero socio- culturales se han reproducido dentro de los diferentes grupos armados, creando así división sexual y jerarquización entre las tareas que se consideran 'productivas' y 'reproductivas' (Alcedo, 1997; Agra Romero, 2012, West, 2005; Zulaika, 2009).

\footnotetext{
41 "Las normas de género están totalmente relacionadas a cómo y de qué manera podemos aparecer en el espacio público" (Butler, 2009: ii).

42 "Terroristas simbólicas".
} 
Este tratamiento de la participación de militantes en conflictos armados ha sido el caso, entre otros, de las denominadas 'black widows ${ }^{43}$, y las militantes de ETA. En respuesta al tratamiento sexista y patriarcal que las mujeres militantes que participaron en ETA sufrieron, numerosas investigadoras han trabajado en torno a, por una parte, denunciar el sesgo misógino de periodistas y trabajos académicos sobre las militantes armadas (Hamilton, 2007a; Rodriguez Lara, 2012, 2013); por otra parte, investigar desde una perspectiva feminista la participación de las militantes (Alcedo, 1997; Hamilton, 2007b). O sea, se han realizado abundantes trabajos desmantelando las políticas de genero de la banda y del tratamiento y discursos sobre las militantes armadas, y más en general, han expuesto las políticas de género del MLNV, que combina nacionalismo, políticas socialistas- marxistas y políticas de género (Esteban, 2017).

A pesar de las excelentes contribuciones feministas al análisis del uso de la violencia política de las mujeres, no me centraré en estos casos citados ya que tratan de violencia política armada, lo que no constituye mi objeto de estudio, pues como he especificado antes, en este trabajo cuando hablo de violencia performativa, me referiré a violencia simbólica. Es decir, a atuendos y performances que evoquen ideas de violencia, sin que resulte en ninguna clase de daño real o físico. Y es que, además, no hace falta acudir al terreno de violencia política armada para que los cuerpos identificados como femeninos desafíen las normas de género. Tal y como señala Barbara Sutton (2007), la actividad de las mujeres en la explosión de movimientos sociales en Argentina a partir de los años 2002-2003 han polemizado y cuestionado las ideologías de género que asocian a las mujeres con pasividad, fragilidad y sumisión. Evocando las palabras de Butler (2009) cuando dice que no hay acción pública y política que se libre de normas generizadas, a través de poner la importancia del cuerpo en el centro de su análisis, la autora recalca que "contemporary activist embodiments do not occur in a sociohistorical vacuum. They build on a rich legacy of collective actions, which they continually draw on, contest, and reconfigure ${ }^{44 "}$ (Sutton, 2007: 137). De esta manera, a través de la ocupación de las calles (a través de técnicas performativas diversas) por las mujeres argentinas, este 'legado de acción colectiva' está siendo no sólo contestado, sino reconfigurado.

Sutton (2007) enfatiza el poder subversivo de encarnar roles que requieren fuerza física y coraje y comportamientos, mensajes y eslóganes rebeldes, ya que contradicen los estereotipos de género a través de la participación directa en movimientos sociales. Sin

\footnotetext{
${ }^{43}$ Black widows o viudas negras es el término empleado para llamar a las mujeres islamistas suicidas de origen checheno.

44 "La encarnación de activistas contemporáneas no ocurren en un vacío socio- histórico. Se construyen sobre un rico legado de acciones colectivas, en las cuales se inspiran, las rebaten y reconfiguran" (Sutton, 2007: 137).
} 
embargo, su objetivo no es indagar en el potencial o impacto de elegir técnicas performativas que hagan uso de alguna forma de violencia performativa; tema que sí aborda, la activista y académica Rodriguez Lara (2015) en el articulo "Gatazka, normalizazioa eta feminismoa".

Rodriguez Lara (2015) nos habla de las manifestaciones que son el objeto de investigación del presente trabajo. Tras la revuelta creada en torno a la performance de las mismas, señala que parte del valor de la performatividad llevada a cabo en estas manifestaciones yace en que la estética elegida abre el debate sobre la lectura feminista de lo que llamamos 'el conflicto vasco' en singular. A lo largo del artículo destaca cómo el discurso sobre el conflicto vasco está basado en estructuras binarias patriarcales que esencializan y generizan las categorías de genero, así haciendo una ecuación entre masculinidad/ hombre y violencia/guerra/ conflicto; y femininidad/ mujer y paz. Este análisis será de mayor centralidad para el presente trabajo. Además, considero que este análisis es totalmente compatible con la línea de lo dicho anteriormente sobre las implicaciones de interpretar los símbolos que hacen alusión a violencia, como fórmulas comunicativas que abren nuevas rutas de diálogo.

Aunque el análisis de Rodriguez nos ayuda a entender parte de las razones por las que la violencia performativa resulta incómoda en el País Vasco, en este trabajo me gustaría ahondar más en la performance en sí misma. Por ello, considero que el estudio que Aretxaga (1995) hace de la Dirty Portest llevada a cabo por prisionr@s politic@s de IRA en 1978-1981 resulta iluminativo para el presente trabajo. Este es un ilustrador ejemplo de cómo una performance que incomoda el discurso hegemónico de género tiene capacidad de producir y sacar a la luz situaciones que en el discurso político dominante quedan en los márgenes, es el caso de las presas políticas de IRA que en 1980 se unieron a la protesta 'Dirty Protest' (Protesta Sucia) que fue iniciada por los compañeros presos políticos en 1978 con el objetivo de protestar contra la violencia penitenciaria ejercida por el gobierno colonizador británico. Además, la Dirty Protest llevada a a cabo por las prisioneras, también alimentó el debate y división existente entre las feministas de Irlanda del norte en aquel momento.

El movimiento de liberación de Irlanda no pasó desapercibido para el debate feminista, ni tampoco la participación de las mujeres en el mismo. El argumento principal de los grupos feministas dominantes, encabezado por el Movimiento de los derechos de las Mujeres de Irlanda del Norte (NIWRM), era que al participar con el movimiento republicano, acerca del cual eran muy críticas por ser dominado por hombres, imitaban a los compañeros. Sin embargo, Begoña Aretxaga (1995) complejiza la participación de las mujeres en el movimiento Republicano, en concreto en el caso de la Dirty Protest, 
subrayando el poder de transgresión y las implicaciones políticas de la reapropiación de la Dirty Protest por parte de las presas políticas de IRA en la cárcel de Armagh.

La Dirty Protest fue una inusual forma de protesta que comenzaron los presos políticos de IRA de 1978 a 1981 en la cárcel segregada para hombres Long- Kesh. Para el caso de mi trabajo, parte de lo relevante de este caso son las reacciones que surgieron a partir de o por la participación de las mujeres en esta forma de violencia política (simbolizada a través de la sangre menstrual), reacciones las cuales Aretxaga (1995) extensamente justifica como consecuencia de la colaboración entre los discursos culturales de género, nacionalismo y política, tal y como se recoge en la siguiente cita: "if the men's Dirty Protest was incomprehensible, the women's was unthinkable, generating in many men, even among the ranks of supporting Republicans, reactions of denial $^{45 " \prime}$ (Aretxaga, 2005: 129).

Para comenzar, aunque no me puedo extender en este tema, cabe subrayar que la razón por la que los hombres comenzaron la Dirty Protest y el motivo de las mujeres es diferente. Fue precisamente un segundo caso de abuso sexual que una de las presas políticas recibió por parte un trabajador penitenciario lo que desencadenó la unión de las mujeres a la protesta, a diferencia de los hombres que denunciaban la constante humillación acompañada de incremento de violencia con relación al uso de los baños.

Como he dicho, lo que hace la Dirty Protest de especial interés es que para este trabajo, en contraste con otras formas de resistencia política como las huelgas de hambre, es la relevancia simbólica de la performance escogida: la excreta y la sangre menstrual.

Esta forma de representar su protesta política es un ejemplo de cómo esta forma de técnica performativa no es accidental e irracional, sino completamente intencional. La Dirty Protest tenía un significado consciente e intencionalidad concreta para los prisioneros. Untar las celdas con excrementos tenía sentido para la resistencia republicana, dentro del marco de la cultura nacionalista de Irlanda del norte, y I@s prisioner@s eran completamente conscientes al hacerlo. Obeyesekere hace referencia a estos símbolos que tienen significado y sentido a nivel personal y cultural como "personal symbols" (Obeyesekere, 1981, 1990 en Aretxaga, 1995: 132).

La autora sugiere que debemos entender la Dirty Protest como "a violent attempt to force such recognition without succumbing to physical elimination ${ }^{46 "}$ (Aretxaga, 1995: 133). A colación de esta cita quiero puntualizar dos cosas. Por una parte, me gusta que la autora emplee la palabra 'violento', ya que considero que coincide con lo que he definido al

\footnotetext{
${ }^{45}$ Si la Protesta Sucia de los hombres era incomprensible, la de las muejres era impensable, generando en muchos hombres, incluso entre las filas de los simpatizanetes republicanos, reacciones de rechazo" (Aretxaga, 2005: 129).

46 "un intento violento de forzar reconocimiento sin sucumbir a la eliminación física" (Aretxaga, 1995: 133).
} 
principio del capítulo como violencia simbólica. Por otra parte, porque, en la línea de mi argumento, el símbolo del excremento no es accidental y va más allá de la protesta contra la violencia penitenciaria, pues simboliza la historia colonial Anglo- Irlandesa en el ámbito socio político más amplio, lo cual deja en evidencia el poder del uso de las técnicas performativas como texto político.

Por lo tanto, la simbología elegida en esta protesta, nos hace recordar la historicidad. La Dirty Protest abre el diálogo y discurso a través de relacionar la cárcel con la violencia colonial, lo que recordemos que Manzi (2014) también señala.

Sin embargo, esto no es todo, ya que en las paredes de la prisión de mujeres, además de excreta, también había sangre menstrual. Es decir, significado adicional fue añadido cuando las mujeres se unieron a la protesta, lo que evidencia cómo el discurso general sobre la Dirty Protest se combinó con discursos de género. De esta forma, la sangre menstrual, interpretada como una señal de su naturaleza como mujeres, cambió el significado e interpretación de la protesta pues estaban sacando a la luz verdades que el Movimiento de Liberacion Radical Irlandés no quería reconocer: por una parte, la existencia y visibilidad de las presas políticas que estaban ignoradas en la conciencia popular $^{47}$ como militantes armadas y presas; y por otra parte, la opresión especifica patriarcal, que se unía a la opresión colonial. De forma concisa y en la palabras de la autora: "if the men's Dirty Protest represented the rejection of the civilizing mission of British colonialism, the Armagh [la cárcel de mujeres] women permeated that rejection with gender politics ${ }^{48 "}$ (Aretxaga, 1995: 140). Así, aplicando la perspectiva de género podemos parafrasear la siguiente cita que dice: "the Dirty Protest echoed the historical denial of British responsibility in the dynamics of violence in Ireland" (Aretxaga, 1995: $134)^{49}$ y reformularla de la siguiente manera: la Dirty Protest llevada a cabo por las mujeres hizo eco del rechazo histórico de la responsabilidad de los hombres en las dinámicas de violencia (de género) en Irlanda.

Habiendo dicho esto, el análisis de Aretxaga encaja muy bien con lo que Maialen dice que las protestas del MFV van mas allá de protestar en contra de las agresiones machistas, ya que la performance y los símbolos que evocan simbolismo nacionalista también nos recuerdan que el nacionalismo vasco ha olvidado e ignorado ampliamente el conflicto de género tras el discurso de "el conflicto vasco".

\footnotetext{
${ }^{47}$ A pesar de llevar participando en operaciones armadas y haber estado en prisión desde 1972. 48 "Si la Protesta Sucia de los hombres representó el rechazo de la misión civilizadora del colonialismo británico, las mujeres de Armagh [la cárcel de mujeres] impregnaron ese rechazo con políticas de género" (Aretxaga, 1995: 140).

49 "La Protesta Sucia hizo eco del rechazo histórico de la responsabilidad británica en las dinámicas de violencia en Irlanda" (Aretxaga, 1995: 134).
} 
Por último, además de exponer la existencia y realidad de las militantes y presas republicanas, también crearon un discurso que quedaba excluido del discurso feminista dominante. Es por ello, que Aretxaga (1995) sugiere que limitar el análisis de la apropiación de las mujeres de la Dirty Protest a puramente imitación puede ignorar que "the mimetic appropriation of the Dirty Protest entailed a process of rewriting a (hi) story of resistance, a rewriting that specified the feminine in its most transgressive form ${ }^{50 \text {, }}$ (142).

A pesar de no hacerlo de forma tan detallada como el caso recién comentado de la Dirty Protest, Rhodes (2001) en el capitulo "Women and Performative Violence" examina cómo el género es un factor que afecta tanto las motivaciones o implicaciones estratégicas, tal y como las denomina Manzi (2014); como las reacciones surgidas en torno al hecho que sean mujeres las que ejercen violencia simbólica.

No me detendré mucho en este caso ya que hacer un análisis feminista de la violencia performativa empleada por las mujeres en E.E.U.U. en los años sesenta- setenta no es el principal objetivo del autor en esta obra. Por lo tanto, a diferencia de los demás capítulos del libro en el que expone casos históricos individualmente haciendo así una lectura profunda de cada uno de ellos, en el capítulo seis reúne o documenta, de forma más bien descriptiva, casos en los que las mujeres participaron en violencia performativa. No obstante, he decidido mencionarlo pues concluye el capítulo con estas dos ideas que me parecen acertadas y que están en sintonía con lo argumentado a lo largo del capítulo.

Primero, señala que en muchas ocasiones en las que las mujeres se envolvieron en acciones políticas de violencia performativa, las razones diferían de las que motivaban a los hombres, tal y como es el caso de la Dirty Protest. Segundo, en cuanto a las reacciones en torno a los grupos feministas que decidían participar en violencia performativa, o bien quedaban eclipsados por las actividades llevadas a cabo por los hombres, o se creaban discursos desproporcionados motivados por la amenaza que suponía que las mujeres ejercieran esa modalidad de performance, en contra de las normas de género que regulan la feminidad normativa.

Trataré la performance de Pussy Riot como violencia performativa pues sus acciones son directas, pueden considerarse como conductas combativas o agresivas debido a las letras de sus canciones y el caso del ocupamiento del espacio icónico religioso de la catedral. Especialmente, porque la catedral, constituye parte de la iconografía nacionalista (Prozorov, 2014). Específicamente, "the Cathedral is a historically charged

50 "La apropiación mimética de la Dirty Protest implicó un proceso de reescritura la historia de resistencia, una reescritura que especificó lo femenino en su forma más transgresora" (Aretxaga, 1995: 142). 
space where alignments between church, state, and citizenship have been particularly exercised $^{51 "}$ (Caitlin, 2015: 50). Como caso ilustrativo de las performances del grupo Pussy Riot, describiré brevemente la performance llamada el "Christ the Savior Cathedral Punk Prayer”, es decir, la 'Oración Punk de la catedral Cristo el Salvador' por la cual condenaron a tres activistas en 2012, hecho que tuvo eco mediático a nivel internacional. Esta performance consistió en saltar al altar vestidas con vestidos de tirantes de colores, medias fluorescentes y sus emblemáticos pasamontañas de colores y tocar en directo una canción que era una fusión entre rock punk y cánticos ortodoxos tradicionales (Caitlin, 2015; Prozorov, 2014). Entre otros mensajes, en el estribillo de la canción mencionada, le piden a la virgen María que se una a la lucha feminista para luchar contra Putin.

El rechazo a analizar las políticas de las performances de Pussy Riot, es el resultado de no analizar cuidadosamente los motivos o implicaciones estratégicas de tales performances, tal y como advierten Aretxaga y Manzi. Como consecuencia de este reduccionismo, a menudo las performances de Pussy Riot son consideradas como "puro 'hooliganismo"”52 (Caitlin, 2015: 255). Traigo esto a colación porque uno de los ataques que las feministas del MFV recibieron en un artículo en el periódico Gara en septiembre del 2015 tras las manifestaciones nocturnas pre- fiestas, fue precisamente ser tachadas de hacer "feminismo punk" y ser "hooligans" (Ziga, 2015).

Aunque abordaré el símbolo del pasamontañas más adelante, primeramente, mencionaré lo que diferentes autoras identifican que ocurrió con la interpretación del discurso dominante en torno a las políticas feministas radicales de Pussy Riot. Por una parte, destacan la capacidad comunicativa de la violencia performativa como texto político; por otra, señalan cómo el rechazo por la violencia performativa ha causado que las actividades políticas de las Pussy Riot se sobresimplifiquen y desautoricen por el desafío que suponen sus representaciones (Caitlin, 2015; da Fonseca, 2015; Prozorov, 2014), de forma similar a la Dirty Protest ${ }^{53}$.

\subsection{Símbolos en la violencia performativa. Los casos del pasamontañas en las Pussy Riot y las Zapatistas}

Debido al rol transcendente que juegan los símbolos, como recordatorios culturales e históricos, considero que el símbolo del pasamontañas especialmente es de central

\footnotetext{
51 "La Catedral es un espacio cargado históricamente donde las alineaciones entre la iglesia, el estado y la ciudadanía se han ejercido de forma particular" (Caitlin, 2015: 50).

${ }^{52}$ De hecho, tres activistas fueron condenadas por "hooliganismo motivado por odio a la religión" (da Fonseca, 2015: 91-92).

${ }^{53}$ Para leer más sobre el proceso de desautorización y simplificaicon de las políticas de Pussy Riot, ver Caitlin, 2015; da Fonseca, 2015.
} 
importancia a la hora de querer comprender los debates surgidos en torno a las protestas de estética combativa del MFV. Como he justificado en el primer capítulo, el pasamontañas puede considerarse identificativo de las protestas del MFV. Pienso que es un símbolo poderoso y que merece atención particular, por lo que, recogeré una breve mención al significado que otros movimientos sociales le han dado a este símbolo, concretamente, las Pussy Riot y el Ejército Zapatista de Liberación Nacional.

Uno de los elementos que hace saltar la alarma en las actuaciones de violencia performativa, son los símbolos, los cuales Obeyesekere (1981, 1990 en Aretxaga 1995) denomina como personales, ya que son relevantes por su significado a nivel personal y cultural. Debido a los objetivos del presente trabajo, me centraré, en la línea del análisis de Aretxaga, en el poder del uso de símbolos con concretos significados culturales e históricos, lo que Manzi (2014) relaciona a través de la relación de las performances con rituales. En el caso de la Dirty Protest, son las heces y la sangre menstrual los símbolos encadenantes de reacción y mensaje político: símbolos que en el caso de las presas que se unieron en la Dirty Protest se mezclaron para hacer evidentes opresiones que se intersectan. En el caso de las manifestaciones del MFV, son los pasamontañas, el fuego y la vestimenta negra (Rodriguez Lara, 2015) los símbolos que desencadenan el debate en torno a esta forma de estética. Como Aretxaga y Manzi señalan, la violencia performativa junto con protestar políticamente acerca de una problemática puntual, nos sitúan en una historicidad particular a través de los símbolos culturales. Además, otro del carácter subversivo de esto, es que señala aspectos de la historia que el discurso dominante (intencionalmente) ignora, tal y como la opresión patriarcal de dentro de la nación.

Caitlin (2015) señala que el icono o símbolo del pasamontañas no ha sido empleado exclusivamente ni por primera vez por el grupo feminista ruso Pussy Riot, y menciona antecedentes manifestaciones en las que se optó por cubrirse la cara, como por ejemplo, la manifestación en Seattle en contra de la OMC Bloque Negro en 1999, la Másara de Guy Fawkers y la Pimavera Árabe.

A pesar de encontrar abundantes trabajos sobre las representaciones de las Pussy Riot, sus políticas feministas y el eco y solidaridad transnacional surgida tras su principal performance en la catedral, indicaré como el pasamontañas es utilizado como herramienta para combinar sus demandas políticas y su práctica artística en su acción política feminista directa ${ }^{54}$. Diversos análisis sobre las performances de las Pussy Riot, a través de su actitud "desafiante, su postura política, protesta artística y música punk,

\footnotetext{
${ }^{54}$ Lo cual da Fonseca (2015) señala que es una de las características del activismo de la Tercera Ola del Feminismo, como el movimiento Riot Grrl.
} 
Pussy Riot son consideradas como una continuación de la tradición femenina de empoderamiento que emergió con las Riot Grrls" (Schwartzman \& Maillet, 2013:180 en da Fonseca, 2015: 95). Dicho de otra forma, su performance, la cual incluye su combativo atuendo, estética, símbolos, música y las letras, es su herramienta para transmitir su mensaje político.

Por último, el uso del pasamontañas, lejos de pasar desapercibido en el caso del movimiento zapatista, se considera el símbolo que representa al movimiento. Sin embargo, este símbolo no queda absuelto de controversia, por lo que Cortés Baeza (2014) hace un análisis interesante sobre la producción fotográfica del movimiento, señalando así que el uso del pasamontañas pasó de tener una función instrumental a una estética, poética. Más concretamente, la autora sugiere que a través de la producción gráfica y discursiva, se volvió, desde el uso utilitario para ocultar el rostro y representar la horizontalidad del sistema organizativo del grupo, a lo estético a través de resignificar el sentido convencional y original. Debido a la relación de los símbolos del pasamontañas y paliacate a la imagen del terrorista tanto en el imaginario popular, como en discurso de la oposición, el grupo resignificó estos símbolos al exhibir la posibilidad de convivencia entre diversos lenguajes y significados. De esta manera, "lo mítico, lo indígena, lo ingenuo, lo natural, lo revolucionario, han envuelto al ocultamiento y lo han resignificado desde sus discursividades" (Cortés Baeza, 2014: 164).

Lo que quiero destacar de este análisis de los pasamontañas y paliacates que se consideran como los símbolos más representativos del neozapatismo, es la "potencia estética del pasamontañas" (Cortés Baeza, 2014: 11, 81), lo cual será de interés para el capítulo etnográfico.

He intentado exponer convincentes argumentos que no sólo evidencian que las normas de género informan sobre lo que y cómo puede aparecer en el espacio público (Butler, 2009), sino que cuando aquello que se performa coge forma de violencia simbólica, el potencial político es grande pero también complica el análisis si no se hace una lectura profunda de los objetivos, símbolos y postulados políticos de base.

Indicaría dos potencialidades de la violencia performativa y simbología empleada en las mismas como forma de acción política. Por una parte, se convierte en un texto político y como en el caso de la Dirty Protest y las manifestaciones del MFV, al utilizar símbolos personales, a los que yo también quiero llamar como símbolos culturales, nos recuerdan y sitúan en un marco histórico y cultural concreto, lo que hace que el mensaje de la performance vaya más allá de la demanda explícita. 
Cuando además de analizar la violencia performativa en sí misma, prestamos atención a las reacciones y discursos generados a su alrededor, es entonces cuando se cristalizan la influencia de las normas de género que regulan tanto el espacio publico/político y quién y cómo puede aparecer en él. 


\section{AGENCIACIÓN DE TÉCNICAS PERFORMATIVAS DE LA VIOLENCIA}

Tal y como he mencionado repetidas veces a lo largo de los capítulos previos, las manifestaciones que hacen uso de lo que Medeak (2015) denomina "técnicas performativas de la violencia", tenían el objetivo explícito de crear debate, como se recoge en una de las citas más adelante en este capítulo. Satisfactoriamente con este inicial objetivo de las propulsoras (Farrukas) de esta modalidad de acción política o manifestaciones, el debate se ha creado. Por nombrar algunas de las reacciones contrariadas ante esta estrategia política, podemos mencionar los artículos de las activistas feministas Monroy (2015) y Ziga (2015), la cual emplea lenguaje connotativo del calibre de "hooligans". Sin ignorar las campañas de desprestigio dirigidas al MFV desde sectores anti- feministas, tal y como la denuncia a dos activistas gasteiztarras en 2015, por mencionar un caso.

Me interesa hacer una lectura profunda de los objetivos y potencial políticos de las representaciones que se agencian del miedo y símbolos de violencia, con el objetivo de tener una comprensión más compleja de la corriente que legitima y la que simultáneamente muestra resistencias en torno a la acción política que emplea el miedo y símbolos de la violencia. Es por ello, que uno de los objetivos de este trabajo, es analizar de cerca las representaciones y técnicas performativas, prestando particular atención a las "implicaciones o motivaciones estratégicas" (Manzi, 2014) de las personas que las organizan.

A diferencia de autores como Rhodes o Manzi que han analizado el uso de violencia performativa como estrategia política, los cuales no introducen la categoría de análisis de género como principal eje analítico, yo me valdré de análisis realizados tanto por Begoña Aretxaga, Gayatri Spivak y Judith Butler con el objetivo de introducir tanto el género como el contexto socio- político e histórico y cultural vasco

Sin embargo, esto no es sencillo, ya que en el análisis de la performance como herramienta política, introduciré cómo el género y el contexto socio- político e histórico y cultural vasco tienen cargas simbólicas relevantes que se enredan con los discursos y políticas feministas de mi objeto de estudio.

\subsection{Pensamiento transfeminista y bollero y acción directa: las políticas desde dónde surge la estética de la violencia como estrategia política}

"Me defino como feminista radical y bollera, y creo que esto también condiciona de lleno los enfoques desde los que hago, obviamente, el activismo ¿no? Porque no todo el activismo feminista es radical y no obviamente todo el activismo feminista es bollero 
¿no? Entonces digamos que para mi estos son los dos ejes principales" (Maialen, 2017). Así comenzamos la entrevista Maialen y yo, y así es como quiero comenzar también los capítulos en los que tengo como objetivo poner en debate una lectura profunda del uso de la violencia performativa como estrategia política para responder a las agresiones machistas en Euskal Herria.

De acuerdo con Maialen y como también lo enfatizan las demás activistas entrevistadas, debido a la importancia de entender desde dónde observamos, entendemos y analizamos, por tanto, desde dónde actuamos, es decir, nuestra lectura situada, considero imprescindible comenzar por presentar en más profundidad los colectivos feministas (transfeministas) los cuales han elaborado un discurso y práctica política en torno al uso de "técnicas performativas de la violencia" en Euskal Herria. Así, en otras palabras, trataré de prestar atención a las "implicaciones estratégicas o motivaciones" (Manzi, 2014) que guían y articulan el uso de violencia performativa en este primer apartado.

Con el objetivo de exponer el marco interpretativo desde el cual proponen la estrategia política de la violencia performativa, algunas activistas también enfatizan el feminismo desde donde se hace este planteamiento. El colectivo Oihu K, es un colectivo transfeminista autónomo y el único espacio ocupa (en Recalde) no mixto de Euskal Herria, ocupado por bolleras, trans y mujeres. Betize, la activista de Oihu K con la que estuve en contacto, se identifica como bollera transfeminista, posicionamiento que considera que tiene un gran poder político y que influye sus perspectivas debido a las experiencias que le atraviesan como tal. Con respecto al transfeminismo, lo define de la siguiente manera:

"Beste genero identitade anitzak ikustarazten dituen feminismo mota. Ez dut esan nahi feminismoak orain arte ikusi izan ez dituenik, baina bai uste dut eh arrazializatuak diren emakumeak bezala, emigranteak diren emakumeak bezala, dibertsitate funtzionala duten emakumeak bezala, ez zaiela, gure euskal kontestutik behar adina ez igual... arreta ez? Ez dugula jakin nola hurbildu jende honetara. Edo beti hori, "la otredad" "los otros". Haiek dira transak, ez ditugu inoiz ikusi gure artean dauden pertsonak bezala. Bollerekin ere hori gertatu da, feminismoan, bazeuden talde bolleroak, ez bolleroak... egon dira, bueno

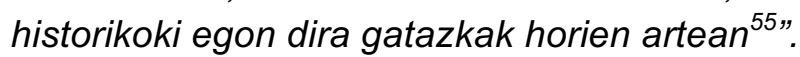

\footnotetext{
55 "Un tipo de feminismo que visualiza las identidades de género diversas. No quiero decir que el feminismo hasta ahora no las haya visto, pero sí que creo que a las mujeres como a las mujeres racializadas, a las mujeres emigrantes, mujeres con diversidad funcional, no se les ha prestado suficiente atención desde nuestro contexto, ¿no? No hemos sabido cómo acercarnos a esta gente. O siempre, eso, "la otredad", "los otros". Elles son transes, no les hemos visto como personas que están entre nosotras. Con las bolleras también ha ocurrido eso, en el feminismo había grupos bolleros, no bolleros... pues bueno históricamente ha habido conflicto entre esas [identidades].
} 
Medeak también se sitúa dentro del transfeminismo, que considera como "una corriente interna del feminismo" (2014: 74) y el cual entiende que posibilita descentrar el sujeto político de mujer blanca heterosexual, en consonancia con Betize. En palabras de Iraultza, "me situo dentro del Movimiento Feminista de Euskal Herria y mucho desde pensamiento transfeminista y bollero y también mucho en la acción directa". Como se puede observar en las dos últimas citas, aunque ambos grupos se sitúan dentro del MFV, también enfatizan aquellos ejes que consideran les dan matices situados a su acción política.

A través de la especificación de su paradigma transfeminista, identidad de bollera y promotoras de la acción directa, también emplean términos como "feminismo autónomo", "sujetos en los márgenes", "suburbios" para enfatizar su desvinculación a feminismos institucionales o conciliadores e incluso utilizan la palabra "bonito": "dago

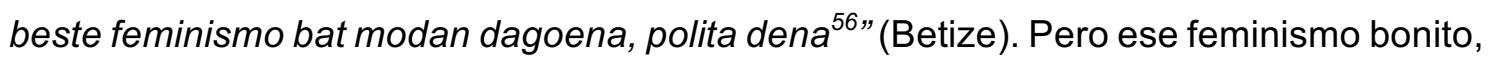
no es el suyo. Así, las tres indican que estas manifestaciones vienen del feminismo autónomo, anti- sistema ("gu [feminismoko] suburbioetatik gatoz"), es decir, de los suburbios del feminismo, de una cultura feminista diferente al feminismo hegemónico. Betize subraya el carácter autónomo de los colectivos como Oihuka y Farrukas, y dice que "niretzat Farrukak Iruñean egin zutena, o sea, izan zen errealitate kultural feminista

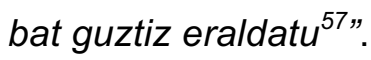

Tal y como indica Maialen en la cita con la que abro este subapartado, esta localización política tiene todo que ver con los análisis y las estrategias políticas propuestas en consecuencia por este sector del MFV.

En cuanto a FARRUCAS, en su blog se presentan como "un grupo intergeneracional, heterogéneo y autónomo que al juntarnos y compartir estamos creando herramientas de empoderamiento y de lucha" (FARRUCAS, 2014). Ante la identificación de la necesidad de dar una respuesta más contundente y radical a las agresiones machistas sistémicas ante "Sanfermines cronificados con violencias sexistas muy fuertes" (Iraultza), proponen lo siguiente:

"Nuestra apuesta, desde el primer momento, es salir juntas a la calle a denunciar y responder la violencia machista, siendo y haciendo aquello que nos es negado: ir encapuchadas, vestidas de negro, con antorchas, haciendo ruido, expresando rabia, con fuerza... Transgredimos la imagen de mujer víctima, sumisa, pasiva y

El problema, la cosa es, que "la otredad", "la alteridad", no somos nosotras. Y no, por qué no hay entre nosotras, de hecho, desde que ha ocurrido el auge del transfeminismo, de repente está apareciendo gente trans a nuestro alrededor. No, no están apareciendo, siempre han estado ahí. La cosa es que ahora las estamos visualizando".

56 "Hay otro feminismo, otro feminismo que está de moda, que es bonito".

57 "Para mi lo que hizo Farrukas en Iruña fue, o sea, transformar totalmente una realidad cultural feminista". 
nos mostramos activas y combativas, siendo conscientes de nuestro poder y de nuestra fuerza" (FARRUCAS, 2016).

Esta cita recoge no sólo la performatividad que representará la forma de su protesta, sino que también nos deja ver las ideas políticas que sustentan tal decisión, entre otras, la legitimidad de responder, la autodefensa y rechazo al estereotipo esencialista de las mujeres como pasivas y carentes de rabia y agresividad. La promoción de la autodefensa feminista como respuesta a las violencias machistas, surgen de un análisis político de la violencia machista muy concreto. Dicho de otra manera, la estrategia política que propone agenciarse del miedo, va en coherencia con la evaluación contundente de cómo y por qué se llevan a cabo las violencias machistas:

"el miedo va a cambiar de bando es el lema que concienzudamente hemos elegido como estrategia política, sabiendo que es provocador y no conciliador, porque, precisamente, queremos generar debate" (FARRUCAS, 2016).

Es decir, a través de estas manifestaciones, no se busca conciliación, hacer las paces, conformidad, acuerdo, armonía, convenio. Como también indica el grupo Medeak (2015), no aceptan la concepción de "paz" o contrato que construyen los hombres entre los hombres, sobre la opresión sistémica machista (Goikoetxea, 2015) ${ }^{58}$. Tal y como dice Betize, "no es que hagamos apología de la violencia", sino que se deja al descubierto que esa "paz" esconde la normalización de la violencia. Cuestionar el ordenamiento y sistema que, efectivamente garantiza paz (parcial), la de los hombres (a lo que también debería añadir raza, clase e idioma en el caso de Euskal Herria), es una declaración molesta en general, pero recordemos que además, estas manifestaciones se dan en momentos y espacios de celebración o festivos.

Por lo tanto, el empleo de técnicas performativas de la violencia surgen de una planteamiento que definen las violencias machistas como una guerra, es decir, un conflicto:

"hau guda bat da. Es que jendea ez da konturatzen. O sea gudan gaude, estamos en una puta guerra. (...) kontua da normalizatuta dagoela, girotuta dagoela, gure kulturan ezarrita dagoela, eta horren kontra egitea, subversiboa da. Ez dago ondo ikusia, ez da idilikoa ez ? $^{59 "}$ (Betize).

De acuerdo con la concepción de la violencia machista como guerra y empleando así un campo semántico similar, Medeak (2015) también indica lo siguiente: "queremos recordarle al mundo que nosotras estamos en guerra contra el sistema heteropatriarcal". Partiendo de esta lectura a través de la cual explican la violencia machista como un

\footnotetext{
${ }^{58}$ Recuerdo que este argumento también es compartido por el EHBF, lo cual señalaron en el manifiesto que publicó en junio del 2016 previamente a la temporada de fiestas populares del verano.

59 "Esto es una guerra. Es que la gente no se da cuenta. O sea, estamos en guerra, estamos en una puta guerra. (...) la cosa es que está normalizado, está ambientado, está culturalmente arraigada, y reaccionar en contra de eso, es subversivo. No está bien visto, ¿no es idílico no?".
} 
campo de batalla, y la violencia como herramienta, surge la teoría de la autodefensa como herramienta ${ }^{60}$.

Este enfoque interpretativo que ofrece el transfeminismo sobre la violencia sexista, nos lleva al origen del término acuñado por Medeak de la reapropiación de "las técnicas performativas de la violencia" (2014: 78). Este planteamiento surgió durante unas jornadas organizadas por Medeak y Garaipen ${ }^{61}$ en 2009 con el objetivo de re- pensar el concepto de violencia sexista (Medeak, 2014; Iraultza). Aquí enfatizaron "las múltiples caras de las violencias sexistas", sin negar las que ocurren dentro de las relaciones heterosexuales, pero sin limitarlas a éstas. Así, Paul B. Preciado, en aquel momento Beatriz Preciado, ya que Medeak trabaja el DragKing, Preciado "hizo un paralelismo: qué es la violencia, como se inscribe la masculinidad, es puro teatro al final ¿no? Aunque luego tenga efectos físicos y reales, la performatividad, o el poder tener ese acceso a la violencia es una performance". Rescatando esta idea que lanzó Preciado, Medeak desarrolló la idea de la violencia performativa como forma de respuesta ante las agresiones. Sin embargo, desde Medeak, aún no habían encontrado la manera de llevar esta idea a la práctica, hasta que Farrukas propuso las manifestaciones nocturnas:

"Es una idea que lanzó [Preciado] en modo abstracto y en un seminario de 4 horas. Nosotras lo rescatamos, y queriendo bajar un poco a hechos más prácticos, le veíamos bueno un potencial de repensar cómo se nos había expropiado a las mujeres la violencia, y el uso de ella.

Pero luego eso cómo lo llevas a la práctica, o más a nivel de movimiento social, en este caso feminista.

En ningún caso teníamos en mente por ejemplo las manis nocturnas. Salen de otro lado, pero viene a ser eso ¿no?” (Iraultza).

Esta cita tiene mucho material que analizar al que dedicaré el próximo punto. Pero englobando esta idea con lo que he venido desarrollando en este punto, desde este paradigma político, la promoción de la acción directa a través del empleo de técnicas performativas de la violencia surge de la identificación de necesidad de "pasar de la defensiva a la ofensiva" (Hodei). Además recordemos la cita de Farrucas (2016) en la que subrayan el objetivo de transgredir "la imagen de mujer víctima, sumisa, pasiva y nos mostramos activas y combativas, siendo conscientes de nuestro poder y de nuestra fuerza"62, representación que relacionan con la capacidad de pasar del imaginario de mujer victima, a mujer sujeta política activa.

\footnotetext{
${ }^{60}$ Betize menciona el libro "Queer Ultraviolence" y la fanzine Manifesto SCUM que comenzaron a desarrollar estas ideas en EEUU, Europa y ciudades de España como Madrid y Barcelona.

${ }^{61}$ Garaipen es una organización multicultural feminista de Donostia.

62 En el siguiente apartado desarrollaré más en cómo el empleo de violencia performativa contribuye a demostrar y promover la capacidad de respuesta de las mujeres como sujetas activas.
} 
En definitiva, las activistas entrevistadas y las publicaciones de los colectivos mencionados demuestran que ha habido una elaboración minuciosa del análisis y discurso político sobre las violencias machistas a las cuales se les ha y está respondiendo, por parte de un sector del MFV por medio de la estrategia política de la violencia performativa. Por lo tanto, a lo largo de los siguientes puntos trataré estas acciones políticas como formas de acción directa deliberadamente articuladas y cuidadosamente construidas como "un intento coherente de abrir líneas de comunicación con la sociedad" (Rhodes, 2001: 187). Además, pondré el foco en la función de las técnicas performativas. Indagaré sobre la articulación de la violencia performativa a dos niveles: por una parte, exploraré la parte más política para entender el por qué y para qué la agencicación de las técnicas performativas de la violencia a través de las entrevistas y textos; por otra parte, trataré de mostrar cómo se agencian el miedo y las técnicas performativas basándome en la interpretación de la estética, las imágenes y los lemas.

\subsection{Agenciación del miedo y técnicas performativas de la violencia como estrategia política}

"A nosotras se nos inculca el miedo y, encima, se nos niega la
agresividad. Nos reapropiamos de ella, porque es una
herramienta muy útil para responder, para poner límites, para
decir que no, para hacernos respetar. Queremos y apostamos por
transformar ese miedo en respuesta activa, afirmativa y
combativa" (Farrukas, 2016).

El miedo como herramienta y su apropiación es una de las bases de la estrategia que propuso Farrukas, como se recoge en una de las citas anteriores. ¿Qué potencial político tiene la agenciación del miedo? ¿Qué análisis yace tras la agenciación del miedo como estrategia política?

"Lo que se hace a través de la violencia es intentar asustar a las mujeres. El miedo es la estrategia de la violencia", es lo primero que me dice Hodei cuando le pido que me explique cómo entiende la agenciación del miedo como estrategia política. En otras palabras, "el miedo es una herramienta. Una herramienta que el patriarcado, los poderosos, siempre han utilizado. Pues ahora lo que hemos querido conseguir a través de estas manis o performances, o lo que propusieron desde Iruña, es que nosotras cojamos esa herramienta. Siempre ha sido esa herramienta que han usado contra nosotras, ahora la cogemos nosotras, bueno la vamos a coger"63 (Betize).

63 "beldurra erraminta bat da. Patriarkatuak, boteredunek, beti erabili izan duten erraminta. Ba orain performance edo mani hauekin lortu izan duguna, edo Iruñatik proposatu zuten erraminta hau, hau da, guk hartzea erraminta hori erabiltzea. Beti izan 
Primeramente, desenmascaran cómo el miedo funciona como herramienta en el sistema de la violencia sistémica sexista, concretamente, cuando se trata del miedo a la violación o agresión sexual. Es decir, identifican y sitúan el papel que juega el miedo y, muy importante, se le pone nombre al sistema, grupo e individuos que ejercen ese miedo. Coinciden con Virgini Despentes (2007) en el siguiente análisis:

"Una empresa política ancestral, implacable, enseña a las mujeres a no defenderse. Como siempre, doble obligación: hacernos saber que no hay nada tan grave [como la violación], y al mismo tiempo, que no debemos defendernos, ni vengarnos. Sufrir, y no poder hacer nada más" (39-40).

De esta manera, el miedo sin agencia es una herramienta para mantenernos en nuestra postura de víctimas indefensas, como indica la cita de Despentes. Por ello, Medeak propone la agenciación del miedo ya que si no, el miedo se vuelve una herramienta del patriarcado: "una de las propiedades más esenciales que hace que las mujeres seamos mujeres, no son los genitales, es que estemos condenadas a vivir con miedo" (2014: 76).

Al señalar que el miedo ha formado parte de lo que se nos ha inculcado a las mujeres desde la socialización temprana, desnaturalizan la idea de que el miedo es una cualidad inherente experimentada (pasivamente) por las mujeres y ejercida (activamente) por los hombres. La posición de receptividad subraya la posición pasiva, en oposición a generadoras activas, en la que se sitúan a las mujeres: "nos han educado para que seamos receptoras de miedo ${ }^{, 64}$ (Betize). En la misma línea, Maialen piensa que:

"es interesante esa idea de que el miedo cambie de bando porque el miedo, la culpa y demás es algo que nos lo han educado a las mujeres y nos han obligado a socializarnos con ellos. Entonces cuando se pide que el miedo cambie de bando, no se está diciendo que los hombres tengan que tener miedo, sino que sean conscientes por un segundo de lo que sucede con el miedo. Hasta qué punto el miedo condiciona nuestra vida y también a la vez cuando nosotras decimos que nosotras no vamos a tener ese miedo, lo que estamos diciendo es lo liberador que es no ser ese sujeto oprimido" (Maialen).

Como resultado de esa socialización, y como señala Maialen al final de la cita, el miedo está presente y afecta de forma directa la vida de las mujeres. Es decir, el miedo como herramienta del patriarcado tiene implicaciones directas y relación directa desde la construcción de la identidad hasta las formas en las que ocupamos el espacio. Por supuesto, sin querer decir que esto sea en todos los casos totalizador y paralizador,

da gure kontra erabili izan duten erraminta hori, orain guk hartu dugu, bueno guk hartuko dugu" (Betize).

${ }^{64}$ Cita original: "uste dut beldurraren hartzaileak izateko hezi izan gaituztela". 
pero que está presente, y estas activistas lo relacionan a la representación pasiva de las mujeres.

Sin embargo, el planteamiento de estas manifestaciones no se limita a lanzar lemas provocativos para promover la reflexión sobre el miedo y quedarse ahí, sino que dan un paso hacia la acción directa a través de la performance o técnicas performativas. Concretamente, ejecutan o performan el discurso, es decir, ejercen aquello que reclaman a través del discurso (Butler, 2007). Identificar cómo opera el miedo como herramienta opresiva no es suficiente para comenzar a introducir cambio en los comportamientos reales y cotidianos. Es por ello que realizar talleres de autodefensa y promover la respuesta no es suficiente mientras sigamos siendo o considerándonos a nosotras mismas como "cuerpos expropiados como generadores de violencia o de fuerza en un momento dado" (Iraultza).

El empleo de técnicas performativas permiten el salto de demandas políticas discursivas y abstractas, a la escenificación de valores como la agresividad, violencia o fuerza que las mujeres no estamos habituadas a experimentar en nuestros cuerpos:

"Kontua da azkenean erraminta hori guk erraminta hori berenganatzea. Eta ez dugu zertan apologia de la violencia egiten, baizik eta erabiltzen baduzue gure kontra, erantzungo dugula, eta ez garela subjektu pasiboak izango ${ }^{65, "}$ (Betize).

En otras palabras, proponen la agenciación del miedo como forma de invertir la posición que se asigna a través de roles femeninos a las mujeres en relaciona situación de violecias machistas: es decir, la agenciación del miedo como estrategia para "pasar de la defensiva a la ofensiva" (Hodei).

\subsection{Performance del miedo y violencia simbólica}

En el apartado anterior he indagado en las motivaciones y explicaciones políticas de las activistas para apropiarse de técnicas performativas de la violencia, pero, ¿cómo se agencian de la violencia performativa como herramienta política? ¿Cómo se escenifica o a través de qué símbolos o medios performativos?

Considero que es la performance que engloba estética, lenguaje, símbolos y representación corporal la que tiene la capacidad de transmitir el espíritu combativo y la agenciación de miedo, agresividad y violencia. Es el poder de todos estos elementos performativos (el negro, el pasamontañas, el fuego, eslógaes directos y combativos, ocupación de espacio) en conjunto los que movilizan ideas de miedo.

\footnotetext{
65 "La cosa es al final que nosotras empleemos esa herramienta. $Y$ no tenemos por qué hacer apología a la violencia, pero si la utilizáis en contra de nosotras, vamos a responder, y que no vamos a ser sujetas pasivas"
} 
Con el objetivo de hacer un análisis profundo, comenzaré basándome en la incorporación de las técnicas performativas de la violencia y en cómo el conjunto de la performance se agencia de la violencia simbólica y el miedo en la manifestación nacional "11 eraso, 12 erantzun ${ }^{66}$. Vuestras Violencias Tendrán Respuesta. Feministok Prest!" del 2016.

Imagen 7: El Cartel del Programa de la Manifestación Feministok Prest

Primeramente, la noche y el espacio público constituyeron uno de los ejes principales de la manifestación, continuando así lo trabajado localmente por grupos feministas durante las fiestas populares y siguiendo la línea de trabajo de las manifestaciones nocturnas de los años 2014 y 2015. Bajo este pilar ideológico, en la protesta se quiso reivindicar que:

"la noche y las fiestas son un potencial espacio para la violencia. Con el pretexto de la nocturnidad, el alcohol y la permisividad, se multiplican las agresiones sexistas contra nosotras. Mientras que para unos las fiestas son espacios de ocio y desinhibición, para otras son lugares de agresiones, exclusión y trabajo" (Feministok Prest, 2016)".

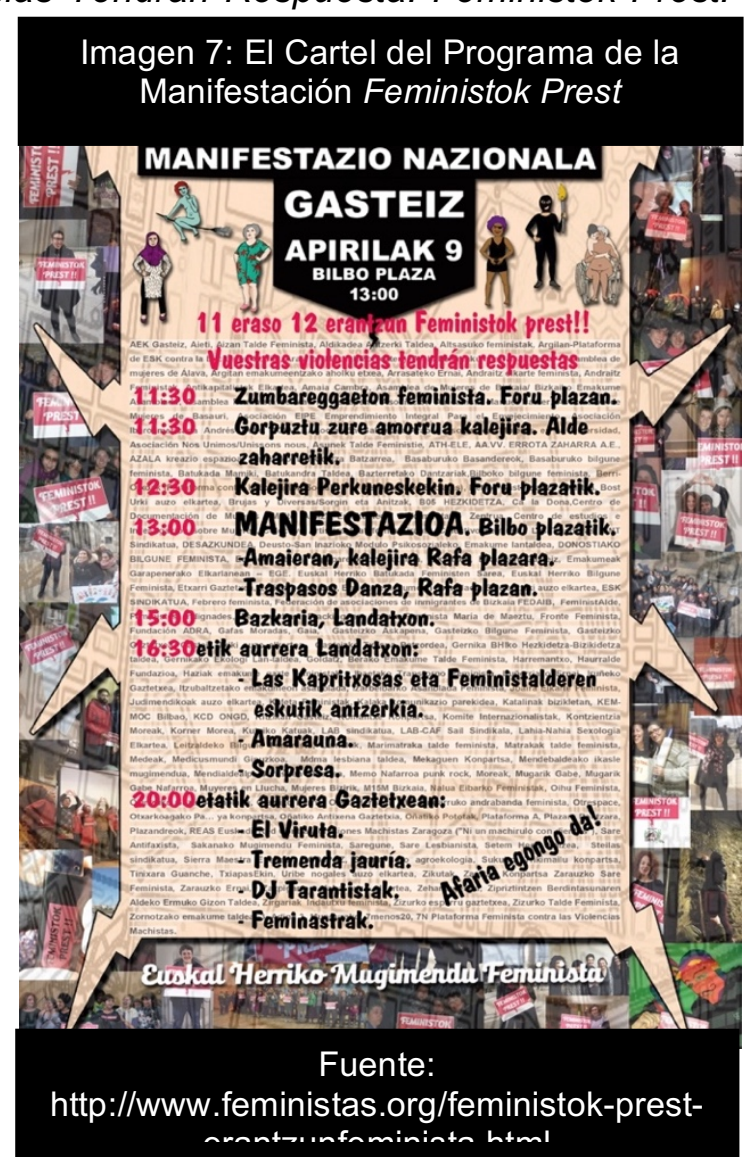

Más allá de que la noche y el espacio público sean una de las bases políticas de la protesta, lo que coincide con los análisis políticos reunidos en el apartado 5.2., sugiero que la apropiación de la violencia simbólica se muestra ilustrativamente en la performance y simbolismo que se llevó a cabo durante el pasacalle "Gorpuztu Zure Amorrua/ Encarna tu enfado" que desembocó en la manifestación y en el cartel que anunciaba el evento (Imagen 7).

${ }^{66} 11$ agresiones, 12 respuestas en castellano. 
En cuanto al "pasacalle encarna tu rabia/enfado", fue propuesto por los colectivos FARRUKAS de Iruña y Oihuka de Bilbo, con intención de incluir la violencia performativa como una de las formas de representación del MFV, cuya estética podemos apreciar en las imágenes 8 y la foto de la derecha de la imagen 8. El lema principal ("11 eraso, 12

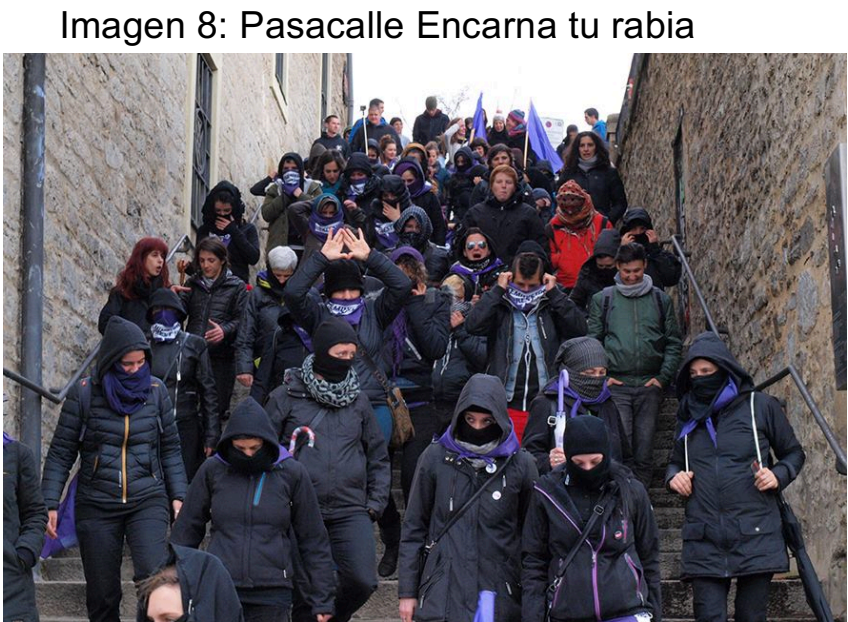

erantzun. Vuestras Violencias

Tendrán Respuesta. Feministok Prest!") ya indica que el movimiento feminista esta listo, preparado para actuar, responder, y el pasacalle muestra que una de las formas de respuesta va a ser a través de la agenciacion de las técnicas de la violencia.

¿Cómo se representa o agencia la violencia simbólica? En la misma línea de las manifestaciones pre- sanfermines y preSemana Grande en Bilbo y Donostia, las participantes de la manifestación en Gasteiz iban vestidas de negro y algunas con la cara cubierta por un pasamontañas o similar, como se puede apreciar en las imágenes 8 y 9 .

A pesar de haber enfatizado el conjunto de la performance como herramienta para agenciarse de la violencia Imagen 9: : Pasacalle Encarna tu rabia performativa, pienso que el símbolo del pasamontañas juega un rol muy central como transmisor de enfado, potencial generador de violencia y actitud no reconciliadora. Aunque pasamontañas pueda producir ideas de miedo en distintos contextos, opino que su poder como movilizador de temor es particularmente poderoso en

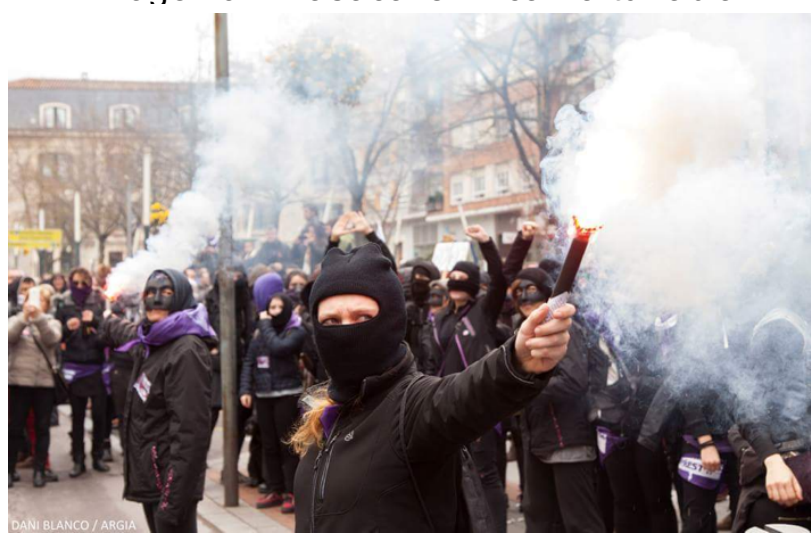

Fuente: Blanco, 2016. Argia Euskal Herria, ya que, como indica Betize, "beldurra dago, buru berokia sinbolo potentea da Euskal Herrian: beldurra, terrorismoaren, biolentziaren ikurra da ${ }^{67 "}$. En el apartado 6.1. desarrollaré un análisis contextual del símbolo de pasamontañas más en profundidad y en el 5.4. en relación a las normas de género.

A nivel discursivo, emplean campos semánticos en los lemas y eslóganes relacionados

\footnotetext{
67 "hay miedo, el pasamontañas es un símbolo potente en Euskal Herria: es el símbolo del miedo terrorismo, violencia".
} 
a emociones como rabia, enfado, hartazgo. Por ejemplo, los eslóganes que cantaban ${ }^{68}$ iban de la mano de la intencionalidad descrita hasta ahora, haciendo uso así de lenguaje directo y combativo, como "machistas cabrones, a los tiburones", lo cual refuerza el miedo creado por la imagen de personas encapuchadas, pues no queda lugar a interpretación: el mensaje es directo, y el lenguaje identifica a los sujetos a los que se dirige y convierte a los agresores en objetos recibidores de miedo, en lugar de ser los ejercedores de ese miedo.

5.3.1. El símbolo del pasamontañas: icono de continuidad y legitimación del MFV Al hilo del símbolo del pasamontañas, hago otra lectura de cómo el pasamontañas juega un papel de cohesión o continuidad dentro del MFV. Concretamente, interpreto la incorporación del símbolo del pasamontañas como identificador de las protestas en contra de agresiones machistas en fiestas populares. En otras palabras, sugiero que la integración del símbolo del pasamontañas como icono de las manifestaciones en contra de agresiones y del discurso directo (eslóganes), los cuales podemos encontrar en diferentes manifestaciones locales, por una parte, constituyen continuidad y unión entre los grupos del MFV; y por otra parte, también puede considerarse como una forma de legitimar esta forma de representación para responder a las agresiones.

La incorporación de simbología, iconos y recursos discursivos puede apreciarse en numerosas manifestaciones locales. Instancia de ello son el cartel de Feministok Prest! (Imagen 7) en la parte superior derecha del cartel, así como la reciente manifestación en el barrio Iretargi de Barakaldo, por proponer un caso diferente a las capitales vascas. En la Imagen 10 que corresponde a la mencionada manifestación en Barakaldo, podemos ver el empleo de tres cabezas encapuchadas como icono de la lucha contra las agresiones machistas.

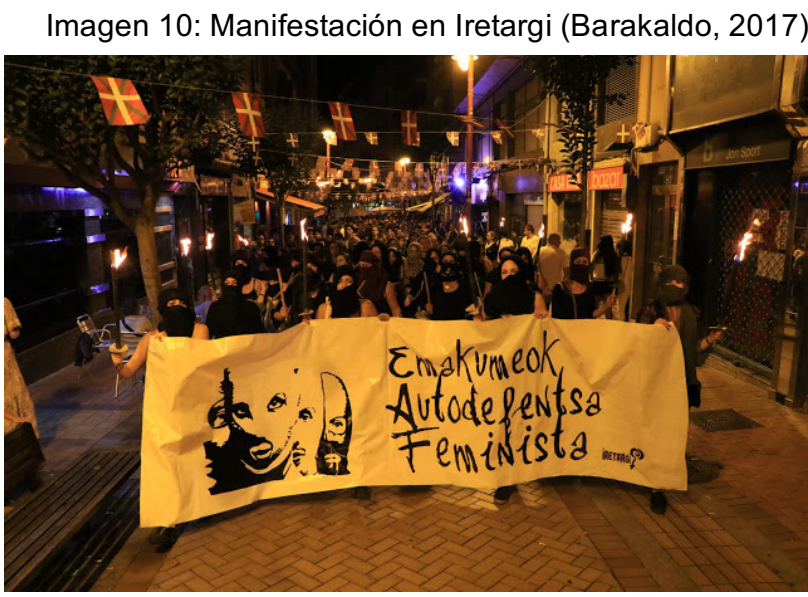

No obstante, también me gustaría hacer mención a la incorporación icónica y simbólica del pasamontañas en la lucha contra las violencias sexistas de forma más amplia y no exclusivamente en las protestas.

Como se puede observar en la imagen 11, organizaciones relevantes dentro del MLNV también han

\footnotetext{
${ }^{68}$ A través del siguiente link se puede acceder al video que recoge imágenes de la manifestación donde se oyen los eslóganes como el recogido en esta página: https://www.youtube.com/watch?v=WXdFfZ3XKV0
} 
aportado por la propuesta de la agenciación de la violencia performativa como una forma de acción feminista.

Como resultado del trabajo del feminismo, en los últimos años Ernai, la organización independentista, socialista y feminista del MLNV, ha apostado por introducir nuevos imaginarios y elementos en sus carteles, los cuales contribuyen a deconstruir el imaginario del guerrero masculino y heterosexual, entre los cuales, encontramos la integración del símbolo del pasamontañas llevado por mujeres (Rodriguez, 2016). Esto puede considerarse como una contribución a la legitimación de la lucha del MFV, ya que se adhiere a a la propuesta bajo el lema "El Miedo Va a Cambiar de Bando".

Imagen 11: Portada de Emaraun, Poster de Ernai y Manifiesto de EHBF de $2016^{69}$
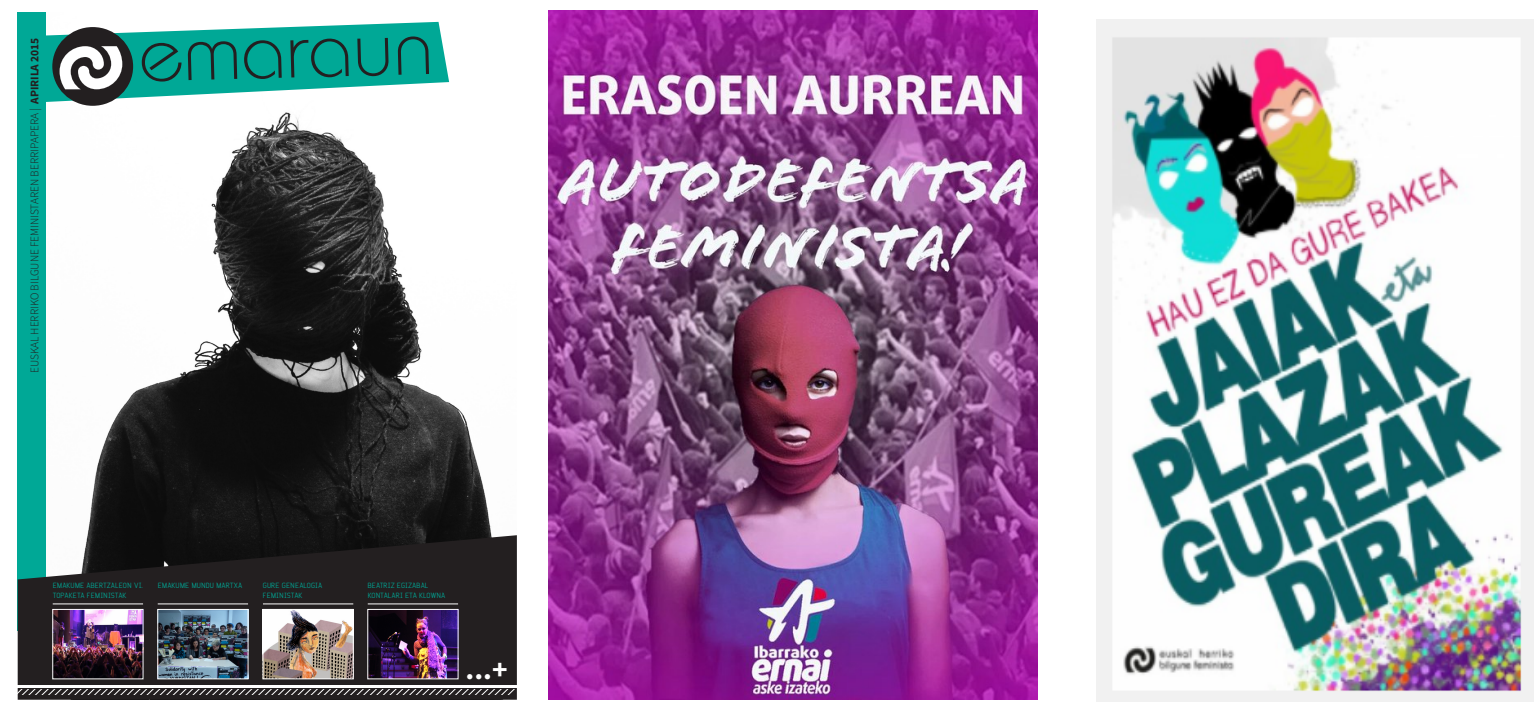

Fuentes diversas

De similar manera, el EHBF también ha integrado el pasamontañas como identificador de la lucha contra las violencias machistas, como gesto, diría, de legitimación de los esfuerzos conjuntos del MFV.

Esta incorporación de simbología del miedo y violencia de la que hablo se incorporó a nivel nacional y organizacional del EHBF en junio de 2016 (unos meses después de la movilización "Feministok Prest") cuando el EHBF publicó tanto en su página web oficial como a través de la revista online Argia, el manifiesto titulado 'FIESTAS POPULARES FEMINISTAS, 2016 Esta no es nuestra paz! Las fiestas y las plazas son nuestras!'. Aquella manifestación de 2014 en Iruña ha tenido un impacto a largo plazo en las estrategias elegidas del MFV en general, y el EHBF en particular. Esto queda reflejado en el manifiesto recién mencionado, al que pertenece el siguiente extracto la imagen 11:

"En fiestas, bajo la excusa del "todo vale", se agudiza la ofensiva de las

${ }^{69}$ La primera imagen desde la izquierda es la portada de la revista Emaraun, la revista mensual del EHBF de abril del 2015; la del medio es un poster de la línea feminista de Ernai que promueve la autodefensa feminista ante agresiones machistas y por último la foto de la derecha es el manifiesto "Esta no es nuestra paz" publicado por el EHBF en junio de 2016. 
agresiones sexistas: miradas, insultos, desprecios, violaciones, asesinatos... Por eso decimos que esta no es nuestra paz $^{70}$. Para muestra el montón de denuncias públicas de agresiones que ocurrieron en espacios festivos el verano pasado. Gracias al trabajo que ha realizado el movimiento feminista durante años estamos consiguiendo que la sociedad se conciencie ante estas agresiones; cada vez más barrios y pueblos elaboran sus protocolos; al fin y al cabo, cada vez más gente siente como suya la responsabilidad. Aunque la mayoría de la sociedad esté en contra de las agresiones, todo el mundo apoya a la víctima hasta que ésta decide responder. Si las mujeres osamos salir del papel de víctima pasiva y nos defendemos a nosotras mismas, aún hoy tenemos que escuchar que somos "unas calentadas", locas, histéricas o feminazis. Si respondemos, se nos pone en duda. Frente a este intento de deslegitimar a las mujeres rebeldes y el movimiento feminista, nosotras continuaremos con la autodefensa feminista" (Bilgune Feminista, 2016).

Interpreto que el icono del pasamontañas puede haberse convertido en una metonimia de las políticas feministas que guían el empleo de técnicas performativas de la violencia desarrolladas por el MFV, y que este estracto del manifiesto del EHBF que se presenta junto al póster de la imagen 11 lo refleja nítidamente. La cita engloba todos los elementos ideólogicos y de análisis que ha llevado al MFV a proponer la violencia performativa como herramienta de acción política: la concepción de agresiones sexistas que traspasa la concepción limitada a las relaciones de pareja heterosexuales, el problema de las agresiones crónicas en las macrofiestas populares, la activa presencia del movimiento feminista y la resistencia a que las mujeres tomen un rol activo ante las agresiones machistas.

En resumen, en este apartado he intentado argumentar cómo el MFV, a raíz de una experiencia particular, se ha sentido de acuerdo y así está fortaleciendo una estética combativa tanto discursiva como performativa y simbólica en sus manifestaciones que tienen como objetivo dar respuesta y promover la autodefensa feminista. Además, sugiero que la incorporación del pasamontañas como icono de esta lucha se puede considerar como legitimación del uso de representaciones que hacen uso de violencia performativa, así como generar una continuidad dentro del MFV.

\footnotetext{
${ }^{70}$ Pienso que la referencia a "esta no es nuestra paz", puede tener dos lecturas. Primero, como señala Jule Goikoetxea (2015), se refiere al discurso dominante que busca la paz del denominado 'conflicto vasco', es decir, la paz entre hombres cis blancos y heterosexuales, e ignorando todos los demás conflictos estructurales, como el racismo o machismo. Sin embargo, también entiendo que en el contexto particular en al que el manifiesto del EHBF está dirigido, también puede hacer referencia a la "paz establecida entre hombres en entornos festivos o lúdicos". Porque en cuanto un entorno es lúdico, se intenta evitar la alusión al conflicto, en este caso el conflicto de las violencias machistas.
} 


\subsection{Poder performativo y género}

Las técnicas performativas desempeñan un papel clave en la lucha del MFV en contra de las agresiones machistas porque las representaciones de estas manifestaciones o performances escenifican "nuestra capacidad, que somos capaces de responder y defendernos" (Hodei), y así, "iruditegiarekin jolastea zen helburua: biktimatik, gu ere antola gaitezke iruditegira ${ }^{71 "}$ (Hodei).

Como he tratado de exponer en el punto anterior, el miedo es la estrategia discursiva y política propuesta por las manifestaciones de "El Miedo Va a Cambiar de Bando". La agenciación del miedo se representa a través de lo que he estado denominando repetidamente como "técticas performativas de la violencia" o "violencia performativa", que aunque han sido planteados desde diferentes autores y contextos, considero que son compatibles. A pesar la continua mención a esto, aún no me he detenido a precisar cómo la definición que hace Medeak se puede poner en conversación con el marco teórico de Manzi, Rhodes, Butler y Spivak y Aretxaga.

Maialen hace referencia a estas manifestaciones como una forma de "ocupar ese espacio llamando la atención pero no generando agresiones, sino jugando con la violencia de forma performativa". Identifico aquí dos elementos que me parecen clave. Por una parte, el carácter performativo de esta modalidad de ocupar el espacio o de manifestarse, al que Betize hace referencia de la siguiente manera: "para mi esto es una mani pero no es una mani. Para mi esto es, sí, un teatro ${ }^{72 " ~(B e t i z e) . ~ P o r ~ o t r a ~ p a r t e, ~ a ~}$ través de ese teatro o performance, juegan con imaginarios de violencia, con representaciones que traen a la mente nociones de agresividad o violencia tal y como el pasamontañas, eslóganes directos, vestimenta negra y en ocasiones fuego y batukadas.

Sin embargo, tal y como señala Maialen, y como también subraya Medeak (2015), "no produce violencia, no hay golpes. Se autorganiza la seguridad, no hay policía, se evitan los altercados y la consigna es no enfrentarse". La definición o planteamiento de estas manifestaciones por parte de las activistas la considero compatible con la definición de 'símbolos de violencia o violencia performativa' que propone Manzi (2014): "forma de atuendo o vestimenta o comportamiento que evoca violencia sin necesariamente amenazar o resultar en violencia directa".

La definición de Manzi aplicada a "El Miedo Va a Cambiar de Bando" resulta interesante para poder exponer de forma descriptiva cómo podríamos definir, en rasgos generales,

\footnotetext{
71 "Jugar con el imaginario era el objetivo: de victima al imaginario de que nosotras también nos podemos organizar."

72 "niretzako hau da mani bat baina ez da mani bat. Niretzako hau da, bai, antzerki bat".
} 
la estrategia performativa de representar la apropiación del miedo y capacidad de agenciación del miedo y violencia como sujetas por parte del MFV. Considero esta una buena base para construir lecturas más profundas y concretas de cómo el empleo particular del MFV de la violencia posibilita crear un texto político y platea nuevos debates.

\subsubsection{Cuando mujeres ejercen violencia simbólica de noche: contradicción performativa \\ "Nunca hubiéramos imaginado que unas capuchas y unas cuantas antorchas en nuestras manos dieran más miedo que la violencia machista. Pero sabemos que no es miedo, es que nos hemos salido de las formas correctas que corresponden a las féminas" (Medeak, 2015).}

Utilizando las palabras de las activistas, a través del teatro, del juego con performances, se juega con imaginarios colectivos y se encarnan. Es decir, no sólo se dice a través de recursos discursivos tales como lemas que las mujeres tienen la capacidad de responder, y que además esa respuesta puede ser tan violenta como la agresión, sino que se pone en escena: un grupo de cuerpos escenifican la agenciación del miedo. ¿Cómo contribuye, qué aporta la encarnación (embodiment) de la agresividad y miedo como estrategia?

Por una parte, crea o produce una representación combativa y esta representación de la mujer constituye una "contradicción performativa" (Spivak y Butler, 2007: 63), en oposición tanto al imaginario de la mujer como pacifista o mujer como víctima. Por otra parte, estas manifestaciones exponen la performatividad de la identidad del género de manera similar a las prácticas del Drag, donde el carácter natural del género es deliberadamente parodiado.

Hacer una representación que expone que "el cuerpo definido como esencialmente débil puede ser fuerte o violento" (Medeak, 2015), interpreto que se puede entender como una contradicción performativa ya que las trans y mujeres que participan en estas manifestaciones performan, escenifican, encarnan y ocupan el espacio de la forma que precisamente las normas de género les prohíbe. Entonces, la concepción del constructo 'mujer' irreconciliable con creadora de violencia es uno de los elementos que constituye esta contradicción.

No obstante, no sólo esto, sino que también el lugar y momento en el que esta representación se escenifica contribuyen a la contradicción performativa: la noche. Ejercen a través de sus cuerpos una estética y actitud combativa, de confrontación, y además, esto lo hacen de negro, con la cara tapada y en las calles oscuras, en la noche, espacio y momento que está lleno de simbolismo:

"Gaua da emakumeei betidanik debekaturiko espazioa, gauak dira gauza txarrak gertatzen diren, imaginario honetan, gertatzen diren momentu hori. Etxera 
bakarrik bueltatzen zarenean, gaizkileak kalean dauden momentuetan. Baina baita parranda gertatzen den momentua, es que gaua sinbologiaz beteta dago ${ }^{73}$ " (Betize).

Las manifestaciones nocturnas y representaciones creadas en éstas "combinan el acto y lugar de significados simbólicos, culturales y políticos que espacios particulares representan" (Raento, 1996: 198), siendo en este caso el espacio particular la noche de fiesta donde las agresiones sexistas se llevan a cabo.

La motivación para esto es la necesidad de "poner en escena otros significados" (Medeak, 2015). Pero no sólo esto, Iraultza señala que los talleres de autodefensa, saber que tienes la capacidad de responder ante una agresión, no es suficiente para llevar esto a la práctica, ya que en general no tenemos acceso a la violencia en la misma medida en la que los hombres tienen a través de performar la masculinidad. Es por ello que la participación en estas manifestaciones, escenificar las técnicas de violencia performativa, nos sirve a las participantes para experimentar en nuestros cuerpos tal vez por primera vez "la capacidad, no es el uso, sino decir, me pongo todo esto y soy capaz" (Iraultza).

Es aquí donde les preguntaba a las activistas cómo o porqué la estética de la encapuchada es apropiada en cuanto a llevar a cabo la violencia performativa. Todas primeramente, subrayaban la sensación de grupo, de que no estar sola. Pero además, también apuntaban que la estética permite meterte en un personaje que no eres tu, como de forma bastante ilustrativa explica Iraultza:

"Una máscara siempre ayuda, a sacar y creerte fuerte. Creer diferentes tus fuerzas. Como si fueras una súper heroína ¿no? Pues si te pones el traje, crees más en tí misma, más que en Iraultza por la calle que igual en grupo tapada, $y$ con una estética que te ayuda a sacar esta mala hostia”.

Además, remarcaría que la sensación de anonimato que también mencionaron todas las activistas de alguna manera, no es tanto un anonimato por cobardía porque no ser conocida y tener libre albedrio para actuar sin consecuencias, sino una forma de desapegar por unos momentos el género y sus mandatos de tu cuerpo. Betize hace referencia a la función del pasamontañas de la siguiente manera:

"Buru berokiak erreferentizaltasun eza bermatzen du. Buru berokiak

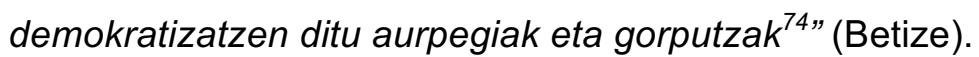

Es decir, entiendo la "falta de referencialidad" o la anonimidad como una forma de erradicar o liberar el género de nuestra performance temporalmente. Taparte la cara,

\footnotetext{
73 "La noche es el espacio que siempre se les ha prohibido a las mujeres, son las noches donde ocurren las cosas malas, es este imaginario, es en este momento. Cuando volvemos solas a casa, cuando los malhechores están en las calles. Pero también el momento en el que ocurre la fiesta, es que la noche está llena de simbología".

74 "El pasamontañas garantiza la falta de referencialidad. El pasamontañas democratiza las caras y los cuerpos".
} 
dejar de ser un cuerpo generizado, te posibilita convertirte en un cuerpo no marcado, por lo tanto, te abre la puerta de nuevas posibilidades de actuación.

El elemento performativo de estas manifestaciones deja en evidencia, como también interpreta Medeak, que el acceso a la violencia es performativo, pero que pertenece a la performatividad de la masculinidad. Por lo tanto, demuestra que "nos expropian la capacidad violenta de respuesta y fuerza a las tías" (Iraultza).

Es decir, las técnicas performativas de la violencia empleadas por el MFV no sólo crea contradicción performativa en cuanto al género, sino que también parodia la performatividad del género. Halberstam, al hablar de la masculinidad hegemónica, indica que "la excesiva masculinidad se convierte en una parodia o exposición de la norma" (Halberstam, 1998: 4). Es decir, una expresión exagerada de la masculinidad pone de manifiesto su performatividad, su carácter performativo, que tiene como objetivo repetir el ideal o la norma. Esta idea es lo que Butler (1990) argumenta en su teoría de la performatividad y el carácter subversivo de las performances de los Drag King y Drag Queen: cuestionan la expresión de género como expresión de un "yo o verdad interior", ponen de manifiesto la no- naturalidad de las identidades de género, y propone hablar de performatividades de género en lugar de expresiones de género como manifestación de algo interior y esencial (Butler, 1990).

De forma similar, en las manifestaciones nocturnas, a través de los pasamontañas que tapan la cara, tapan el género, se liberan las normas de conducta de género, por lo tanto, somos libres de performar conductas que de normal te son prohibidas, como la violencia contra las agresiones sexistas. ¿Qué produce esto? Desnaturaliza cuerpos leídos como mujer y sus capacidades. Subvierte el imaginario de las mujeres como recibidoras de miedo y agresiones, y no sujetas generadores de ello.

\subsubsection{Ocupación y Re- Significación Feminista del Espacio}

Quiero darle una vuelta más a la interpretación de las manifestaciones como contradicción performativa en cuanto al uso que hacen las manifestantes del espacio, y el significado simbólico que tiene cierto espacio y el uso dominante de éste. He sugerido anteriormente que parte de la contradicción performativa de estas manifestaciones yace en que las mujeres ocupen espacios que en el imaginario colectivo no pertenece a las mujeres. $Y$ de forma más concreta, cuando nos referimos a agresiones machistas, muchas veces se responsabiliza a las personas agredidas por estar en un sitio y momento en el que se normaliza que se realicen agresiones.

En la manifestación nacional de 2015 Feminsitok Prest, Farrukas y Oihuka organizaron un pasacalles llamado "Encarna tu Enfado" (Gorpuztu zure amorrua). En este pasacalles emplearon violencia performativa con el objetivo de trabajar el eje de la noche y la autodefensa. Maialen, que es de Gasteiz, compartió conmigo un análisis de este 
pasacalles que se realizó en un espacio y momento con gran carga simbólica cultural en Gasteiz, en especial para las mujeres:

"yo la lectura que hago aparte de a nivel nacional, también tiene una relación con la realidad local: aquí en fiestas se hacen los llamados "paseíllos" que son paseos donde los hombres van bailando, los blusas van bailando, mientras el resto de la gente, desde los aledaños, les mira.

Entonces, también era para mi un pasearnos por las calles donde se pasean ellos por fiestas sin ningún tipo de problema. Pues era también una forma de performar ¿no? Es decir, muchas mujeres de Gasteiz evitamos determinadas calles cuando pasan, cuando es el paseíllo, a pesar de que es durante el día, no tiene nada que ver con la noche, porque ese paseillo, pasar por ahí cerca significa que te puedan tocar, que te puedan decir, que te puedan pegar una pegatina, que demás... entonces, ocupar ese espacio llamando la atención pero no generando agresiones, sino jugando con la violencia de forma performativa nos parecía que era muy interesante".

El pasacalles en el que mujeres encapuchadas y de negro gritaban eslóganes como "machistas, cabrones, a los tiburones", o "polla violadora a la licuadora" ocupaba esas calles que en situaciones ordinarias están cargadas de miedo ante la posibilidad de ser agredida. Las violencias machistas están tan normalizadas, que en lugar de penalizar a los agresores, nuestra estrategia internalizada, como dice Maialen, es evitar ciertos espacios y momentos en los que la posibilidad y normalización de ser agredidas es aún mayor.

Por lo tanto, es poderosamente subversivo re- significar las calles en las que en circunstancias normales tenemos que estar alerta, a través de la creación de un espacio feminista y seguro. Esta re- significación, de forma similar a la agenciación de técnicas performativas violentas, tiene implicaciones dobles. Por una parte, muestra que el espacio público, las calles, no son de por sí peligrosas, que las agresiones no son inherentes al espacio público y la noche, al espacio que no nos corresponde. Es decir, desnaturaliza el peligro de las agresiones y peligro. Por otra parte, muestra una posibilidad de ocupar y utilizar el espacio nueva, una que deja en evidencia la normalización de las violencias en espacios públicos, y en este caso festivos.

De un modo similar, creo que esta interpretación de cómo las manifestaciones feministas re- significan las calles de Gasteiz donde se celebran los paseíllos de los blusas puede aplicarse a las manifestaciones nocturnas que se llevan en Bilbo a través de las Comparsas de Bilbao. La Semana Grande de Bilbao, como indica Betize, son unas "macro- fiestas". Parecido al caso de Gasteiz o Sanfermines, el aglutinamiento de gente y el alcohol sirven de excusa para el desfase y abuso (masculinista), por lo que 
se crea un ambiente en el que las agresiones machistas también tienden a normalizarse. Por ello, como dice Betize: "ez da berdina mani bat egitea, Arenaletik permisoarekin; eta beste gauza bat da, Bilboko jaietan, zapatu batetan, txosna- gunetik, baimenik gabe, mani bat egitea. Oso ezberdina $d a^{75 " \text { " }}$

Aplicando la lógica del análisis de Maialen, para mí la diferencia a la que se refiere Betize cuando dice "no es lo mismo hacer la manifestación en el Arenal o en la zona de txoznas", es que a diferencia del Arenal, la zona de txoznas, es un espacio que no tiene una carga simbólica en cuanto a las agresiones machistas especialmente relevante. Porque al igual que en el caso que menciona Maialen del paseíllo de los Blusas, el espacio de las txoznas es un espacio en el que está inscrito, normalizado, un uso del espacio en el que los hombres campan a sus anchas, ejerciendo todo su privilegio masculino.

Para remarcar la importancia de manifestarse en el txoznagune y durante uno de los días potentes de las fiestas, Betize señala que: "guri iaz gaztetxo pilok esan ziguten: bua! ¡Qué guapo, qué adrenalina! Pasar ahí por el medio, que los tíos te miren como tal, no se qué, tu ahí con el palo"'.

Esto me lleva a pensar que la re- significación del espacio, además, también se puede relacionar a que mientras ocurre la manifestación, se cambia el sujeto que acapara protagonismo, y además, de una forma transgresiva. Son las manifestantes las que ocupan el espacio central por unos momentos. Además, lo hacen desde un rol que se apropia de violencia performativa, haciendo pública la contradicción performativa.

Por último, añadiría algo más al caso de las acciones directas o manifestaciones que se llevan a cabo durante y lugar exacto de la celebración. Todas las activistas con las que estuve en contacto señalan que realizar acciones directas o manifestaciones que se llevan a cabo durante la celebración, in situ, es una exposición a la reacción de las personas que se encuentran en el lugar.

\subsection{Violencia Performativa: Incomodidad Multidireccional}

"Para mí el feminismo tiene que molestar, si no molesta, algo estamos haciendo mal" (Betize).

"Personalmente yo como feminista radical creo que si no somos incómodas pues estamos haciendo algo mal" (Maialen).

"Deserosotasuna sortzen badu, baliogarria izango da mailaren batean ${ }^{76 "}$ (Hodei).

\footnotetext{
${ }^{75}$ No es lo mismo hacer una mani, por el Arenal con permiso; y otra cosa es, en fiestas de Bilbao, un sábado, por la zona de txoznas, sin permiso, hacer una mani. Es muy diferente.

76 "Si crea incomodidad, entonces será útil/ valioso de alguna manera".
} 
Tanto la estética y performance, como la apelación directa de los eslóganes, como la ocupación y re- significación del espacio crean incomodidad, y esto lo conciben las activistas entrevistadas necesario para poder generar movimiento, cambio, transformación. Sin embargo, creo que el análisis de estas manifestaciones nos da cabida para analizar las múltiples maneras en las que crean incomodidad o molestias. Identifico tres formas, al menos en las que estas manifestaciones crean incomodidad o molestia, ya que el flujo entre acción política, activistas y sociedad no es unidireccional. Primeramente, debido a la exposición que conlleva la acción directa, las activistas se ven obligadas a hacer frente a situaciones difíciles, las cuales crean una posición incómoda, en cuanto a que en ocasiones se arriesgan personal y/o físicamente. En segundo lugar, muy interesantemente, esta propuesta performativa también causa incomodidad entre mujeres que no se sienten a gusto con esta estrategia política que emplea técnicas y estética de violencia performativa. $Y$ en tercer lugar, las manifestaciones identifican y así reparten la responsabilidad de las agresiones a los autores, lo que remueve y provoca muchas reacciones a la defensiva.

Por continuar con la idea con la que he finalizado el apartado previo, llevar a cabo acción directa conlleva poder recibir feedback o respuesta. Betize y Maialen cuentan experiencias de altercados al llevar a cabo acción directa, y ambas señalan lo duro que esto a veces puede resultar, especialmente, cuando se crea enfrentamiento con otra mujer:

"dentro de las cuadrillas de los blusas hay una cuadrilla que no acepta, bueno ellos dicen que sí, pero que no tiene mujeres a nivel práctico, en sus filas, digamos. Entonces lo que se hizo fue entrar en medio del paseillo encapuchadas con unas papelinas, unas pancartas y demás. Entonces ahí surgió una batalla campal, horrible, entre blusas y nosotras. El día siguiente suspendieron el paseíllo, salieron con una pancarta, que para mí fue especialmente dolorosa, porque fue una pancarta que llevaban las mujeres de las cuadrillas de blusas, en las que ponían: "no nos sentimos defendidas, nos sentimos ofendidas". Y para mí es especialmente duro" (Maialen).

"izan genituen bizpahiru mobida heavy. Eta tipa batekin, hori oso desatsegina izan zen. Dauz emakumeak ere que les parecemos lo puto peor. "Tú no me representas". Es que no quiero representarte. Emakume batekin horrela jartzea oso desatsegina iruditzen zait ${ }^{77 "}$ (Betize).

${ }^{77}$ Tuvimos un par o tres de movidas heavies. Y con una tipa, eso fe muy desagradable. También hay mujeres a las que les parecemos lo puro peor. "Tú no me representas". Es que no quiero representarte. Ponerse así con una mujer me parece muy desagradable". 
Aunque en otros fragmentos de las entrevistas también mencionan el riesgo a recibir golpes físicos, ya que, como indica Maialen, "a los hombres les han enseñado a agredir", ambas señalan lo doloroso que resulta tener que enfrentarse a otras mujeres. Las activistas del MFV están situándose deliberadamente en una situación de incomodidad, ya que son conscientes de que están rompiendo la norma, de que están ejecutando una contradicción performativa. En otras palabras, las activistas se exponen, personal y físicamente, con objetivos políticos, a la incomodidad.

Tal y como se puede entrever en las anteriores narrativas, las manifestaciones nocturnas tampoco son muy populares entre muchas mujeres, incluso entre mujeres que militan en el feminismo. Betize apunta que "politikoki aktibo diren emakume oso interesgarri kañera askorekin, gazteak, beste agian beste eragile batzutan ibiltzen direnak, bai egia da erresistentzia hori nabaritu dugula ${ }^{78, "}$. Esta resistencia yo la relaciono a la critica por el empleo de las herramientas del "amo", que entre otros, viene de sectores feministas como indica Betize, pero que no se alinean con esta estrategia. Abordaré esto en el punto 6.2.

Además, Maialen también identifica, y ella lo relaciona a lo internalizado que tenemos la posición en relación al miedo: "es cierto que a algunas mujeres no les resulta agradable. Pero bueno yo creo que eso es algo también que hay que tener ahí, tenemos que pensar, y que tiene que ver precisamente con todo ese miedo, con que nos han socializado en él". La socialización o educación generizada la relaciono con lo dicho anteriormente de la expropiación a las mujeres al acceso a la violencia, incluso si coge forma simbólica.

Por último, tal y como indica Hodei, estas manifestaciones tienen el poder de incomodar a las personas agresoras, a las creadoras de conflicto, y no solamente dejar en evidencia a la persona que visibiliza una agresión en un momento dado:

"gatazka bisibilizatzeak beti gu deseroso sentiarazten gaitu. Mani hauen botartez aukera handiagoa daukagu deserosotasuna gugandik irtetzeko. Bestea deseroso sentitu arte ez baita ezer mugituko ${ }^{79,}$

Tal y como refleja la primera parte de la cita, otro de los potenciales de las manifestaciones "el miedo va a cambiar de bando" es la capacidad de primero, sentirnos en grupo y solidaridad en la incomodidad de llamar la atención a los conflictos. Esto produce la solidaridad que Sarah Ahmed subraya entre las feministas, entre las feminist

78 Hemos notado esa resistencia de mujeres muy interesantes y cañeras que son políticamente activas, jóvenes, que a lo mejor andan en otros colectivos.

${ }^{79}$ Visibilizar el conflicto siempre nos hace sentir incómodas. A través de estas manis tenemos más opción de sacar esa incomodidad de nosotras. Porque hasta que el otro no se sienta incómodo no se va a cambiar nada. 
killjoy, las aguafiestas, las cuales son señaladas o acusadas por crear debate o discusión.

Segundo, ponen en evidencia la necesidad de que sean aquellas personas agresoras, y aquellas cómplices en el mantenimiento de la cultura de la violación, las que tienen que sentirse incómodas, ya que invierten la responsabilidad ante las agresiones: “¿Cuándo se van a responsabilizar los hombres? ¿Cuándo los agresores? ¿Cuándo la sociedad en su conjunto? ¿Cuándo van a empezar los socializados hombres a cuestionar su masculinidad y a deponer sus privilegios?" (Farrukas, 2016).

Uno de los elementos que hace posible incomodar o remover a la responsabilidad de los hombres y cómplices es el lenguaje directo de los eslóganes es otro de los elementos clave que incomoda.

"A los tíos lo que les pasa es que no están acostumbrados a que les digan directamente lo que son potencialmente o que ejercen sus privilegios. Entonces, claro, son los señoritos de nuestras sociedades" (Iraultza).

Los eslóganes como "matxirulo pin, pan, pun", "polla violadora a la licuadora" o "babosos al río" apelan directamente a los privilegios masculinos. Identifican la responsabilidad de los sujetos en las agresiones sexistas en vez de seguir tratándolo en abstracto. Evitan lo que Virgini Despentes denuncia que ocurre en referencia al silencio en torno a las violaciones:

"Mientras no lleva su nombre [en este caso que las agresiones tienen autores] la agresión pierde su especificidad, puede confundirse con otras agresiones, como que te roben "(2007: 34$)$.

Las posturas defensivas ante apelaciones son muestra de la hipocresía de aquellas personas con posturas políticamente correctas en torno a las agresiones sexistas, ya que no asumir responsabilidades y atacar al Movimiento Feminista porque estas no son las formas solo verifica la falta de voluntad de renunciar a sus privilegios, o de "bajarse del pódium de los privilegios" como dice Betize. Farrukas se dirige así a aquellas personas que se sientan incomodadas ante la alusión tanto de los eslóganes como de la estrategia en general: "Y, sí, amigos, la pérdida de poder y privilegios da miedo, y he aquí, el aporte pedagógico de la frase [El Miedo Va a Cambiar de Bando]." 


\section{SITUANDO LA VIOLENCIA PERFORMATIVA EN EUSKAL HERRIA: NACIONALISMO, GÉNERO Y LAS TÉCNICAS PERFORMATIVAS DE LA VIOLENCIA DEL MFV}

Conforme a Butler (1990), el género es la manifestación del significado que el sexo es asignado en un contexto cultural determinado, mientras que el sexo también se manifiesta de acuerdo a una lógica similar a la historicidad construida, así irrumpiendo en las características inmutables atribuidas a ambas categorías. De esta manera, el análisis de las manifestaciones de "el miedo va a cambiar de bando" no pueden ser examinadas como si se dieran en un vacío. Con el objetivo de explorar el significado y significación de la violencia performativa que se da en las manifestaciones, me parece relevante situar la performance de la que los símbolos tienen resonancia en el imaginario cultural en Euskal Herria. Sugiero que estos símbolos recuerdan a la lucha armada del MLNV, y en este apartado propongo que la performance de las manifestaciones nocturnas constituye una contradicción performativa acentuada por el uso del pasamontañas que acarrea tras de él específicas connotaciones asociadas a los ideales generizados, y específicamente masculinistas, propios del MLNV.

En esta segunda parte analítica, por lo tanto, haré una lectura de las manifestaciones que emplean violencia performativa dentro del marco simbólicoritual del MLNV, con el objetivo de analizar cómo la intersección entre el imaginario del nacionalismo vasco radical, los discursos culturales de género y política influyen el imaginario y la percepción de las técnicas performativas de la violencia optadas por el MFV.
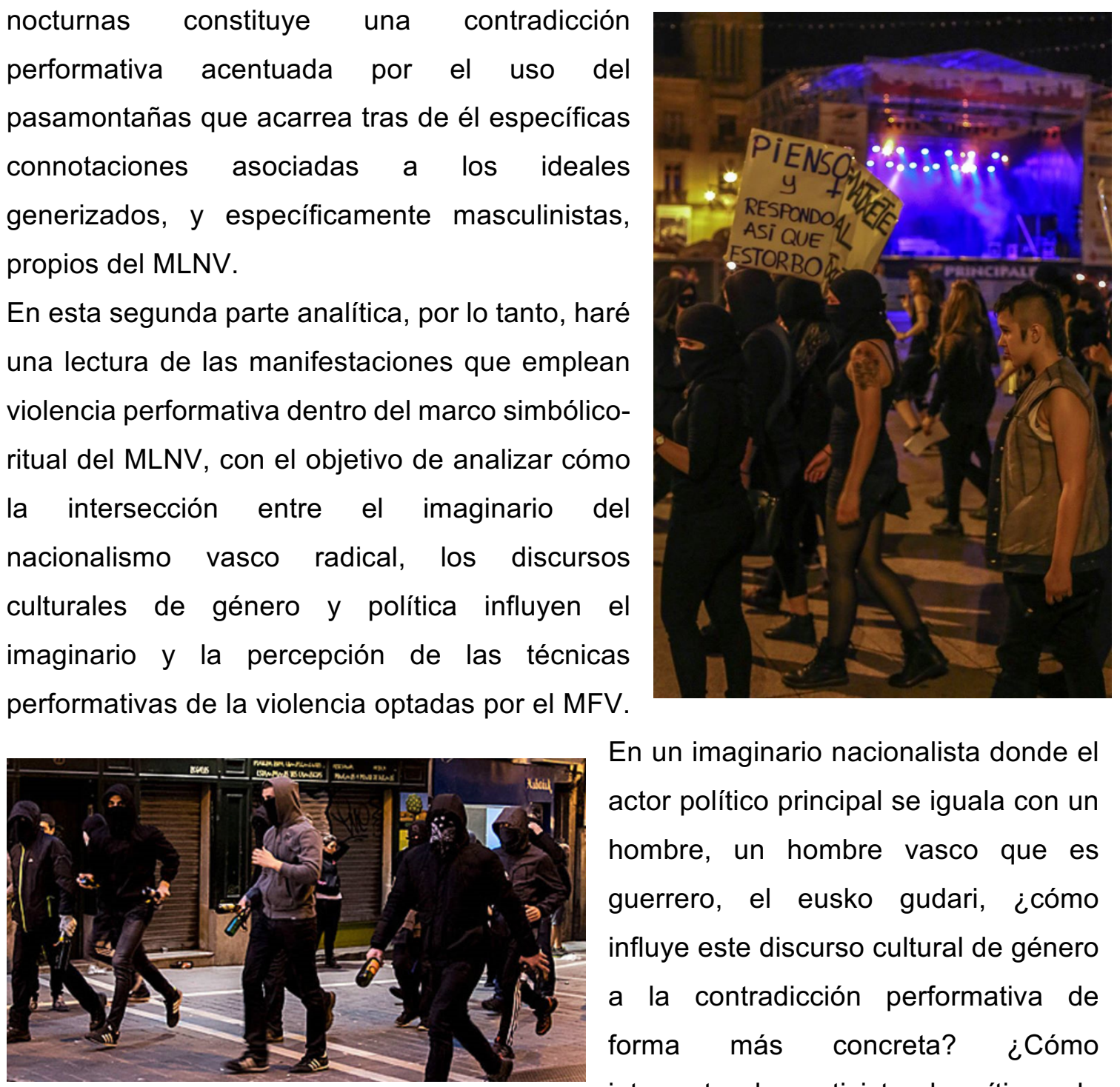

En un imaginario nacionalista donde el actor político principal se iguala con un hombre, un hombre vasco que es guerrero, el eusko gudari, ¿cómo influye este discurso cultural de género a la contradicción performativa de forma más concreta? ¿Cómo interpretan las activistas la crítica a la asimilación o el peligro de "reproducir la misma violencia que criticamos" (Medeak, 2014: 
78)? ¿Qué ocurre cuándo el MFV coge las calles, en ocasiones de noche, se apropia de símbolos que se relacionan al imaginario de la lucha armada y se reivindica así un conflicto que no es "el conflicto vasco"?

\subsection{La Eusko Gudari Femenina: una Contradicción Performativa de las Políticas de Género del MLNV}

Al preguntar sobre el símbolo del pasamontañas a las activistas, todas señalan que este elemento estético ha sido empleado numerosas veces y por diversos grupos internacionalmente, así como las zapatistas o las Pussy Riot. A pesar de esto, simultáneamente, también indican que entienden que en el contexto vasco el imaginario político colectivo relacione el pasamontañas a la lucha armada: "imaginario hori dago, borroka armatuarena. Kultura ezberdinetan... kontua da hemen esanahi ezberdina daukala 80 " (Betize).

De forma más precisa, el uso del pasamontañas alude al sujeto político de la lucha armada vasca, a lo que podemos denominar también como la figura cultural del eusko gudari:

"Ponerse una peluca es performar, lo que pasa que hay ciertas performatividades que resultan incomodas y que en estos contextos no se permite. No se permite porque no toca pero también porque no somos el sujeto que tiene derecho a hacer esa performance, porque cuando sí que tocaba, el imaginario colectivo del encapuchado obviamente no era el imaginario de una mujer. Y no solo el imaginario del encapuchado, nosotras siempre decimos, y a mi me gusta mucho como remarcar que lo que hace mucho daño no solo es la capucha sino la minifalda y las medias de rejilla que llevan esa capucha que dejan claro que debajo de esa capucha no hay un tío cis" (Maialen). Maialen enfatiza que el elemento que inquieta va más allá de hacer alusión a significados culturales propios del contexto socio- cultural e histórico vasco, que lo que realmente perturba es retar esos imaginarios determinadamente generizados, concretamente, masculinizados. En otras palabras, "en el fondo está que somos mujeres tapadas, porque quiero decir, existen Black Blocks, existen movimientos que se tapan la cara incluso en este contexto en Euskal Herria y no generan tanto esto" (Iraultza).

Esto deja de relieve lo arraigados y naturalizados que siguen estando los discursos de género escondidos tras los modelos culturales, como es en este caso el gudari. Así,

80 "Hay ese imaginario, el de la lucha armada... en culturas diferentes... la cosa es que aquí tiene un significado diferente" (Betize). 
considero que podemos interpretar esto como una instancia de que "todavía a día de hoy hacemos la identificación del 'hombre militante y la mujer cuidadora' " (Rodriguez Lara y Etxebarrieta Legrand, 2016: 31). Es decir, la ecuación entre el gudari, el militante, el sujeto político, y hombre, la cual es difícil de deshacer, ya que como indica Nagel (1998: 251-252): "the culture of nationalism is constructed to emphasize and resonate with masculine cultural themes. Terms like honour, patriotism, cowardice, bravery and duty are hard to distinguish as either nationalistic or masculinist, since they seem so thoroughly tied both to the nation and to manliness ${ }^{81 "}$.

Considero que esta ecuación puede entenderse como una forma de intensificar la contradicción performativa que he justificado en el capitulo anterior, al hacer la lectura situada dentro del imaginario y ritual del MLNV:

"Porque además, nosotras una de las reivindicaciones es, "no queremos ser valientes queremos ser libres". Y el gudari siempre es valiente ¿no?, entonces también rompes con cierta dinámica" (Maialen).

Tal y como indica Maialen, la contradicción performativa surgida al escenificar no sólo crea performatividades de género no normativas al romper con las normas de género que despropian a las mujeres del uso de la violencia, sino que además, subvierten los valores masculinistas atribuidos al gudari, tal y como 'valentía'. Es decir, evocan a una figura cultural masculinizada, pero además de no ser las sujetas correspondientes, también cuestionan los valores que esa figura representa. Pone en contradicción aquellos temas culturales asociados al cuerpo masculino tales como el honor, valentía o deber (Nagel, 1998) que la militarización de la lucha política y cultural nacionalista ha construido.

\subsection{Debate feminista sobre imitación o apropiación de las "herramientas del amo"}

La última cita que hace alusión al potencial de la contradicción performativa como estrategia para generar algo nuevo (Butler y Spivak, 2007), sin embargo, ha sido en numerosas ocasiones tema de debate feminista cuando esa contradicción performativa emplea la apropiación o involucración en estrategias o métodos que son planteados originalmente desde políticas o posturas dominadas por hombres y que privilegian su posición. En esta línea, podemos hablar de dos aspectos: por una parte, de si las representaciones que traen a la memoria idearios nacionalistas de la lucha armada se

\footnotetext{
${ }^{81}$ La cultura del nacionalismo es construida para enfatizar y hacer resonancia con temas culturales masculinos. Términos como honor, patriotismo, cobardía, valentía y deber son difíciles de distinguir bien como nacionalista o masculinista, ya que ambos parecen completamente apegados tanto a la nación como a la hombría.
} 
pueden considerar una forma de reivindicar pertenencia o continuidad por el MFV con el MLNV. Por otra parte, quiero poner en debate la crítica que achaca al empleo de violencia performativa como forma de asimilación de estrategias políticas. Tales debates problematizan la idea de Audre Lord (1983: 94-101) que dice que "las herramientas del amo nunca desmantelarán la casa del amo". Mi foco en la violencia performativa y contradicción performativa en formas de manifestación sugiere que, de hecho, las herramientas del amo contienen potencial subversivo para desmantelar estructuras hegemónicas, dependiendo de aquellos cuerpos que emplean las herramientas y los objetivos con los que están siendo utilizadas.

En respuesta a la vinculación entre el símbolo del pasamontañas de las manifestaciones de "El Miedo Va a Cambiar de Bando" del MFV y el pasamontañas que evoca a la lucha armada del MLNV, como he expuesto al comienzo del capítulo cinco, las activistas explícitamente se posicionan, a nivel de grupo o colectivo, como autónomas. En oposición a la vinculación al MLNV, subrayan que el objetivo de haber escogido el pasamontañas es su poder de impersonalizar para así destacar que todas podemos recibir violencias sexistas indiscriminadamente (no sin ignorar intersecciones) por el hecho de ser mujer. Traigo aquí las palabras del grupo que propuso por primera vez esta estética:

"Nos ponemos la capucha porque crea una identidad colectiva como estrategia de lucha contra la individualización y el control heteropatriarcal. Cualquiera puede ser agredida, podemos ser todas. ¡Si tocan a una respondemos todas!" (Farrukas, 2016).

Al reivindicar que no es un problema individual, hacen evidente la naturaleza estructural y social de las agresiones, por lo que la respuesta será proporcional a la gravedad de estas. Así, aclaran también que:

"El objetivo de ir tapadas no es ocultarnos; no lo hacemos ni por miedo, ni por vergüenza. Muy al contrario, hemos tenido que encapucharnos para que se nos vea. La trascendencia y el impacto que ha tenido lo demuestran" (Farrucas, 2016).

El discurso que han desarrollado los colectivos que promueven de forma más elaborada la violencia performativa es firme y contundentemente argumentado. Aunque no sugeriría que la alusión de las técnicas performativas llevadas a cabo por las manifestaciones nocturnas al imaginario de la lucha armada constituyan una señal de pertenencia al MLNV, considero que parte de la "transcendencia y el impacto" de estas manifestaciones, parafraseando las palabras de Farrukas (2016), puede deberse, parcialmente, a la resonancia específica que el símbolo del pasamontañas tiene en el 
contexto vasco, y la exacerbada contradicción performativa que crea esta alusión. Aun así, no atribuyo en absoluto todo el peso de su éxito, en cuanto a suscitador de debate, al hecho de que evoca a imaginarios pertenecientes de forma particular a este contexto histórico, político y cultural vasco. No obstante, estas reflexiones invitan a reexaminar la eficacia de estrategias feministas al subrayar la importancia de historias culturales ya que están relacionadas a nacionalismo, género, y en este caso a problemas sociales como violencias sexistas.

La figura cultural a la que las representaciones que se crean en las manifestaciones que se apropian de violencia performativa evocan valores o estrategias políticas que se relacionan a lo masculino. Debido a esto, parte de las críticas que estas manifestaciones han recibido en cuanto a las técnicas performativas escogidas, son las siguientes:

"Itziar Zigak edo Monroyk egindako artikuluetan esaten zuten azkenean gu etsaia bezala ari ginela aktuatzen ${ }^{82 " ~(B e t i z e) . ~}$

A través de la palabra "enemigo", en el contexto de las violencias machistas, Betize hace referencia a los agresores, y de forma más abstracta, al sistema patriarcal, que como he dicho en el capítulo cinco, emplea el miedo y la violencia como estrategia para someter a las mujeres y ejercer violencia. La crítica a la incorporación de técnicas masculinistas en la acción feminista en un debate común, como indica Yuval Davis (1997) en muchos contextos de conflicto nacionalista. Entre otros, fue el caso del debate feminista del contexto irlandés durante el movimiento de liberación nacional. Los grupos feministas dominantes, encabezado por el Movimiento de los derechos de las Mujeres de Irlanda del Norte (NIWRM), criticaban a las mujeres que participaban en el movimiento republicano por imitar las estrategias de un movimiento dominado por hombres. De forma similar, la crítica de Monroy o feministas que no se alinean con la estrategia de la apropiación del miedo y violencia performativa es la de caer en asimilacionismo o imitación de estrategias políticas. Ante esto, Medeak responde lo siguiente:

"Esta cuestión [reapropiarse de técnicas performativas de la violencia] es polémica y compleja: no se trata de reproducir la misma violencia que criticamos, no se trata de convertirnos en <<los amos>>" (2014: 78).

En la misma línea, Iraultza indica que "no queremos hacer la misma mierda patriarcal: nuestro uso de la violencia parte desde la autodefensa, y parte también desde reorganizar y repartir equitativamente esa capacidad de dar miedo".

82 "En los artículos escritos por Itziar Ziga o Monroy lo que decían era que al final nosotras estábamos actuando como el enemigo" (Betize). 
El origen de la propuesta del empleo de la muestra de fuerza, es radicalmente diferente desde los grupos feministas que desde "el enemigo", el patriarcado. El objetivo del patriarcado es oprimir, someter; el de los colectivos feministas, en oposición, surge de la necesidad de crear nuevas estrategias de defenderse ante brutal y normalizadas violencias diarias.

Al hablar sobre el debate entre asimilación o trasgresión por parte de las parejas homosexuales que buscan imitar la pareja y familia heteronorma, Sarah Ahmed (2004) define la decisión de la asimilación de la siguiente manera:

"The choice of assimilation - queer skin, straight masks - is clearly about supporting the violence of heteronormative distinctions between legitimate and illegitimate lives ${ }^{83 "}$ (150).

Esta definición establece que una imitación debe tener como objetivo mantener el imperativo que dicta lo que es legítimo y lo que no. Basándonos en esta idea, la opción de las técnicas performativas de la violencia como estrategia política ante las agresiones machistas no tendrían por qué ser consideradas como una forma de imitación o asimilación ya que, como indican las activistas, el objetivo no es establecer distinciones entre formas legítimas e ilegítimas de responder ante violencias machistas. Más bien, pretenden desestabilizar las estructuras que permiten a los binarios tales como legitimo/ ilegitimo, débil/ fuerte, pasivo/ activo se reproduzcan constantemente, como indica Maialen:

"Creo que es positivo que haya ese debate, me refiero, el feminismo no es uno, entonces las estrategias son múltiples, y muchas veces contradictorias" (Maialen).

"Y luego te voy a decir, las manis se pide (propone) ir encapuchada, de negro lo que sea... pero si no vas no pasa nada. Hay maneras de participar. No es un requisito ¿no? No se pasa lista. Entonces las ultimas veces se ha ido ampliando también eso... yo qué se hay gente que ha venido con pelucas... pero por eso deja de ser un espacio manifestable ¿no? Entonces esto también es muy significativo de la lucha feminista ¿no? Que todas las luchas y formas de expresión son bienvenidas. Se vio en feministok prest" (Iraultza).

Es decir, esta propuesta performativa y estética lanzada por algunos sectores del MFV, son propuestas, no más que eso, y no tienen como objetivo establecer nuevas normas o imperativos que dicten la única estrategia legítima para responder ante las agresiones sexistas. Por ello, achacarles un intento de imitación creo que requiere un análisis

${ }^{83}$ La elección de la asimilación - piel cuir/queer, máscara heterosexual - se trata de apoyar la violencia de la distinción heteronormativa entre vidas legitimas o ilegítimas. 
complejo y argumentado.

Por último, mi objetivo no es caer en el discurso dicotómico de si estas manifestaciones son o no asimilacionistas de ciertos "imperativos performativos" del MLNV, sin embargo, considero enriquecedor proponer lecturas que diversifiquen los ejes de interpretación. Por ello, como contribución adicional ante el debate sobre la imitación, me parece interesante aplicar la teoría de la performatividad de Butler para ampliar esta reflexión.

Si aplicamos la idea de la teoría de la performatividad de Butler (1990) que sostiene que la repetición o imitación del ideal

nunca es exacta, neutra, es decir, Imagen 12: Pasamontañas Queer

que la performance es siempre nueva, podemos entender el poder de las técnicas performativas de las manifestaciones del MFV de dos modos. Por una parte, lo sugerido en el capitulo cinco sobre la creación de representaciones e imaginarios de feminidad nuevos y que dejan en evidencia el carácter performativo del acceso a la violencia. Por otra parte, en relación a la crítica de asimilar las estrategias del "amo", si aplicamos esta idea de que cada imitación es un fracaso en el intento de imitar ese ideal, estas performances, aunque hipotéticamente tuvieran el objetivo explicito de hacer referencia a la lucha armada, nunca lo reproducirían de forma exacta, puesto que no sería más que una versión nueva.

Asimismo, no solamente manifiestan tajantemente que el objetivo del uso simbólico de violencia no comparte los objetivos de las violencias machistas, sino que si hacemos una observación estética de aquellos símbolos que traen a la memoria símbolos culturales como el

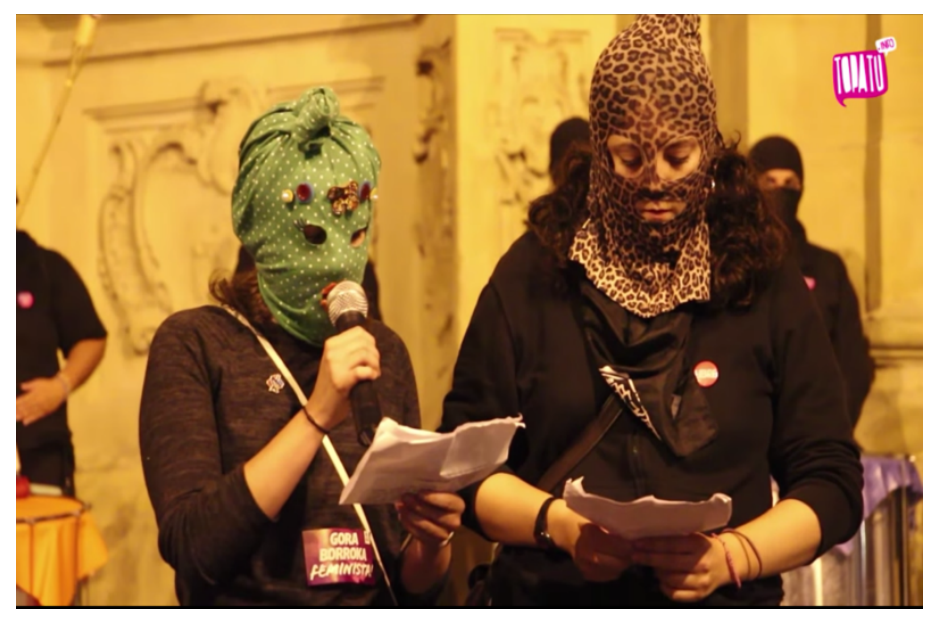
pasamontañas, en algunas de las manifestaciones las activistas han diseñado versiones de este símbolo. La reconversión o 'hacer queer (del verbo to queer en inglés) del símbolo del pasamontañas opino que se refleja bien en la imagen 12 que traigo. En esta, el clásico pasamontañas negro, se transforma a través de telas coloridas e incluso me atrevería a decir que a través de estampados, colores y adornos que podríamos clasificar como tradicionalmente femeninos: labios rojos y las flores en la frente en el caso del pasamontañas verde, el estampado de leopardo 'sexy'. Propongo que este 
queering del pasamontañas lo podríamos interpretar como una deliberada manifestación de no tener intención de imitar un símbolo cultural concreto. Esto me recuerda a lo que Jokiz Azpiazu Carballo recuerda al hilo de la historia de la reapropiación feminista:

"Audre Lorde (2007) nos recuerda el precio a pagar por re- apropiar (algunas de) las herramientas del amo, afirmando que las dinámicas propias del patriarcado son tremendamente poderosas. Para no caer en sus trampas, propone el uso de las diferencias como fuerza creativa. Se establece, de esta manera, una tensión constante y continuada entre la re-apropiación y la potencia creativa" (Azpiazu Carballo, 2014: 114).

Lo que la imagen recién mostrada y esta cita me sugieren, es que la propuesta del MFV de reapropiarse las técnicas performativas de la violencia podrían entenderse como un ilustrativo caso de la aplicación de la fuerza creativa. De modo que mantiene lo que Azpiazu Carballo ha sugerido de mantener la "tensión constante y continuada entre la re-apropiación y la potencia creativa" (2014: 114).

\subsection{El poder de las técnicas performativas de la violencia y re- apropiación símbolos y discursos culturales: sacar a la luz debates en los márgenes}

"Cuando tú te calzas una capucha, utilizas el fuego como elemento de acción política, la noche, y además utilizas ciertos lemas históricos y los reconviertes ¿no?, pues "bollera da bide bakarra" (bollera es la única opción) [en lugar de borroka da bide bakarra (la lucha es la única opción)], o algunas de estas, generan cierta bueno, no dejan indiferente y generan cierta contradicción en un espacio ideológico que habla de paz, en este momento" (Maialen). Este análisis que compartió Maialen conmigo, junto con la crítica que el feminismo vasco le ha hecho al denominado proceso de paz que ignora la necesidad de abordar la construcción de la paz de forma holística y contemplando los diversos conflictos estructurales que quedan ignorados bajo el discurso dominante de el "conflicto (independentista) vasco", propongo aquí otra lectura que nos posibilita hacer el empleo de técnicas performativas.

En este apartado sugiero que las técnicas performativas que emplea el MFV ante las agresiones machistas, debido al uso de símbolos culturales, tiene la capacidad de sacar a la luz y fomentar debate sobre conflictos que en el discurso político dominante quedan en los márgenes. Es decir, además del potencial político que he desarrollado en el capitulo cinco, más directamente ligado al conflicto de las violencias sexistas desde donde surge la propuesta, propongo que a través de representaciones que retan los 
imaginarios colectivos de género y culturales e históricos nacionalistas, permiten hacer un análisis más allá de los objetivos directos de las manifestaciones y abrir temas de debate no- dominantes. En otras palabras, tal y como indican Manzi (2014) y Watson (1996), sugiero que algunos de los efectos que produce un acto político que hace uso de violencia performativa puede que queden fuera de los objetivos inicialmente planteados. Parte de este efecto se debe al contexto histórico y cultural del entorno en el que esto ocurra y yo le añadiría a esta idea el elemento del género o los discursos culturales de género del contexto particular.

Tal y como dice Maialen en la cita anterior y también lo señala Rodriguez Lara (2015), la apropiación y reconversión de la estética elegida y lemas con resonancia histórica tal como "Borroka da Bide Bakarra" abren el debate sobre la lectura feminista de lo que llamamos 'el conflicto vasco' en singular. El origen de "no dejar indiferente y generar contradicción en el discurso político actual" lo localiza en el uso de los símbolos que tienen una lectura cultural particular en Euskal Herria.

"Beldurra dago, buru berokia sinbolo potentea da Euskal Herrian: beldurra, terrorismoaren, biolentziaren ikurra da, eta beste emakume talde batekoek hori janztea berriro, ez ba nik ulertzen dut gustoko ez izatea ${ }^{84 "}$ (Betize).

Debido al significado particular que adquiere el símbolo del pasamontañas, relacionado a temas como el terrorismo y la violencia, pasado que como indica Esteban (2016) no ha sido aún digerida en Euskal Herria. Estas manifestaciones, entre otros muchos efectos que he ido mencionando, tienen el poder del uso de símbolos concretos con significados culturales e históricos, y son así símbolos encadenantes de reacción y mensaje político.

En el caso de las manifestaciones del MFV, son los pasamontañas, el fuego y la vestimenta negra los que pueden ser interpretados como recordatorios culturales e históricos. No obstante, son empleados, como el ejemplo del pasamontañas de leopardo y verde que he traído en la imagen $\mathrm{J}$ y el lema que menciona Maialen de Bollera da Bide Bakarra, de forma que resignifican su sentido convencional y original. De acuerdo a Spike Peterson (2013: 58), "feminist/queer movements challenge the 'givens' of heteropatriarchy ${ }^{85 "}$ y son estos movimientos los que "offer not only the most telling and informed critique of heteronormativity and its political effects, but also, potentially, the

\footnotetext{
84 "Hay miedo, el pasamontañas es un símbolo potente en Euskal Herria: es el signo del miedo, terrorismo, violencia, y que mujeres lo utilicen otra vez, pues entiendo que no les guste".

85 Los movimientos feministas/ queer retan 'lo que se da por hecho' en el heteropatriarcado (Spike Peterson, 2013: 58).
} 
most transformative analysis of power inequalities - across individual, interpersonal, group, national, and global levels ${ }^{86 "}$ (2013: 58).

Originalmente, los elementos que indica Maialen simboliza la lucha independentista vasca, por lo que la simbología elegida en esta protesta nos hace recordar la historicidad. Sin embargo, de forma paralela a cuando las prisioneras de IRA en Irlanda del Norte se unieron a la Dirty Protest en 1980, resignifican el significado convencional. ¿Cómo lo hacen en el caso del MFV? Primeramente, puesto que, a diferencia del caso irlandés, el empleo del símbolo del pasamontañas surge con objetivos políticos completamente diferentes al pasamontañas que se empleaba durante los años del conflicto armado vasco. Segundamente, por la incorporación de otros símbolos tal y como medias de rejilla, que aluden al género, que cambian el significado a través de lo que he estado tratando como contradicción performativa, como apunta Maialen: "la minifalda y las medias de rejilla que llevan esa capucha que dejan claro que debajo de esa capucha no hay un tío cis", que indica la centralidad del sexo y género para conceptos como miedo, violencia y poder más generalmente.

En el capitulo dos, al presentar las características estéticas o performativas de las manifestaciones que tengo como objeto de estudio, he señalado parte del manifiesto que el Euskal Herriko Bilgune Feminista publicó en junio del 2016 uniéndose a la propuesta de Farrukas en cuanto a las técnicas performativas de la violencia y promoción de la acción directa. Traigo aquí un fragmento:

"En fiestas, bajo la excusa del "todo vale", se agudiza la ofensiva de las agresiones sexistas: miradas, insultos, desprecios, violaciones, asesinatos... Por eso decimos que esta no es nuestra paz" (Bilgune Feminista, 2016).

Al decir esta no es nuestra paz, es posible hacer dos lecturas. Por una parte, se puede interpretar como la crítica a la concepción de paz que entiende la paz como la situación en la que "los hombres encuentran un acuerdo" y que normaliza violencias, tales como las machistas o racistas (Goikoetxea, 2015). La fiesta puede representar una de estas interpretaciones de paz patriarcales y androcéntrica, en la cual sólo los hombres, y yo añadiría blancos y heterosexuales, disfrutan de libertad de agresiones por razones de discriminaciones estructurales.

Por otra parte, como he tratado de justificar en los párrafos anteriores, debido al empleo de símbolos que nos sitúan en una historicidad particular a través de su resonancia cultural e histórica, considero que la referencia a la paz también puede ser interpretada

${ }^{86}$ ofrecen no solo las críticas más significativas e informadas de la heteronormatividad y sus efectos políticos, pero también, potencialmente, el análisis más transgresivo de las desigualdades de poder - a nivel individual, interpresonal, grupal, nacional y global 
como la crítica feminista hecha al discurso heteronormativo y dominante sobre el conflicto vasco formulado en singular. De esta manera, esta interpretación a la crítica del discurso de paz del actual ciclo político vasco "pone en tela de juicio esos discursos del lema "bakea orain". Nosotras decimos que 'esa paz' tiene que llegar de una manera mucho mas integral y mucho mas estructural y que en este momento se sigue asesinando en Euskal Herria" (Maialen). De lo contrario, se reproduce el discurso patriarcal de concepciones de paz que normalizan violencias (Goikoetxea, 2015) el cual silencia los múltiples conflictos y los excluye del dialogo del proceso de paz. El peligro de ignorar una perspectiva integral, es reestablecer los sistemas de opresiones (Spivak, 2014; Yuval- Davis, 1997), tal y como se ha demostrado en naciones post- coloniales y naciones en proceso de descolonización. Por lo tanto, esto es un recordatorio de que debemos cuestionar constantemente los efectos totalizadores producidos a través de discursos de "paz", preguntándonos quién ha obtenido paz. Debemos ser conscientes del hecho de que la paz tiene siempre un coste, como tal, poner sobre la mesa quién paga el pato. 


\section{CONCLUSIONES}

A lo largo del presente trabajo he tratado de hacer un análisis en profundidad sobre las representaciones y performances del MFV que se agencian de violencia performativa o técnicas performativas de la violencia y sus postulados políticos. Esto me ha llevado a concluir que es la contradicción performativa la principal causa de las incomodidades e inquietudes. La contradicción performativa que se basa en proponer una representación de mujeres capaces de generar respuestas directas y violentas ante las violencias machistas, en oposición a las normas de género esencialistas que nos intenta definir como débiles, pasivas y siempre víctimas ante las agresiones, identifico los siguientes movilizadores de incomodidad.

Primeramente, el empleo de técnicas performativas de la violencia deja en evidencia el carácter performativo del género, por ende, el acceso que la masculinidad ofrece al ejercicio del miedo y la violencia. Esto, asimismo, revela cómo la idea de que el miedo es una cualidad inherente experimentada (pasivamente) por las mujeres y ejercida (activamente) por los hombres es un constructo naturalizado e interiorizado que una performatividades subversivas puede desmantelar. Así, la propuesta discursiva y performativa de estas manifestaciones posibilitan, por una parte, un discurso político que expone la forma en que el miedo y violencia son una herramienta para someter a las mujeres; por otro lado, que ésta se ejerce a través de performatividad aceptable para los hombres y expropiada a las mujeres. Además, una de las contribuciones que destacaría del empleo de técnicas performativas es que través de crear un espacio para performar durante las manifestaciones, para hacer teatro y convertirnos en cuerpos no sexuados a través de las máscaras, podemos, tal vez por primera vez para algunas de nosotras, llevar a cabo una violencia o agresividad simbólica. Y recordemos, que esto es en respuesta a agresiones sistémicas y no arbitrariamente o con el objetivo de oprimir, en contraste a la lógica patriarcal.

El empleo de símbolos tales como el pasamontañas en el contexto vasco tiene especial resonancia debido a la evocación a la estética de la lucha armada del MLNV. Sugiero que al añadir la lectura situada y contextual a la exploración de cómo el sistema de género subyace en el debate en torno al uso de técnicas performativas de la violencia como estrategia política feminista acentúa la contradicción performativa y tiene especial resonancia porque las performances "dependen de un contexto y una recepción que puedan provocar confusiones subversivas" (Butler, 1990: 271). Y sostengo que es el reforzamiento de la masculinización del sujeto político nacionalista a través de la intersección entre el nacionalismo y la militarización por la búsqueda de la independencia los que tienen el poder de crear tal potencial subversivo en las 
manifestaciones nocturnas dentro del contexto vasco. En otras palabras, la construcción cultural de identidades de género monocromáticas del MLNV exacerban la contradicción performativa de las representaciones de las manifestaciones nocturnas.

Por lo tanto, debido a la relevancia de las estructuras y normas culturales, sociales y políticas que se entretejen con o se forman sobre políticas de género, las técnicas performativas de estas manifestaciones contribuyen a retar los binarismos que reproducen y mantienen en el centro de la esfera política el sujeto político masculinizado y androcéntrico. Dicho de otra forma, puede considerarse como un ejemplo de lo que afirman Butler y Spivak sobre que "no puede haber políticas radicales de cambio sin contradicción performativa, ya que si esta contradicción se trabaja y expone, puede llevar a algo nuevo" (2007: 64).

Por último, subrayaría dos potenciales políticos que ofrece el empleo de técnicas performativas. Primero, al agenciarse de una performance que representa a las mujeres no como pasivas receptoras del miedo y violencia, sino como sujetas activas, legítimas y capaces de defenderse y responder ante las violencias machistas, entiendo que se hace una apelación directa a los agresores y su responsabilidad en la ejecución de sus privilegios. El discurso directo e identificación de los sujetos responsables del mantenimiento de las violencias sexistas deja de tratar este problema estructural en abstracto, lo que señala de forma directa a aquellos que disfrutan de la libertad de los privilegios masculinos.

En segundo lugar, el empleo de técnicas performativas posibilitan sacar a la luz debates que quedan en los márgenes. El uso de símbolos como el pasamontañas, la noche, el negro, los cuales tienen connotación histórica y cultural, nos hacen recordar la historicidad. Sin embargo, a través de la contradicción performativa, esta historicidad se reconvierte o re- escribe, lo cual ofrece una lectura desde los márgenes de esa narrativa histórica dominante. De esta manera, considero que las técnicas performativas de la violencia que emplean las manifestaciones contra las agresiones machistas del MFV, tras un análisis en profundidad, pueden generar o tienen la capacidad de poner sobre la mesa el debate sobre el actual ciclo político vasco de "paz". El imaginario colectivo que relaciona las capuchas a la lucha armada expone que en Euskal Herria, como en muchos otros movimientos de liberación nacionales o coloniales, se ha priorizado un conflicto, el independentista, a los otros múltiples conflictos estructurales tal y como el patriarcado o el racismo, por ejemplo. Por lo tanto, la re- significación de la capucha para la lucha feminista, es decir, para una lucha que no se ha considerado "la primordial" en Euskal Herria, y en concreto en el MLNV, pone sobre la mesa el discurso androcentrista sobre la paz, la cual sólo contempla la paz entre los hombres. 
Este estudio de caso es significativo del potencial político de la violencia performativa en cuanto a abrir nuevos enfoques para profundizar el análisis del impacto y eficacia de la violencia performativa como forma de protesta y herramienta para abrir paso a debates que están en los márgenes. En el caso del presente trabajo, además, ofrece una comprensión más matizada, holística y estructural de la violencia en general, y en relación a la lucha contra la misoginia y las violencias machistas en particular.

Finalmente, destacaría la capacidad movilizadora de reflexión y des-normalización de crear incomodidades e inquietudes. Representaciones o performances que crean incomodidades suscitan cuestionar la normalización y naturalización de normas. Las manifestaciones que he tenido como objeto no han dejado indiferente a nadie. No sólo a aquellas personas apeladas directamente, sino también a las personas que eran invitadas a participar en esta forma de protesta. Es esta capacidad de crear inquietudes de forma multi- direccional una de las interpretaciones más interesantes surgidas a lo largo del análisis.

Dicho de otro modo, subrayaría conceptos como la experimentación, flexibilidad, contradicción, reflexividad y potencial creativo de las manifestaciones que he explorado como los aspectos que crean el potencial para un código ético feminista, así como medios y estrategias efectivas para desmantelar las normas y estándares generizados que sostienen problemas como las violencias machistas, pero también todas las formas de violencia sistémica.

Aunque mi investigación no puede comprobar si las herramientas del amo pueden desmantelar la casa del amo, lo que sí me atrevería a concluir es que desde luego tienen el poder de sacudir sus cimientos, y los cambios y movimientos no pueden ser subestimados en las luchas sociales.

Al hilo de lo cual, identifico una línea de investigación y trabajo feminista futuro interesante: indagar de qué formas algunas mujeres no se sienten a gusto, les incomoda o sienten rechazo hacia la agenciación de técnicas performativas de la violencia. No obstante, mi objetivo está lejos de buscar unanimidad en cuanto a definir, dictar o establecer una única estrategia para hacer frente a las violencias machistas, y además que esta tenga que ser representada a través de violencia simbólica. Pero, considero relevante abrir debate sobre la reticencia que podamos sentir algunas mujeres hacia la idea de generar violencia, no por hacer una apología de la violencia, sino por situar esto en un sistema patriarcal concreto y no vincularlo automáticamente a concepciones de comportamiento individualistas y que esconden normas de género binarias y esencialistas. 


\section{BIBLIOGRAFÍA}

Agra Romero, María Xoxé (2012) Con Armas, Como Armas: La Violencia de las Mujeres, Revista Isegoría. Revista de Filosofía Moral y Política, No. 46, 49-74.

Ahmed, Sarah (2004) “Queer Feelings”, In Cultural Politics of Affect. 144-167.

Alcázar Campos, Ana (2010) La Cuba de verdad. Construcción de alteridades y turismo en la contemporaneidad. Granada: Universidad de Granada.

Alcedo, Miren (2006) Mujeres de ETA: la Cuestión del Género en la Clandestinidad, Mujeres en Red. El Perdiódico Feminista 6.05.2006 [online]. Disponible en: http://www.mujeresenred.net/spip.php?article566

Aretxaga, Begoña (1995) Dirty Protest: Symbolic Overdetermination and Gender in Northern Ireland Ethnic Violence, Ethos, 23 (2), 123-148.

Aretxaga, Begoña (2005) States of Terror. Begoña Aretxaga's Essays edited by Joseba Zulaika. Reno: Center for Basque Studies, University of Nevada.

Aretxaga, Begoña (2009) "Prólogo. La Muerte de Yoyes: Discursos Culturales de Género y Política en el País Vasco". En Garmendia Lasa, Elixabete; Gonzalez Katarain, Glori; GonzalezKatarain, Ana; Garmendia Lasa Juli y Dorronsoro, Juanjo, Yoyes: Desde su Ventana, Irun: Alberdania S.L. 7-35.

Azpiazu Carballo, J. (2014) "Capítulo 6. Análisis crítico del discurso con perspectiva feminista" In Mendia Azkue, I.; Luxán, M.; Legarreta, M.; Guzmán, G.; Zirion, I. \& Azpiazu Carballo, J. (eds.) Otras Formas de (Re)Conocer. Reflexiones, Herramientas y Aplicaciones De La Investigacion Feminista, Hegoa, University of The Basque Country: 111-125.

Banerjee, Sikata (2003) Gender and Nationalism: The Masculinization of Hinduism and Female Political Participation in India. Women's Studies International Forum, 26(2):167179.

Borland, Katherine, (1991) "Chapter 4: "That's not what I said": Interpretive Conflict In Oral Narrative Research". In Gluck, S. B. \& Patai, D. (Eds.) Women's Words: the Feminist Practice of Oral History, New York: Routledge, 63-75.

Butler, Judith y Spivak, Gayatri (2007) Who Singsthe Nation- State? New York, Oxford: Seagull Books.

Butler, Judith (1988) Performative Acts and Gender Constitution: An Essay in Phenomenology and Feminist Theory, Theatre Journal, Vol. 40, No. 4: 519-531.

Butler, Judith (1990) "Subversive Bodily Acts", en Gender Trouble. Feminism and the Subversion of Identity, New York and London: Routledge, 79-142. 
Butler, Judith (2009) Performativity, Precarity and Sexual Politics, AIBR. Revista de Antropología Iberoamericana. Volumen 4, No 3: i-xiii.

Caitlin, Bruce (2015) The Balaclava as Affect Generator: Free Pussy Riot Protests and Transnational Iconicity, Communication and Critical/Cultural Studies, 12:1, 42-62.

Calvo, Rafael Leonisio (2012) "Izquierda abertzale. De la heterogeneidad al monolitismo". Navajas Zubeldia, Carlos e Iturriaga Barco, Diego (eds.): Coetánea. Actas del III Congreso Internacional de Historia de Nuestro Tiempo. Logroño: Universidad de La Rioja: 377-388.

Casquete Badallo, Jesús María (2007a) Eusko gudariak: Un Producto Bilbaíno de la II República. Bidebarrieta: Revista de humanidades y ciencias sociales de Bilbao, №. 18, 2007 (Ejemplar dedicado a: 70 años de la guerra civil : guerra, posguerra y memoria), págs. 283-292.

Casquete Badallo, Jesús María (2007b) Religiones Políticas y Héroes Patrios, Papers: Revista de Sociología, 84: 129-138.

Cortés Baeza, Amapola (2014) EL Giro Estético DeL Pasamontañas: Reflexión a Partir del Caso del Ejército Zapatista de Liberación Nacional (1994 - 2014), Tesis para optar al grado de Licenciada en Artes mención en Teoría e Historia del Arte. Universidad de Chile.

da Fonseca, Alexandre M. (2015) "What does the Balaclava Stand For? Pussy Riot: Just Some Stupid Girls or Punk With Substance?", en Guerra, Paula and Moreira, Tânia (eds) Keep it Simple, Make it Fast! An approach to underground music scenes, Universidad de Letras. Universidad de Porto, 91-103.

Del Valle, Teresa (1985) Mujer vasca. Imagen y realidad, Barcelona: Anthropos.

Del Valle, Teresa (1997) El Género en la Contrucción de la Identidad Nacionalista. Ankulegi. Gizarte Antropologia Aldizkaria 1: 9-22.

Egaña, Iñaki (1996) Diccionario histórico-político de Euskal Herria. Donostia: Txalaparta.

Ellis, Stephen (2003). Violence and history: a response to Thandika Mkandawire, Journal of Modern African Studies 41(3): 457-475.

Epelde Pagola, Edurne; Aranguren Etxarte, Miren y Retolaza Gutierrez, Iratxe (2015) Gure genealogia feministak: Euskal Herriko Mugimendu Feministaren kronika bat. Nafarroa: Emagin Dokumentazio eta Ikerkuntza Zentro Feminista.

Esteban, Mari Luz (2017) Feminismoa eta Politikaren Eraldaketak. Larrabetzu: Susa.

Euskal Herriko Bilgune Feminista (2002) Presentación del EUSKAL HERRIKO BILGUNE FEMINISTA. 
Euskal Herriko Bilgune Feminista (2007) Euskal Herri Feminista Sortzera Goaz!! Euskal Herriko Bilgune Feministaren Barne Hausnarketaren Ondorioak.

Euskal Herriko Bilgune Feminista (2010) Euskal Herriko Bilgune Feministaren Jardun Feminista.

Euskal Herriko Bilgune Feminista (2013) Euskal Herriko Emakumeon Mundu Martxa. Indarkeria Sexistari Aurre Egiteko Protokoloa.

FARRUCAS (2016) ¡Pasa la capucha, hermana!, Pikara Magazine, 12/05/2016 [Availed on 03/2015] Accesible en: https://www.pikaramagazine.com/2016/05/pasa-la-capuchahermanal

Fernandez, James W. (1972) Persuasions and Performances: Of the Beast in Every Body... And the Metaphors of Everyman. Daedalus, 101(1): 39-60.

Fernández Sobrado, José Manuel and Aierdi Urraza, Xabier (1997) Entramado organizativo del movimiento feminista en el país vasco, Reis: Revista Española de Investigaciones Sociológicas, No. 80: 183-201.

Fernandez Soldevilla, Gaizka (2012) Historia de una Heterodoxia Abertzale. ETA Político-Militar, EIA Y Euskadiko Ezkerra (1974-1994). Euskal Herriko Unibertsitatea/ Universidad del País Vasco.

García, Eduardo (2015) Yoyes, Víctima de Terroristas y Machistas, La Nueva España, 17/04/2015, 30.

Ghasarian, Christian (2008) "Por los Caminos de la Etnografía Reflexiva". En Adolfo Colombres (eds.) De la Etnografía a la Antropología Reflexiva: Nuevos Campos, Nuevas Prácticas, Nuevas Apuestas. Buenos Aires: Del Sol, 9-43.

Goikoetxea, Jule (2015) Bakea ez da existitzen, feminismoa bai (I), Klitto! Atari Digitala, 2015/10/08, accesible en: http://www.klitto.eus/bakea-ez-da-existitzen-feminismoa-baiil

Gregorio Gil, Carmen (2006) Contribuciones feministas a problemas epistemológicos de la disciplina antropológica: representación y relaciones de poder, AIBR: Revista de Antropología Iberoamericana, Vol. 1, №. 1: 22-39.

Gregorio Gil, Carmen y Franzé, Adela (2006) "Una mirada desde la antropología social: Diferenciaciones de género y mediaciones culturales en los procesos educativos Género y Currículo". En Rodríguez, Carmen (eds) Aportaciones del género al estudio y práctica del currículo. Madrid. Akal: 77-100.

Guber, Rosana (2001) “Epílogo. El método etnográfico en el texto”. En La Etnografía. Método, Campo y Reflexividad. Bogotá: Grupo Editorial. 121-129. 
Halberstam, Judith (1998) "Introduction to Female Masculinities. Masculinity Without Men”. En Female Masculinity, Duke University Press, 1-42.

Hale, Hannah C. (2012) The Role of Practice in the Development of Military Masculinities, Gender, Work and Organization, Vol. 19 No. 6: 699-722.

Hamilton, Carrie(2007) The Gender Politics of Political Violence: Women Armed Activists in ETA, Feminist Review, 86: 132-148.

Harding, Sandra (1998) ¿Existe un método feminista? En Bartra, E. (Ed.) Debates en torno a una Metodología Feminista, México: Universidad Autónoma Metropolitana: 934.

Hesse- Biber, Sharlenne (2007) "Chapter 1: Feminist Research: Exploring the Interconnections of Epistemology, Methodology and Method". In Hesse-Biber, Sharlenne (Ed.) Handbook of Feminist Research: Theory and Praxis, London: Sage, 126.

Huisman, Kimberly (2008) "Does This Mean You're Not Going to Come Visit Me Anymore?": An Inquiry into an Ethics of Reciprocity and Positionality in Feminist Ethnographic Research, Sociological Inquiry, Vol. 78, No. 3, 372-396.

Lorde, Audre (1963) "The Master's Tools Will Never Dismantle the Master's House", in Moraga, Cherrie y ANzaldúa, Gloria (eds) This Bridge Called My Back: Writings By Radical Women of Color. New York: Kitchen Table Press. 94-101.

Manzi, Yvonne (2014) Performative Violence: Conceptual and Strategic Implications, EInternational Studies. Students. Essays. Disponible en: http://www.eir.info/2014/02/28/performative-violence-conceptual-and-strategic-implications/

Medeak (2014) Violencia y Transfeminismo. Una Mirada Situada. En Solá, Miriam; Urko, Elena (coord.) (2014) Transfeminismos. Epistems, fricciones y flujos. Tafalla: Txalaparta. 73-79.

Mies, Maria (1983) "Chapter 9: Towards a Methodology for Feminist Research". In Bowles, G. \& Klein, R. D. (Eds.) Theories for Women's Studies, London: Routledge \& Kegan Paul, 117-139.

Mies, Maria (1991). “Women's Research or Feminist Research". In Fonow, M.M. \& Cook, J.A. (Eds.) Beyond Methodology. Feminist Scholarship as Lived Research, Bloomington: Indiana University Press, 62-102.

Nagel, Joane (1998) "Masculinity and Nationalism: Gender and Sexuality in the Making of Nations," Ethnic and Racial Studies, 21(2), March 1998: 242-269.

Nagel, Joanne (2003) "Chapter 5: Sex and Nationalism: Sexually Imagined Communities" in Race, Ethnicity, and Sexuality. Oxford University' Press: 140-176. 
Naples, Nancy A. (1996) A feminist revisiting of the insider/outsider debate: The "outsider phenomenon" in rural lowa, Qualitative Sociology, Volume 19, Issue 1, 83-106.

Prozorov, Segei (2014) Pussy Riot and the Politics of Profanation: Parody, Performativity, Veridiction, Political Studies, VOL 62, 766-783.

Raento, Pauliina (1997) Political Mobilisation and Place-Specificity: Radical Nationalist Street Campaigning In The Spanish Basque Country, Space and Polity, 1:2, 191-204. Rhodes, Joel P. (2001) The Voice of Violence. Performative Violence as Protest In the Vietnam Era. Westport, Conn: Praeger.

Rodriguez Lara, Zuriñe (2012) Mujeres Armadas: una Mirada a las Mujeres Armadas a través del Discurso Mediático, sin publicar, Máster en Gobernanza y Estudios Políticos Trabajo de investigación. UPV.

Rodriguez Lara, Zuriñe (2015) Gatazka, Normalizazioa eta Feminismoa, Jakin, 209: 1127.

Rodriguez Lara, Zuriñe y Etxebarrieta Legrand, Oihana (eds) (2016) LISIPE. Borroka armatua eta kartzelak. Susa Literatura.

Roseneil, Shasha (1993) "Chapter 7: Greenham revisited: researching myself and my sisters". In Hobbs, D. and May, T. (Eds.) Interpreting the field: accounts and ethnography, Oxford: Clarendon Press, 177-208.

Saratxo, Mikel y Zabalo, Julen (2013) Jarduera armatuaren amaiera. ETAren erabakirako arrazoiak, Jakin, 197: 11-32.

Spike Peterson, V. (1999) Sexing Political Identities: Nationalism as Heterosexism, International Feminist Journal of Politics, 1(1): 34-65.

Spike Peterson, V. (2013) The Intended and Unintended Queering of States/Nations, Studies in Ethnicity and Nationalism, Vol. 13, No. 1, 57- 68.

Spivak, Gayatri Chakravorty (2014) Preface to Concerning Violence, Film Quarterly, Vol. 68, No. 1.

Sutton, Barbara (2007) Poner el Cuerpo: Women's Embodiment and Political Resistance in Argentina, Latin American Politics and Society, 49:3, 129-162.

Watson, James L (1996). "Fighting with Operas: Processionals Politics and the Spectre of Violence in Rural Hong Kong." In The Politics of Cultural Performance, Parkin, David, Caplan and Fisher eds. Providence: Berghahn, 150-159.

West, Jessica (2005) Feminist IR and the Case of the 'Black Widows': Reproducing Gendered Divisions, Innovations: A Journal of Politics, Volume 5, 1-16.

Yuval-Davis, Nira (1997) Gender \& Nation. London : Sage Publications. 
Zabalo, Julen (1993) Euskal Nazionalismoa eta Nazio Amaiaraldea. Euska Herriko Unibertsitatea/ Universidad del País Vasco.

Zabalo, Julen y Saratxo, Mikel (2015) ETA ceasefire: Armed struggle vs. political practice in Basque nationalism, Ethnicities, Vol. 15(3): 362-384.

Ziga, Itziar (2015) El Feminismo Punk no ha Muerto. Gara 03/09/2015. Accesible en: http://www.naiz.eus/es/hemeroteca/gara/editions/2015-09-03/hemeroteca articles/elfeminismo-punk-no-ha-muerto

Zulaika, Joseba (2009) Terrorism. The Self-Ful Iling Prophecy. Chicago and London: The University of Chicago Press.

- $\quad$ Páginas web, periódicos online y revistas online:

A.d. (2014) Estamos Hartas de Agresiones Sexistas, jel 4 de Julio el Miedo Va a Cambiar de Bando!, Ahotsa, 2014-06-27 Accesible en: http://ahotsa.info/edukia/estamos-hartas-de-agresiones-sexistas-el-4-de-julio-el-miedova-a-cambiar-de-bando

A.d. (2014) Manifestación Nocturna en Iruñea Contra las Agresiones Sexistas, Naiz.info 2014/07/05. Accesible en: http://www.naiz.eus/eu/actualidad/noticia/20140705/manifestacion-nocturna-en-iruneacontra-las-agresiones-sexistas

A.d. (2014) GAUA ETA JAIAK GUREAK DIRA. ERASORIK EZ, ERANTZUNIK GABE!!, Eginklik, Accesible en: http://ekinklik.org/index.php/es/ultimas-coberturas/472-gaua-etajaiak-gureak-dira-erasorik-ez-erantzunik-gabe

A.d. (2015) Un ataque feminista contra los blusas de Vitoria enturbia el final de las fiestas http://misandria.info/f11/ataque-feminista-contra-blusas-de-vitoria-enturbia-final-defiestas-3128/

A.d. (2016) El Movimiento Feminista Prepara Una Manifestación "Histórica" En Vitoria. El Mundo, 01/04/2016. Accesible en: http://www.elmundo.es/paisvasco/2016/04/01/56fe6fabca474154428b45a3.html

Asensio Lozano, Maite (2016) Erantzutea Zilegi Izan Dadin, Argia, apirilak 6. Accesible en:

http://www.berria.eus/paperekoa/1851/002/001/2016-04-

06/erantzutea_zilegi_izan_dadin.htm

Bilgune Feminista (2016) Herri jai feministak, 2016. Pikara Magazine, 09/07/2016. Accesible en:

http://www.pikaramagazine.com/2016/07/herri-jai-feministak-2016/ 
Cañete, Susana (2014) Sanfermines: violencia machista y autodefensa feminista. Argia 17/07/2014 Available in: http://www.pikaramagazine.com/2014/07/sanferminesviolencia-machista-y-autodefensa-feminista/\#

Coordinadora Feminista (2014) Manifestación nocturna 4 de Julio en Iruñea contra las agresiones sexistas. 5/08/2014 Accesible en: http://www.feministas.org/manifestacionnocturna-4-de-julio.html

Coordinadora Feminista (2016) El Miedo Va a Cambiar de Bando. 30 junio 2016. Accesible en: http://www.feministas.org/el-miedo-va-a-cambiar-de-bando.html

Coordinadora Feminista (2016) Feministok Prest! \#ErantzunFeminista. accesible en: http://www.feministas.org/feministok-prest-erantzunfeminista.html

Fernandez, Igone (2012) EHBF: HAMAR URTE ETA HAMAIKA EGITEKO. Gaztezulo, 2012/01/06. Accesible en: https://www.gaztezulo.eus/albisteak/ehbf-hamar-urte-etahamaika-egiteko

Gatón, Ignacio (2015) El colectivo feminista corta el paseíllo de neskak y blusas por una queja de machismo verbal. Gasteiz Hoy, 8 Agosto, 2015. Accesible en: http://www.gasteizhoy.com/el-colectivo-feminista-corta-el-paseillo-de-los-blusas-paraprotestar-por-una-supuesta-agresion-verbal/

Monroy, Maitena (2015) Que la vergüenza cambie de bando. Reflexiones sobre la autodefensa feminista, Pikara Magazine 23/11/2015, Accesible en: http://www.pikaramagazine.com/2015/11/que-la-verguenza-cambie-de-bandoreflexiones-sobre-la-autodefensa-feminista/

Zabala Gonzalez, Begoña (2015) El Miedo Va a Cambiar de Bando. Pikara Magazine. 3/07/2015 http://www.pikaramagazine.com/2015/07/el-miedo-va-a-cambiar-de-bando/ 